WSRC-TR-99-00317

\title{
Qualification of Reillexf HPQ Anion Exchange Resin for Use in SRS Processes
}

\author{
William J. Crooks III \\ Edward A. Kyser III \\ Steven R. Walter \\ Westinghouse Savannah River Company \\ Aiken, SC 29808
}

March 10, 2000 


\section{DISCLAIMER}

This report was prepared as an account of work sponsored by an agency of the United States Government. Neither the United States Government nor any agency thereof, nor any of their employees, makes any warranty, express or implied, or assumes any legal liability or responsibility for the accuracy, completeness, or usefulness of any information, apparatus, product or process disclosed, or represents that its use would not infringe privately owned rights. Reference herein to any specific commercial product, process or service by trade name, trademark, manufacturer, or otherwise does not necessarily constitute or imply its endorsement, recommendation, or favoring by the United States Government or any agency thereof. The views and opinions of authors expressed herein do not necessarily state or reflect those of the United States Government or any agency thereof.

This report has been reproduced directly from the best available copy.

Available for sale to the public, in paper, from: U.S. Department of Commerce, National Technical Information Service, 5285 Port Royal Road, Springfield, VA 22161

phone: (800) 553-6847

fax: (703) 605-6900

email: orders@ntis.fedworld.gov

online ordering: http://www.ntis.gov/ordering.htm

Available electronically at http://www.doe.gov/bridge

Available for a processing fee to U.S. Department of Energy and its contractors, in paper, from: U.S. Department of Energy, Office of Scientific and Technical Information,

P.O. Box 62, Oak Ridge, TN 37831-0062

phone: (865)576-8401

fax: $(865) 576-5728$

email: reports@adonis.osti.gov 


\section{EXECUTIVE SUMMARY}

As part of the resin qualification process for HB Line Phase II, the thermal stability of Reillexf HPQ anion exchange resin in nitric acid solutions was evaluated using the Reactive System Screening Tool (RSST). The RSST allows for efficient screening of runaway reactions as a function of temperature. Resin qualification is based on a favorable comparison of the RSST reaction profiles of Reillexf HPQ to Ionacf A-641, a resin previously qualified for use in HB Line.

Resin/nitric acid mixtures were heated in the RSST and the temperature-pressure responses were determined as a function of resin type, nitric acid concentration, cerium(IV) loading, and damage caused by previous irradiation of the resin. Above $100{ }^{\circ} \mathrm{C}$, Reillexf HPQ, irradiated Reillexf HPQ, and Ionacf A-641 showed similar reaction profiles as a function of temperature. Reillexf HPQ showed no obvious inertness to chemical degradation relative to Ionacf A-641. Below $100{ }^{\circ} \mathrm{C}$, a low intensity, low-temperature exotherm $\left(80{ }^{\circ} \mathrm{C}, 2{ }^{\circ} \mathrm{C} / \mathrm{min}\right)$ was observed only for Reillexf HPQ, suggesting the presence of a small amount of easily-oxidizable material.

A detailed study of the low-temperature exothermic reaction of Reillexf HPQ and nitric acid identified nitric oxide (NO) and carbon dioxide $\left(\mathrm{CO}_{2}\right)$ as gaseous reaction products. In addition, spectroscopic analysis identified a carbonyl group in the solid resin reaction product, suggesting the presence of a carboxylic acid. This product characterization suggests the low-temperature exotherm is due to the oxidation of the ethylbenzene pendant groups of the Reillexf $\mathrm{HPQ}$, forming $\mathrm{NO}, \mathrm{CO}_{2}$ and a benzoic acid pendant group. To evaluate this possibility, the nitric acid reaction with diethylbenzene as a model compound was tested in the RSST. Indeed, the diethylbenzene- 8 molar nitric acid reaction showed a low-temperature exotherm, and generated $\mathrm{NO}, \mathrm{CO}_{2}$, and a mixture of mono- and dicarboxylic acids as reaction products. Furthermore, literature precedents have reported the oxidation of ethylbenzene with various oxidizing agents.

For Reillexf HPQ, irradiated Reillexf HPQ, and Ionacf A-641 resins, the time to maximum rate generally decreased as nitric acid concentration increased. For Reillexf HPQ, the higher nitrate concentration tests (Ce(IV)/8M $\mathrm{HNO}_{3}$ and $12 \mathrm{M}$ $\mathrm{HNO}_{3}$ ) showed an overlap between the low and high temperature exotherms, leading to a concern that the lower temperature reaction may initiate the higher temperature reaction. However, long term isothermal resin tests at $100{ }^{\circ} \mathrm{C}$ in the RSST did not cause the high temperature runaway reaction until the resin went dry. When in contact with solution, the energy released from the low-temperature exothermic reaction is not sufficient to activate the high-temperature reaction. The more important issue with the low temperature exotherm is gas evolution. Pressurization in the ion exchange column may force liquid out of the column or lead to over-pressurization.

The RSST data was used to estimate the maximum volume and rate of gas evolution. This calculation of gas volumes and gas generation rates is based on the adiabatic temperature rise during the RSST test. Assuming the low temperature exotherm is due to ethylbenzene oxidization by nitric acid to give $\mathrm{NO}, \mathrm{CO}_{2}$, and benzoic acid as the 
products, the calculated maximum volume of gases generated from a 20-liter column at $80{ }^{\circ} \mathrm{C}$ is about $53 \mathrm{~L} \pm 23$ and the average gas generation rate of $2.3 \mathrm{~L} / \mathrm{min} \pm 1.5$.

In contrast to the Reillexf HPQ tests, Ionacf A-641 and for irradiated Reillexf HPQ showed no increase in reactivity in the presence of cerium(IV). Neither Ionacf A-641 nor irradiated Reillexf HPQ exhibit the low-temperature exotherm under any conditions. This absence of the low temperature exotherm suggests that the small amount of easily oxidized material is not present in Ionacf A-641 and is destroyed during the irradiation of Reillexf HPQ. Therefore, the radioactive decay on a plutonium-loaded column of Reillexf HPQ may also initiate the oxidation of the easily-oxidized material as a function of dose rate, leading to gas generation and pressurization in the ion exchange column.

Maintaining the resin bed temperature below $70{ }^{\circ} \mathrm{C}$, the low temperature exothermic reaction between nitric acid and Reillexf HPQ can be minimized. Operation at lower temperatures will ensure a greater margin of safety. However, irradiation from plutonium loaded on the resin may also cause the oxidation of the easily oxidized component. The relationship between radiation dose and off-gas volume, composition, and generation rate was not studied.

A nitric acid digestion pretreatment was developed that eliminated the low-temperature exothermic reaction without destroying the bead size or shape. The performance testing of this treated resin showed no loss of performance, and is described in an another report. 


\section{Table of Contents}

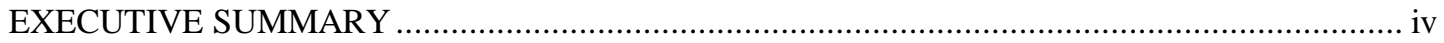

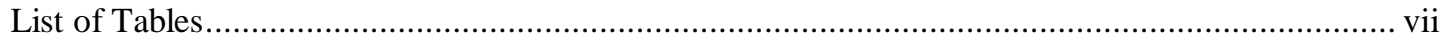

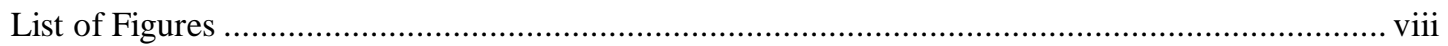

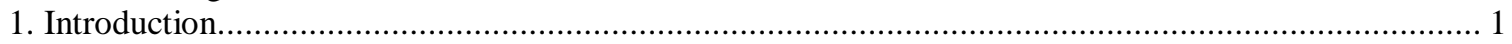

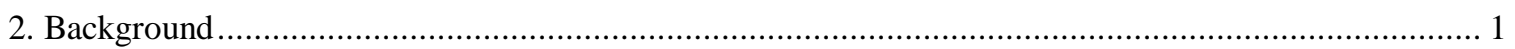

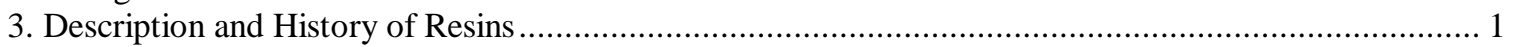

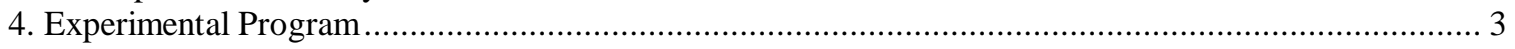

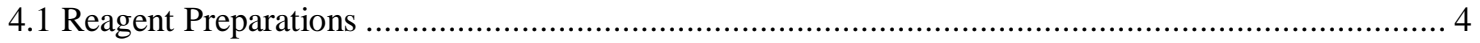

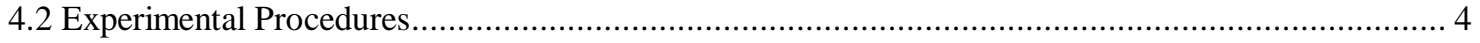

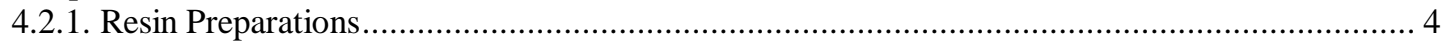

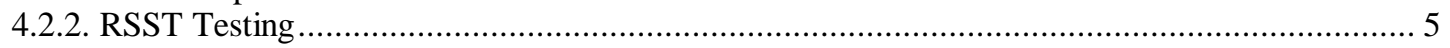

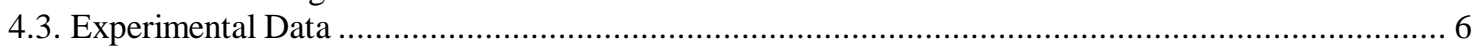

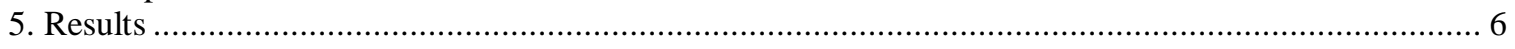

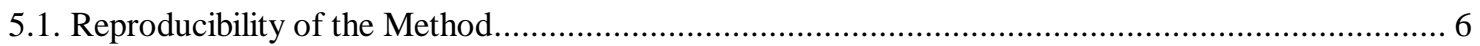

5.2. Pressure Dependency of the Resin/Nitric Acid Reactions........................................................... 7

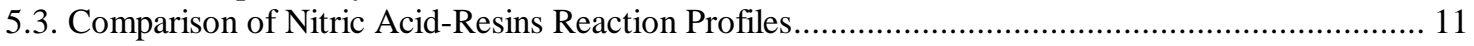

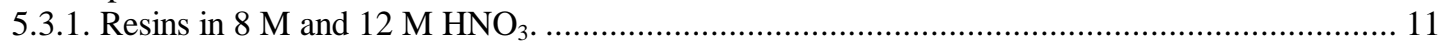

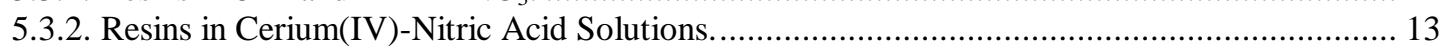

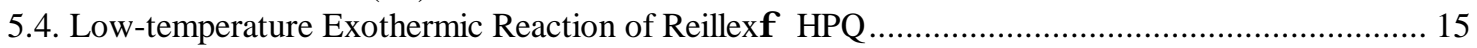

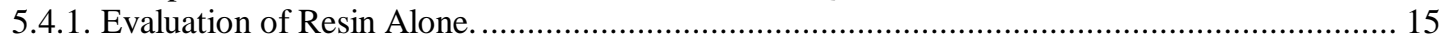

5.4.2. Pre-Treatments to Remove Residual Chemicals................................................................. 15

5.4.3. Nitric Acid Reactions of Methanol and Methyl Benzoate. .................................................... 16

5.4.4. Evaluation of the Reactivity of Reillexf HPQ Resin Components. ..................................... 16

5.4.5. Estimation of the Volume of Gas Generated and Average Gas Generation Rate in a 20-Liter

Column of Reillexf HPQ Resin and 8 Molar Nitric Acid................................................................ 17

5.4.6. Pre-treatment of Reillexf HPQ to Eliminate the Low-temperature Exothermic Reaction........ 19

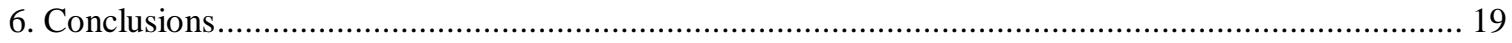

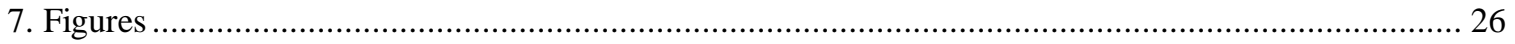




\section{List of Tables}

Table 1. Resin Tests Performed in the RSST Calorimeter...................................................................... 8

Table 2. Low-Temperature Exotherm Characterization of the Reaction of Reillexf $\mathrm{HPQ}$ and $8 \mathrm{M} \mathrm{HNO}_{3}$

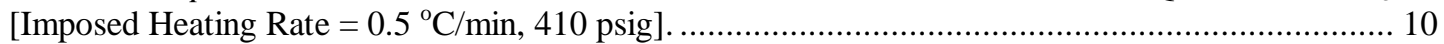

Table 3. High-Temperature Exotherm Characterization of the Reaction of Reillexf $\mathrm{HPQ}$ and $8 \mathrm{M} \mathrm{HNO}_{3}$

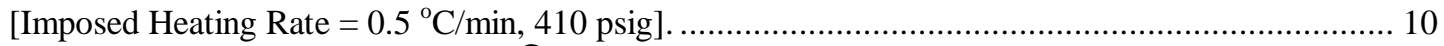

Table 4. Effect of Pressure on the Reillexf HPQ and Nitric Acid Reaction ......................................... 10

Table 5. Characterization of the Reaction of Ionacf A-641 and Nitric Acid Solutions [Imposed Heating Rate $\left.=0.5^{\circ} \mathrm{C} / \mathrm{min}, 400 \mathrm{psi}\right]$.

Table 6. Characterization of the Reaction of Reillexf HPQ and Nitric Acid Solutions [Imposed Heating

Rate $\left.=0.5^{\circ} \mathrm{C} / \mathrm{min}, 400 \mathrm{psi}\right]$.

Table 7. Characterization of the Reaction of Irradiated Reillexf HPQ and Nitric Acid Solutions

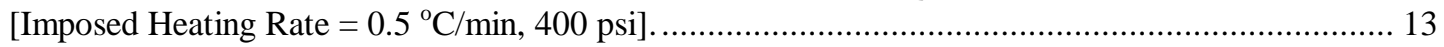

Table 8. Calculation of the thermal inertia, $\Phi$, for Reillexf HPQ and 8 molar nitric acid mixtures........... 21

Table 9. Calculation of the enthalpy of reaction $\left(\Delta \mathrm{H}_{\mathrm{rxn}, 1}\right)$ for equation $1\left(\mathrm{NO}_{2}\right.$ as product $)$....................... 22

Table 10. Calculation of the enthalpy of reaction $\left(\Delta \mathrm{H}_{\mathrm{rxn}, 2}\right)$ for equation 2 (NO as product) ...................... 22

Table 11. Calculation of the mass of ethylbenzene reacted $\left(\mathrm{m}_{\mathrm{EB}}\right)$ in 20 liters of Reillexf HPQ as a result of

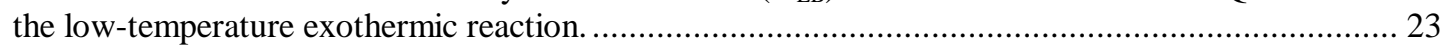

Table 12. Results of the calculation of the mass of ethylbenzene reacted $\left(\mathrm{m}_{\mathrm{EB}}\right)$ according to equation 1 $\left(\mathrm{NO}_{2}\right.$ as product).... 24

Table 13. Results of the calculation of the mass of ethylbenzene reacted $\left(\mathrm{m}_{\mathrm{EB}}\right)$ according to equation 2 (NO as product)

Table 14. Estimation of the volume of gas generated and average gas generation rate in a 20-liter column of Reillexf HPQ and 8 molar nitric acid. 


\section{List of Figures}

Figure 1. RSST Reproducibility Tests of Reillexf $\mathrm{HPQ}$ in $8 \mathrm{M} \mathrm{HNO}_{3}$ :

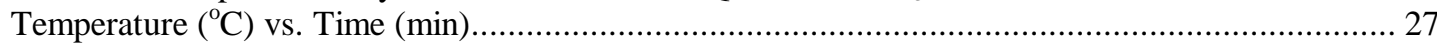

Figure 2. RSST Reproducibility Tests of Reillexf $\mathrm{HPQ}$ in $8 \mathrm{M} \mathrm{HNO}_{3}$ : Pressure (psig) vs. Time (min)... 27

Figure 3. RSST Reproducibility Tests of Reillexf $\mathrm{HPQ}$ in $8 \mathrm{M} \mathrm{HNO}_{3}$ :

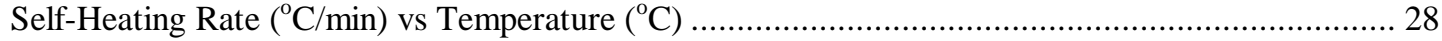

Figure 4. RSST Reproducibility Tests of Reillexf $\mathrm{HPQ}$ in $8 \mathrm{M} \mathrm{HNO}_{3}$ :

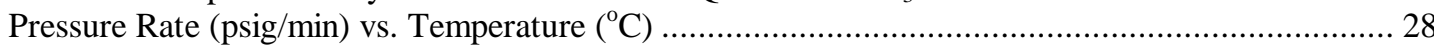

Figure 5. RSST Backpressure Variation Test of Reillexf Resin in $8 \mathrm{M} \mathrm{HNO}_{3}$ :

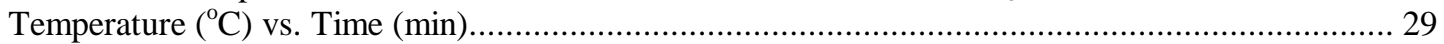

Figure 6. RSST Backpressure Variation Test of Reillexf Resin in $8 \mathrm{M} \mathrm{HNO}_{3}$ :

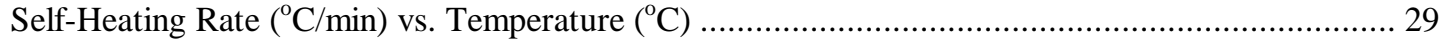

Figure 7. RSST Resin Comparison Tests in $8 \mathrm{M} \mathrm{HNO}_{3}$ : Temperature $\left({ }^{\circ} \mathrm{C}\right)$ vs. Time (min) ....................... 30

Figure 8. RSST Resin Comparison Tests in $8 \mathrm{M} \mathrm{HNO}_{3}$ : Pressure (psig) vs. Time (min) ........................... 30

Figure 9. RSST Resin Comparison Tests in $8 \mathrm{M} \mathrm{HNO}_{3}$ :

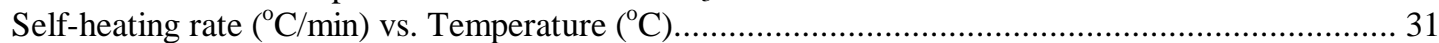

Figure 10. RSST Resin Comparison Tests in $8 \mathrm{M} \mathrm{HNO}_{3}$ : Pressure Rate (psi/min) vs. Temperature $\left({ }^{\circ} \mathrm{C}\right) . .31$

Figure 11. RSST Resin Comparison Tests in $12 \mathrm{M} \mathrm{HNO}_{3}$ : Temperature $\left({ }^{\circ} \mathrm{C}\right)$ vs. Time (min) ................... 32

Figure 12. RSST Resin Comparison Tests in $12 \mathrm{M} \mathrm{HNO}_{3}$ : Pressure (psig) vs. Time (min) ........................ 32

Figure 13. RSST Resin Comparison Tests in $12 \mathrm{M} \mathrm{HNO}_{3}$ :

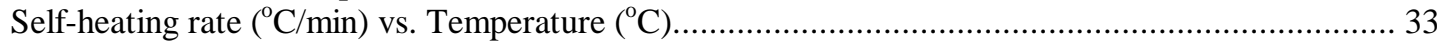

Figure 14. RSST Resin Comparison Tests in $12 \mathrm{M} \mathrm{HNO}_{3}$ :

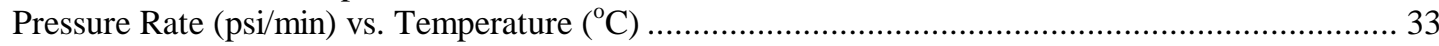

Figure 15. RSST Test of the Effect of Ce(IV) on Ionacf A-641 in $8 \mathrm{M} \mathrm{HNO}_{3}$ :

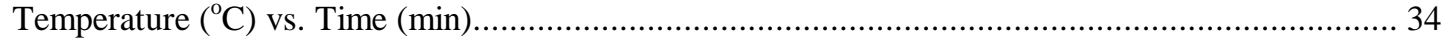

Figure 16. RSST Test of the Effect of Ce(IV) on Ionacf A-641 in $8 \mathrm{M} \mathrm{HNO}_{3}$ :

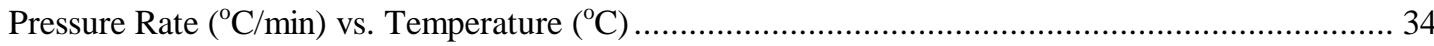

Figure 17. RSST Test of the Effect of $\mathrm{Ce}(\mathrm{IV})$ on Ionacf $\mathrm{A}-641$ in $8 \mathrm{M} \mathrm{HNO}_{3}$ :

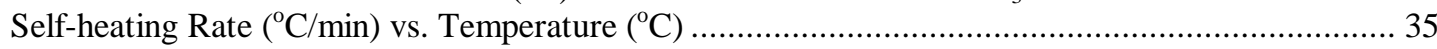

Figure 18. RSST Test of the Effect of Ce(IV) Test on Ionacf A-641 in $12 \mathrm{M} \mathrm{HNO}_{3}$ :

Temperature $\left({ }^{\circ} \mathrm{C}\right)$ vs. Time $(\mathrm{min})$.

Figure 19. RSST Test of the Effect of Ce(IV) on Ionacf A-641 in $12 \mathrm{M} \mathrm{HNO}_{3}$ :

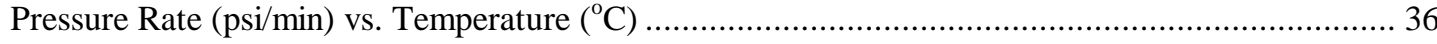

Figure 20. RSST Test of the Effect of Ce(IV) on Ionacf A-641 in $12 \mathrm{M} \mathrm{HNO}_{3}$ :

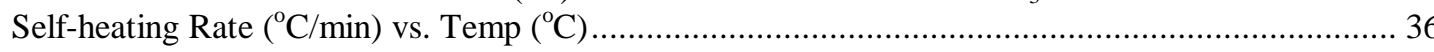

Figure 21. RSST Test of the Effect of Ce(IV) on Reillexf $\mathrm{HPQ}$ in $8 \mathrm{M} \mathrm{HNO}_{3}$ :

Temperature $\left({ }^{\circ} \mathrm{C}\right)$ vs. Time ( $\left.\mathrm{min}\right)$

Figure 22. RSST Test of the Effect of Ce(IV) on Reillexf Resin in $8 \mathrm{M} \mathrm{HNO}_{3}$ :

Pressure Rate (psi/min) vs. Temperature $\left({ }^{\circ} \mathrm{C}\right)$

Figure 23. RSST Test of the Effect of Ce(IV) on Reillexf $\mathrm{HPQ}$ in $8 \mathrm{M} \mathrm{HNO}_{3}$ :

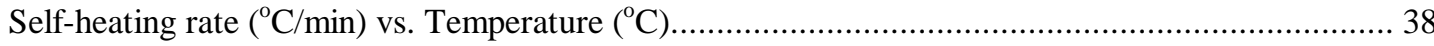

Figure 24. RSST Test of the Effect of Ce(IV) on Reillexf $\mathrm{HPQ}$ in $12 \mathrm{M} \mathrm{HNO}_{3}$ :

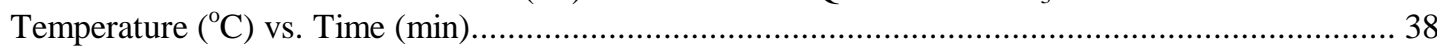

Figure 25. RSST Tests of the Effect of Ce(IV) on Reillexf $\mathrm{HPQ}$ in $12 \mathrm{M} \mathrm{HNO}_{3}$ :

Pressure Rate (psi/min) vs. Temperature $\left({ }^{\circ} \mathrm{C}\right)$

Figure 26. RSST Testsof the Effect of Ce(IV) on Reillexf $\mathrm{HPQ}$ in $12 \mathrm{M} \mathrm{HNO}_{3}$ :

Self-heating Rate $\left({ }^{\circ} \mathrm{C} / \mathrm{min}\right)$ vs. Temperature $\left({ }^{\circ} \mathrm{C}\right)$

Figure 27. RSST Test of the Effect of Ce(IV) on Irradiated Reillexf HPQ in $8 \mathrm{M} \mathrm{HNO}_{3}$ :

Temperature $\left({ }^{\circ} \mathrm{C}\right)$ vs. Time $(\mathrm{min})$.

Figure 28. RSST Test of the Effect of Ce(IV) on Irradiated Reillexf HPQ in $8 \mathrm{M} \mathrm{HNO}_{3}$ :

Pressure Rate (psi/min) vs. Temperature $\left({ }^{\circ} \mathrm{C}\right)$

Figure 29. RSST Test of the Effect of Ce(IV) on Irradiated Reillexf $\mathrm{HPQ}$ in $8 \mathrm{M} \mathrm{HNO}_{3}$ :

Self Heating Rate $\left({ }^{\circ} \mathrm{C} / \mathrm{min}\right)$ vs. Temperature $\left({ }^{\circ} \mathrm{C}\right)$. 41 
Figure 30. RSST Test of the Effect of Ce(IV) on Irradidated Reillexf $\mathrm{HPQ}$ in $12 \mathrm{M} \mathrm{HNO}_{3}$ :

Temperature $\left({ }^{\circ} \mathrm{C}\right)$ vs. Time ( $\left.\mathrm{min}\right)$ 41

Figure 31. RSST Test of the Effect of Ce(IV) on Irradiated Reillexf in $12 \mathrm{M} \mathrm{HNO}_{3}$ :

Presure Rate $\left({ }^{\circ} \mathrm{C} / \mathrm{min}\right)$ vs. Temperature $\left({ }^{\circ} \mathrm{C}\right)$

Figure 32. RSST Test of the Effect of Ce(IV) on Irradiated Reillexf in $12 \mathrm{M} \mathrm{HNO}_{3}$ :

Self-heating Rate $\left({ }^{\circ} \mathrm{C} / \mathrm{min}\right)$ vs. Temperature $\left({ }^{\circ} \mathrm{C}\right)$

Figure 33. RSST Comparison Test of Resins in $8 \mathrm{M} \mathrm{HNO}_{3}$ at $100{ }^{\circ} \mathrm{C}$ :

Temperature $\left({ }^{\circ} \mathrm{C}\right)$ vs Time $(\mathrm{min})$

Figure 34. RSST Resin Comparison Test in $8 \mathrm{M} \mathrm{HNO}_{3}$ with $24 \mathrm{~g} / \mathrm{L} \mathrm{Ce}$ (IV):

Self-heating Rate $\left({ }^{\circ} \mathrm{C} / \mathrm{min}\right)$ vs. Temperature $\left({ }^{\circ} \mathrm{C}\right)$

Figure 35. RSST Resin Comparison Test in $12 \mathrm{M} \mathrm{HNO}_{3}, 24 \mathrm{~g} / \mathrm{L} \mathrm{Ce}$ (IV):

Self-heating Rate $\left({ }^{\circ} \mathrm{C} / \mathrm{min}\right)$ vs. Temperature $\left({ }^{\circ} \mathrm{C}\right)$

Figure 36. RSST Comparison Tests of Reillexf $\mathrm{HPQ}$ Resin in $8 \mathrm{M} \mathrm{HNO}_{3}$ and in Pump Oil:

Self-Heating Rate $\left({ }^{\circ} \mathrm{C} / \mathrm{min}\right)$ vs. Temperature $\left({ }^{\circ} \mathrm{C}\right)$.

Figure 37. RSST Tests of Wash-Treated Reillexf $\mathrm{HPQ}$ in $8 \mathrm{M} \mathrm{HNO}_{3}$ :

Self-Heating Rate $\left({ }^{\circ} \mathrm{C} / \mathrm{min}\right)$ vs. Temperature $\left({ }^{\circ} \mathrm{C}\right)$

Figure 38. RSST Tests of $12 \mathrm{M} \mathrm{HNO}_{3}$-Treated Reillexf $\mathrm{HPQ}$ in $8 \mathrm{M} \mathrm{HNO}_{3}$ :

Self-heating Rate $\left({ }^{\circ} \mathrm{C} / \mathrm{min}\right)$ vs. Temperature $\left({ }^{\circ} \mathrm{C}\right)$

Figure 39. RSST Test of $12 \mathrm{M} \mathrm{HNO}_{3}$-Treated Reillexf $\mathrm{HPQ}$ in $8 \mathrm{M} \mathrm{HNO}_{3}$ :

Self-heating Rate $\left({ }^{\circ} \mathrm{C} / \mathrm{min}\right)$ vs. Temperature $\left({ }^{\circ} \mathrm{C}\right)$

Figure 40. RSST Tests of Reillexf HPQ in $8 \mathrm{M} \mathrm{HNO}_{3}$ Spiked with $\mathrm{MeOH}$ :

Self-Heating Rate $\left({ }^{\circ} \mathrm{C} / \mathrm{min}\right)$ vs. Temperature $\left({ }^{\circ} \mathrm{C}\right)$

Figure 41. RSST Test of Reillexf HPQ in $8 \mathrm{M} \mathrm{HNO}_{3}$ Spiked with Methyl Benzoate:

Self-heating Rate $\left({ }^{\circ} \mathrm{C} / \mathrm{min}\right)$ vs. Temperature $\left({ }^{\circ} \mathrm{C}\right)$

Figure 42. RSST Test of $8 \mathrm{M} \mathrm{HNO}_{3}$ Spiked with Styrene (no resin):

Self-heating Rate $\left({ }^{\circ} \mathrm{C} / \mathrm{min}\right)$ vs. Temperature $\left({ }^{\circ} \mathrm{C}\right)$

Figure 43. RSST Test of $8 \mathrm{M} \mathrm{HNO}_{3}$ Spiked with Diethylbenzene (no resin):

Self-heating Rate $\left({ }^{\circ} \mathrm{C} / \mathrm{min}\right)$ vs. Temperature $\left({ }^{\circ} \mathrm{C}\right)$

Figure 44. RSST Tests of $8 \mathrm{M} \mathrm{HNO}_{3}$-Treated Reillexf $\mathrm{HPQ}$ in $8 \mathrm{M} \mathrm{HNO}_{3}$ :

Self-heating Rate $\left({ }^{\circ} \mathrm{C} / \mathrm{min}\right)$ vs. Temperature $\left({ }^{\circ} \mathrm{C}\right)$ 48

Figure 45. RSST Tests of $8 \mathrm{M} \mathrm{HNO}_{3}$-Treated Reillexf $\mathrm{HPQ}$ in $8 \mathrm{M} \mathrm{HNO}_{3}$ :

Pressure Rate (psi/min) vs. Temperature $\left({ }^{\circ} \mathrm{C}\right)$

Figure 46. Particle Size Distribution of Reillexf HPQ: Untreated vs. $8 \mathrm{M} \mathrm{HNO}_{3}$-Treated (45 min) 


\section{Introduction}

The Phase II portion of the HB-Line facility was built in the early 1980's to process plutonium and neptunium from nitric acid solutions into oxide suitable for storage in a vault. Although the other portions of HB-Line were started up in the mid 1980's and have operated since that time, the anion exchange and precipitation processes in Phase II were never started up. As part of the material stabilization efforts, Phase II is currently being started up. A new anion exchange resin is needed because the resins that were proposed for use 10 years ago are limited by performance characteristics, disposal requirements, or are no longer commercially available. SRTC is responsible for qualifying all resins prior to their use in Nuclear Materials Stabilization and Storage (NMSS) processes. Qualification consists of both process suitability and thermal stability with nitric acid. This report describes the thermal stability qualification of Reillexf HPQ, the new resin proposed for processing plutonium and neptunium in the HB Line facility.

\section{Background}

Incidents involving undesirable self-accelerated exothermic reactions between organic resins and nitric acid solutions have been well documented. ${ }^{1,2,3,4}$ The motive for studying resins and nitric acid mixtures under upset conditions is to establish a margin of safety during plant process operation. The thermal stability qualification of Reillexf HPQ is based on a favorable comparison of thermal effects with Ionacf A-641, one of the resins that was used previously. This qualification process compares the thermal effects resulting from the reaction of nitric acid solutions with Reillexf HPQ $\left(\mathrm{NO}_{3}{ }^{-}\right.$form) and Ionacf A-641 ( $\mathrm{NO}_{3}{ }^{-}$form), respectively. Using a Reactive System Screening Tool $^{5}$ (RSST), the thermal responses to various upset conditions were determined and compared as a function of nitric acid concentration, cerium (IV) loading (as a simulant for plutonium (IV)), and damage caused by previous irradiation of the resin.

\section{Description and History of Resins}

Ionacf A-641 is a robust strong-base macroporous anion exchange resin $\mathbf{1}$, sold by Sybron Chemicals Inc. It is composed of a cross-linked styrene-divinylbenzene polymer

\footnotetext{
${ }^{1}$ H.T. Fullam, G. Jansen, Jr. and W.J. Van Slyke, Thermal Instabilities in Anion Exchange Processing, Conference on Ion Exchange in the Process Industry. Society of Chemical Industry, London, July 16-18, 1969.

${ }^{2}$ F.W. Miles, "Ion-Exchange-Resin Failures in Processing Actinides, Nuclear Safety, 1968, 9, 394-406.

${ }^{3}$ D.C. Bartholomew, E.J. Kosiancic, B.J. McMurray, D.D. Wodrich and W.M. Harty, Explosion of Ion Exchange Resin in Americium Recovery Service, Hanford Plant, August 30, 1976. Report, Atlantic Richfield Hanford Co., Richland, WA, 1976.

${ }^{4}$ P.G. Rhoades, P.E. Ruhter, M.W. Shupe, R.E. Gerton, Investigations of the Chemical Explosion of an Ion Exchange Resin Column and Resulting Contamination of Personnel in the 242-Z Building, August 30, 1976. Report, Energy Research and Development Agency, Richland Operations Office, Richland, WA, 1976.

${ }^{5}$ Manufactured by Fauske and Associates, Inc., 16W070 West $83^{\text {rd }}$ Street, Burr Ridge, IL, 60521
} 


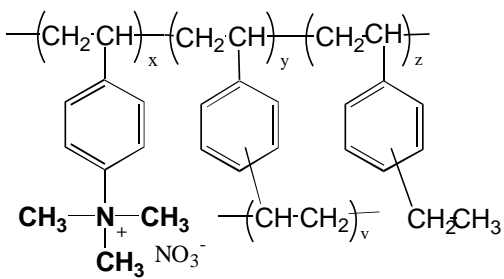

1

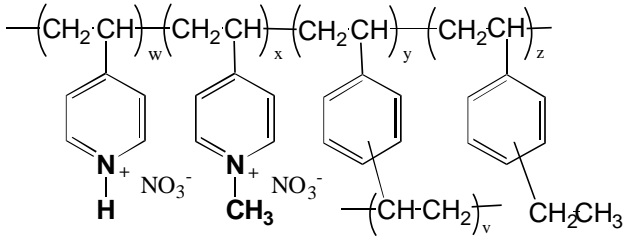

2

backbone structure with a high concentration of quaternary amine exchange sites for anions, $-\left[\mathrm{N}\left(\mathrm{CH}_{3}\right)_{3}\right]^{+}$. This polystyrene-based anion exchange resin has excellent performance characteristics, and mechanical and chemical stability. While this resin has been used in the nuclear industry for many years, it is known to undergo a runaway reaction in hot nitric acid solutions and suffers from loss of performance due to radiological damage.

Reillexf HPQ is also a strong-base macroporous anion exchange resin $\mathbf{2}$, and is sold by Reilly Industries Incorporated. It is composed of a copolymer backbone of 1-methyl-4vinylpyridine (70\%) and a divinylbenzene mixture (30\%). Approximately, 63\% of the amine sites are methylated, forming pyridinium cations, which function as the principal anionic exchange sites. Unquaternarized amines protonate in concentrated nitric acid solutions, also resulting in anionic exchange sites. During the polymeric resin synthesis, the "divinylbenzene mixture" reactant is actually composed of $80 \%$ divinylbenzene positional isomers and $20 \%$ ethylvinylbenzene positional isomers.

Reillexf HPQ was developed as a result of collaboration between Los Alamos National Laboratory and Reilly Industries, Inc. in an effort to increase the safety and process efficiency during the recovery and purification of plutonium. ${ }^{6}$ The merits of a vinylpyridine-based resin were first identified in the 1950's. A 1977 report showed polyvinylpyridine-based anion exchange resins (Permutitf) had excellent performance characteristics, in addition to resistance to both chemical attack and radiological damage. ${ }^{7}$ Marston predicted that the most reactive functional group on the vinylpyridine and vinylstyrene-based resins are the aromatic rings. Due to the greater electron deficiency of the pyridine aromatic ring relative to the benzene aromatic ring, it is expected that the polyvinylpyridine-based resin will be more resistant to electrophilic aromatic substitution relative to the vinylstyrene aromatic ring. Although resin exposure to typical nitric acid process solutions and conditions does not favor nitration of aromatic rings or the formation of highly energetic compounds.

In concentrated nitric acid solutions ( $>6$ molar), plutonium (IV) is complexed by six nitrates to form the anionic complex, $\mathrm{Pu}\left(\mathrm{NO}_{3}\right)_{6}{ }^{2-}$. Ion exchange resins which are

\footnotetext{
${ }^{6}$ S. Frederic Marsh, "Evaluation of a New Macroporous Polyvinylpyridine Resin for Processing Plutonium Using Nitrate Anion Exchange", April 1989, LA-11490

7 T.E. Gangwer, M. Goldstein, K.K.K.S. Phillay, "Radiation Effects on Ion Exchange Materials"

Bookhaven National Laboratory report, BNL-50781 (1977), p. 88.
} 
selective for $\mathrm{Pu}\left(\mathrm{NO}_{3}\right)_{6}{ }^{2-}$ are polymers that typically contain trialkylammonium nitrates, $\mathrm{NR}_{3}{ }^{+} \mathrm{NO}_{3}{ }^{-}$. For example, the anion exchange reaction between a Reillexf HPQ binding site 3 and $\mathrm{Pu}\left(\mathrm{NO}_{3}\right)_{6}{ }^{2-} \mathbf{4}$ yields the stronger resin/ $\mathrm{Pu}\left(\mathrm{NO}_{3}\right)_{6}$ complex $\mathbf{5}$. The high

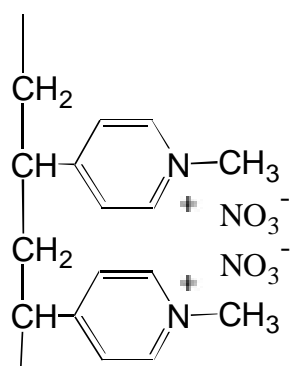

3

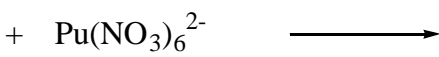

4

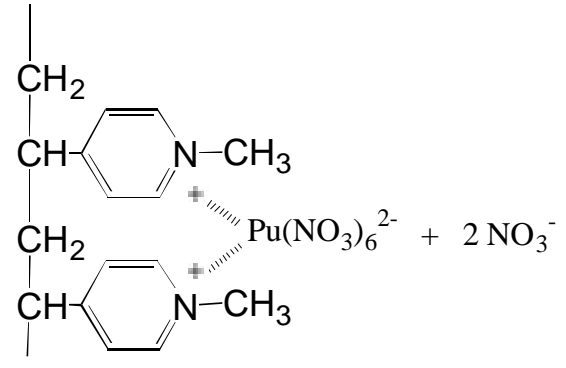

5

selectivity of this resin for plutonium (IV) originates from the uniqueness of the metal anionic complex, and there are few anionic metal complexes that can compete for these cationic binding sites.

Chemical composition and structure of a resin will control the performance characteristics, requirements for disposal, and thermochemical stability. Resins differ in the type of polymeric backbone, the type and concentration of functional groups, the extent of cross-linking, and the overall three-dimensional structure.

\section{Experimental Program}

The RSST was used to characterize the thermal effects of the runaway reactions between solid organic resins and nitric acid solutions. The RSST is a nearly-adiabatic calorimeter that heats an open, well-insulated $10-\mathrm{mL}$ test cell within a sealed $350-\mathrm{mL}$ Parr bomb. In a typical test, the Parr bomb is pressurized to minimize the endothermic process of evaporation of solvent (i.e. loss of oxidant), and the test cell mixture is stirred and heated at a constant rate. The test cell mixture and the Parr bomb are monitored for temperature and pressure, respectively. The pressure-temperature data are processed to generate plots of temperature vs. time, pressure vs. time, self-heating rate vs. temperature, rate of pressure change vs. temperature, and pressure vs. temperature.

The RSST calorimeter allows for efficient screening of runaway reactions as a function of temperature. The reaction of Reillexf HPQ, Ionacf A-641 and irradiated Reillexf HPQf anion exchange resins (all in nitrate form) with nitric acid were compared in the RSST. The thermal effects were evaluated as a function of nitric acid concentration, cerium (IV) loading (as a simulant for plutonium (IV)), and damage caused by previous irradiation of the resin. Much of this work focused on the lowtemperature exothermic reaction observed for Reillexf HPQ-nitric acid mixtures. Offgases associated with this low-temperature exotherm were identified by gas chromatograph-mass spectroscopy (GC-MS), the final nitric acid concentration was determined by titration, and the solid resin residue was characterized by Fourier transform infrared (FTIR) spectroscopy. In addition, the product nitric acid solution was 
analyzed by a solvent extraction volatile organic method to search for soluble resin degradation fragments.

\subsection{Reagent Preparations}

All chemicals used in this study were reagent grade and used without additional purification except where noted. Nitric acid solutions ( $8 \mathrm{M}$ and $12 \mathrm{M}$ with and without dissolved cerium (IV)) were prepared from dilutions of stock nitric acid (69.7\%, purchased from Fisher Scientific, Inc.) and ceric ammonium nitrate (99.6\%, Fisher Laboratory Company, Lot Number 523930). Typical feed solutions for plutonium purification by anion exchange are $5 \mathrm{~g} \mathrm{Pu} / \mathrm{L}$ in 8 molar nitric acid. A fully-loaded column of Reillexf HPQ may be approximately $40 \mathrm{~g} \mathrm{Pu} / \mathrm{L}$ or $0.174 \mathrm{M}$. In concentrated nitric acid solutions, cerium (IV) and plutonium (IV) form analogous hexanitrate anionic complexes, $\mathrm{M}\left(\mathrm{NO}_{3}\right)_{6}{ }^{2-}$, where $\mathrm{M}=$ cerium (IV) or plutonium (IV). In this study, $0.174 \mathrm{M}$ cerium (IV) $(24 \mathrm{~g} / \mathrm{L})$ solutions were prepared as a nonradioactive surrogate for plutonium (IV).

Ionacf A-641 (chloride form) was purchased from Sybron Chemicals Inc., Birmingham, New Jersey. Two batches of Reillexf HPQ (chloride forms: 1995 Lot Number 50224AE and 1998 Lot Number 80302MA) were purchased from Reilly Industries. The 1995 product had a brown color and the 1998 product had a white color. In order to increase the performance characteristics, the 1998 process increased the amount of methylated amine sites. To achieve this, we speculate that the 1998 process may have required higher reaction temperature and longer reaction times than the 1995 process. Except where noted, the 1998 product was used in all experiments. Irradiated Reillexf HPQ (chloride form) was prepared by exposing Reillexf HPQ (chloride form: 1998 Lot Number $80302 \mathrm{MA}$ ) to a cobalt-60 source for a total exposure of $10^{8}$ RAD. To evaluate the quality assurance of the 1998 product, Reilly Industries Inc. also provided a sample of their latest 1999 Reillexf HPQ product (chloride form: Lot number 100698, batch number 1364.1).

\subsection{Experimental Procedures}

\subsubsection{Resin Preparations}

4.2.1.1. Standard Method for Resin Conversion from Chloride Form to Nitrate Form. The resins used in this study are commercially available as the chloride salts. Typically, approximately, $25 \mathrm{~mL}$ of resin (chloride form) were added to a $150-\mathrm{mL}$ beaker. The resin was slurried with about $50 \mathrm{~mL}$ of 1 molar sodium nitrate and loaded into a glass, $30-\mathrm{mL}$ ion exchange column. The chloride form resin was converted to the nitrate form resin by washing with ten bed volumes of 1 molar sodium nitrate. Excess sodium nitrate was removed by washing with ten bed volumes of water. The resin was collected by suction filtration and dried in a vacuum at approximately $70{ }^{\circ} \mathrm{C}$ for 12 hours to give a dry product. The dry product was stored in a plastic screw cap bottle until use.

\subsubsection{Pre-treatment of Resin Prior to Standard Chloride Form to Nitrate Form}

Conversion. In two of the resin tests, resin was pretreated with an organic solvent wash 
prior to the standard method for conversion to the nitrate form. Typically, approximately, $25 \mathrm{~mL}$ of resin were added to a $150-\mathrm{mL}$ beaker. A $50-\mathrm{mL}$ aliquot of organic solvent (methanol or acetone) was added and loaded into a glass $30-\mathrm{mL}$ ion exchange column. Pre-treatment was achieved by washing the loaded resin with ten bed volumes of the organic solvent. Subsequently, this pretreated resin was converted to nitrate form using the Standard Chloride Form to Nitrate Form Resin Conversion, as described above.

In two other resin tests, the resin was pretreated by digesting it in a hot aqueous solvent. Typically, approximately $25 \mathrm{~mL}$ of resin and a $50-\mathrm{mL}$ aliquot of aqueous solution $(12 \mathrm{M}$ $\mathrm{HNO}_{3}$ or distilled water) were added to a $150-\mathrm{mL}$ beaker. The 12 molar $\mathrm{HNO}_{3}$ mixture was boiled for three hours with a steady generation of $\mathrm{NO}_{\mathrm{x}}$ gas. The distilled water mixture was heated for three hours at $60{ }^{\circ} \mathrm{C}$; digestion at higher temperatures resulted in violent bumping. Subsequently, each pretreated resin was converted to nitrate form using the Standard Chloride Form to Nitrate Form Resin Conversion, as described above.

\subsubsection{RSST Testing}

4.2.2.1. Charging the test cell. First, 2.38 A 0.10 grams of the dry nitrate form resin were added to a tared 14-mL RSST test cell. Second, a nitric acid solution with a known specific gravity was added dropwise to the test cell until the required mass of nitric acid solution was added. Finally, a small Teflonf stir bar was added.

4.2.2.2. Loading the test cell into the calorimeter. A dual-bottom heater was wrapped around the test cell and secured with a heater belt. The test cell assembly was wrapped with an aluminum foil square. The wrapped test cell was placed into the insulation jacket, and sealed into the insulation sheath, with the four heater wires exiting through the grommet. The four heater wires were connected to the corresponding wires of the heater glands, and the insulation sheath assembly was lowered into the bottom of the Parr bomb. The Parr bomb was attached to the nitrogen line and was placed on a stir plate. Stirring

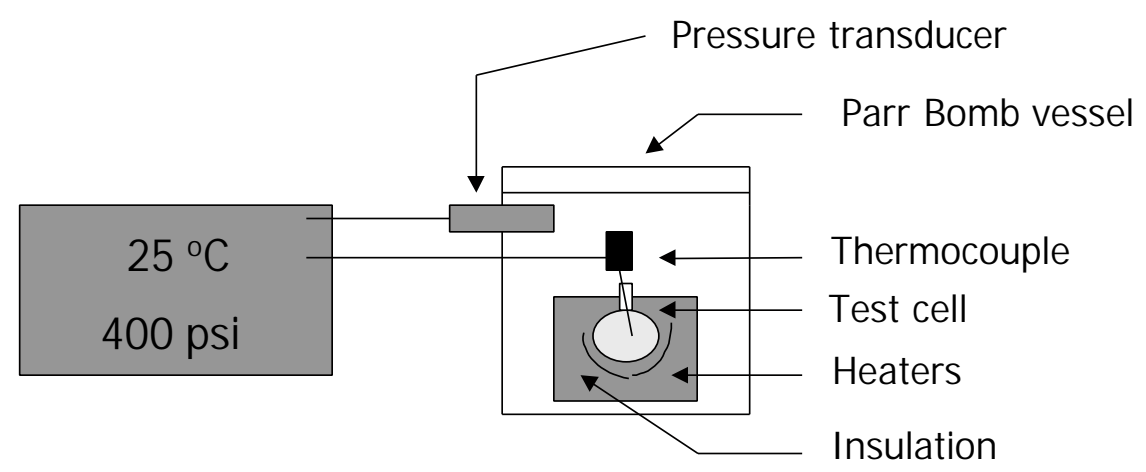

\section{Computer RSST}


was confirmed by visual inspection. A thermocouple was threaded through an extension tube and secured onto the top of the test cell. Temperature and pressure sensors were connected, the Parr bomb was sealed, and charged with nitrogen.

4.2.2.3. RSST operation. The test was initiated after the change in pressure with time, or pressure rate $(\Delta \mathrm{P} / \Delta \mathrm{t})$, was less than $0.20 \mathrm{psi} / \mathrm{min}$. The system was considered at thermal and pressure equilibrium. Unless otherwise noted, tests were run from room temperature to $300{ }^{\circ} \mathrm{C}$ with an imposed heating rate of $0.5^{\circ} \mathrm{C} / \mathrm{min}$ under $400 \mathrm{psig}$ (nitrogen gas). Preliminary RSST testing of resin/8 M nitric acid mixtures indicated that some vapor saturation ("boiling") occurred under 300 psig but could be avoided by running the tests at $400 \mathrm{psig}$. Vapor saturation increased the endothermic stripping of the water/nitric acid solvent and interfered with observation of exotherms. Generally, tests were run in "automatic shutdown mode" with shutdown criteria of 280 minutes, 650 psig, or $300{ }^{\circ} \mathrm{C}$.

\subsection{Experimental Data}

The RSST resin test conditions are described in Table 1. Each resin/nitric acid mixture was heated at a constant rate of $0.5^{\circ} \mathrm{C} / \mathrm{min}$ under $400 \mathrm{psig}$ of nitrogen gas in a sealed Parr bomb, unless otherwise noted. Ionacf A-641, Reillexf HPQ, and irradiated Reillexf HPQ were each tested in 8 and 12 molar nitric acid solutions in the presence and absence of $24 \mathrm{~g} / \mathrm{L}$ cerium (IV) ( 0.174 molar). Some tests were performed multiple times. Additional tests in Table 1 evaluated other characteristics of the runaway reaction including pressure dependency, the effect of heating at low-temperature for a long duration, and the effect of various pre-treatments prior to thermal stability testing using the RSST.

\section{Results}

\subsection{Reproducibility of the Method}

The reproducibility of the RSST method for the characterization of the runaway reaction between resin and nitric acid solutions was evaluated for Reillexf HPQ (nitrate form) in 8 molar $\mathrm{HNO}_{3}$. The runaway behavior is characterized by Figures $1-4$, which are annotated to identify the important features. In addition, the important parameters for the low-temperature and high-temperature exotherms are summarized in Tables 2 and 3, respectively.

The comparison of the time to maximum rates (TMR) between tests is only valid when heating mixtures of similar mass and heat capacity. The maximum temperature, selfheating rates, pressure, and pressure rates are valid for comparisons of solutions with different heat capacities. Furthermore, for comparing different resin reactions, the test conditions that should be duplicated include the mass of reactants, ratio of reactants, pressure of containment, imposed heating rate, and mixing rate. 
The reproducibility tests with Reillexf $\mathrm{HPQ}$ in $8 \mathrm{M} \mathrm{HNO}_{3}$ were run under the same conditions. The absolute errors in the TMR, maximum temperature, maximum selfheating rate $(\Delta \mathrm{T} / \Delta \mathrm{t})$, maximum pressure, and maximum pressure rates $(\Delta \mathrm{P} / \Delta \mathrm{t})$ in Tables 2 and 3 are reported as $K$ one standard deviation. These errors are a measure of the reproducibility of RSST testing of the Reillexf HPQ- $8 \mathrm{M} \mathrm{HNO}_{3}$ system, and do not include the propagation of errors within individual tests.

The reproducibility of RSST test with this resin/nitric acid system under an initial backpressure of nominally 410 psig is represented in Figures 1-4. In Figure 1, a small temperature excursion is observed at $127 \mathrm{~K} 6 \mathrm{~min}$ (3\% error), reaching a maximum temperature of $80 \mathrm{~K} 4{ }^{\circ} \mathrm{C} \mathrm{(4 \%} \mathrm{error).} \mathrm{A} \mathrm{large} \mathrm{temperature} \mathrm{excursion} \mathrm{is} \mathrm{observed} \mathrm{at}$ $240 \mathrm{~K} 8 \mathrm{~min}\left(4 \%\right.$ error), reaching a maximum temperature of $248 \mathrm{~K} 1{ }^{\circ} \mathrm{C}(0.4 \%$ error). Figure 2 shows that both the low and high-temperature excursions are associated with pressure excursions, evidence for the generation of gaseous reaction products. Figures 3 and 4 identify the intensity of the temperature and pressure excursions, perhaps the most informative plots for characterizing reactive systems. A low-temperature exotherm is observed with a self-heating rate $2 \mathrm{~K} 1{ }^{\circ} \mathrm{C} / \mathrm{min}$ (50\% error), and a small but observable pressure rate increase of $0.3 \mathrm{~K} 0.1 \mathrm{psi} / \mathrm{min}$ (33\% error). In addition, a high-temperature exotherm is observed with a self-heating rate of $105 \mathrm{~K} 40{ }^{\circ} \mathrm{C} / \mathrm{min}$ ( $30 \%$ error), a pressure rate increase of $274 \mathrm{~K} 21 \mathrm{psi} / \mathrm{min}$ (7\% error), and a maximum pressure of $570 \mathrm{~K} 6 \mathrm{psig}$ ( $1 \%$ error). The experimental determination of the TMR, maximum temperature and maximum pressure for this reaction in the RSST were determined with relatively high precision. However, the maximum self-heating rates and maximum pressure rates were determined with much less precision and must be viewed more qualitatively. This loss in precision can be attributed to heat losses due to differences in sample stirring and heater configuration around the test cell. In addition, even under $400 \mathrm{psi}$ backpressure, the resin/nitric acid system is tempered (solvent is vaporizing) in the RSST. Differences in the tempering rate result in differences in the composition of the cell contents at the time of the exotherms, and contribute to variations in experimental self-heating and pressure rates. Although the experimental values are less precise for the low-temperature exotherm, the RSST was sufficiently sensitive to identify this exotherm with measured self-heating rates as low as $1{ }^{\circ} \mathrm{C} / \mathrm{min}$, only slightly higher than the imposed self-heating rate of $0.5^{\circ} \mathrm{C} / \mathrm{min}$.

\subsection{Pressure Dependency of the Resin/Nitric Acid Reactions.}

One of the limitations of this screening method is evaporative loss of solvent from the test cell during the RSST test. Running the test under a large backpressure of nitrogen minimizes evaporation. Table 4 summarizes the pressure-temperature-time characteristics for the Reillexf HPQ-nitric acid reaction as a function of pressure. Figure 5 depicts the effect of backpressure on the time to maximum rate. At 0 psig, the flat portion of the plot is due to saturation of the vapor phase, limiting the temperature rise. No exotherm was observed after 280 minutes, although essentially all solvent had been stripped. With larger backpressures of 200 and $400 \mathrm{psig}$, the temperature rise was not limited by vapor saturation until 215 and $250{ }^{\circ} \mathrm{C}$, respectively. 
Table 1. Resin Tests Performed in the RSST Calorimeter.

\begin{tabular}{|c|c|c|c|c|c|c|c|}
\hline RSST & & & & Mass & Mass & Sp. Gr. & Plotted \\
\hline Test & & {$\left[\mathrm{HNO}_{3}\right]$} & {$[\mathrm{Ce}]$} & Resin & $\mathrm{HNO}_{3}(\mathrm{aq})$ & $\mathrm{HNO}_{3}(\mathrm{aq})$ & In \\
\hline Number & Reactant & $\mathbf{M}$ & $\mathrm{g} / \mathrm{L}$ & $\mathbf{g}$ & $\mathbf{g}$ & $\mathbf{g} / \mathbf{m L}$ & Figure No. \\
\hline \#113 & $\begin{array}{ll}\text { Ionacf } & \text { A-641 }\end{array}$ & 8 & 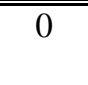 & 2.86 & 7.61 & 1.24 & $\begin{array}{c}7-10,15-18, \\
21-23\end{array}$ \\
\hline$\# 111$ & Ionacf $\mathrm{A}-641$ & 12 & 0 & 2.86 & 12.67 & 1.33 & $11-14,19,20$ \\
\hline$\# 133$ & Ionacf A-641 & 8 & 24 & 2.86 & 10.03 & 1.28 & $15-18,34,35$ \\
\hline$\# 131$ & Ionacf $\mathrm{A}-641$ & 12 & 24 & 2.87 & 12.67 & 1.36 & 19,20 \\
\hline$\# 115$ & Reillexf HPQ & 8 & 0 & 2.86 & 7.38 & 1.24 & $\begin{array}{l}1,-10,36 \\
38-44,45\end{array}$ \\
\hline$\# 135$ & Reillexf HPQ & 8 & 0 & 2.86 & 7.38 & 1.24 & $1-4$ \\
\hline$\# 143$ & Reillexf HPQ & 8 & 0 & 2.86 & 7.38 & 1.24 & $1-4$ \\
\hline$\# 137$ & Reillexf HPQ & 8 & 0 & 2.86 & 7.37 & 1.24 & $1-4$ \\
\hline$\# 191$ & $\begin{array}{l}\text { Reillexf HPQ, } \\
\text { (air-dried) }\end{array}$ & 8 & 0 & 2.87 & 7.38 & 1.24 & $1-4$ \\
\hline$\# 117$ & Reillexf HPQ & 12 & 0 & 2.86 & 9.73 & 1.33 & $11-14,24-26$ \\
\hline$\# 123$ & Reillexf HPQ & 8 & 24 & 2.86 & 7.38 & 1.28 & $21-23,34,35$ \\
\hline$\# 125$ & Reillexf HPQ & 12 & 24 & 2.86 & 9.74 & 1.36 & $24-26$ \\
\hline$\# 119$ & Irrad. Reillexf HPQ & 8 & 0 & 2.86 & 7.35 & 1.28 & $7-10,27-32$ \\
\hline$\# 121$ & Irrad. Reillexf HPQ & 12 & 0 & 2.86 & 7.36 & 1.33 & $11-14,30-32$ \\
\hline$\# 127$ & Irrad. Reillexf HPQ & 8 & 24 & 2.87 & 7.36 & 1.28 & $27-29,34,35$ \\
\hline$\# 129$ & Irrad. Reillexf HPQ & 12 & 24 & 2.86 & 9.76 & 1.36 & 31,32 \\
\hline$\# 161$ & $\begin{array}{c}\text { Reillexf HPQ, } \\
200 \text { psi }\end{array}$ & 8 & 0 & 2.88 & 7.41 & 1.24 & 5,6 \\
\hline$\# 163$ & $\begin{array}{c}\text { Reillexf HPQ, } \\
0 \text { psig }\end{array}$ & 8 & 0 & 2.88 & 7.35 & 1.24 & 5,6 \\
\hline$\# 141$ & $\begin{array}{c}\text { Reillexf HPQ, } \\
0.25^{\circ} \mathrm{C} / \mathrm{min}, \\
\text { hold } 100^{\circ} \mathrm{C} \text { for } 10 \mathrm{~h}\end{array}$ & 8 & 0 & 2.86 & 7.37 & 1.24 & 33 \\
\hline$\# 145$ & $\begin{array}{c}\text { Ionacf A-641, } \\
0.25^{\circ} \mathrm{C} / \mathrm{min}, \\
\text { hold } 100^{\circ} \mathrm{C} \text { for } 10 \mathrm{~h}\end{array}$ & 8 & 0 & 2.74 & 6.32 & 1.24 & 33 \\
\hline$\# 147$ & $\begin{array}{c}\text { Reillexf } \mathrm{HPQ} \\
\text { Boiled in } 12 \mathrm{M} \mathrm{HNO}_{3}\end{array}$ & 8 & 0 & 2.87 & 10.80 & 1.24 & 38 \\
\hline$\# 165$ & $\begin{array}{l}\text { Reillexf HPQ, } \\
\text { Boiled in water }\end{array}$ & 8 & 0 & 2.86 & 7.37 & 1.24 & 37 \\
\hline$\# 167$ & $\begin{array}{l}\text { Reillexf HPQ, } \\
\text { MeOH washed }\end{array}$ & 8 & 0 & 2.86 & 7.38 & 1.24 & 37 \\
\hline
\end{tabular}


Table 1 -CONTINUED. Resin Tests Performed in the RSST Calorimeter.

\begin{tabular}{|c|c|c|c|c|c|c|c|}
\hline RSST & & & & Mass & Mass & Sp. Gr. & Plotted \\
\hline Test & & {$\left[\mathrm{HNO}_{3}\right]$} & [Ce] & Resin & $\mathrm{HNO}_{3}(\mathrm{aq})$ & $\mathrm{HNO}_{3}(\mathrm{aq})$ & In \\
\hline Number & Reactant & M & g/L & $\mathbf{g}$ & $\mathbf{g}$ & $\mathbf{g} / \mathbf{m L}$ & Figure No. \\
\hline \#169 & $\begin{array}{l}\text { Reillexf HPQ, } \\
\text { Acetone washed }\end{array}$ & 8 & 0 & 2.87 & 7.38 & 1.24 & 37 \\
\hline \#171 & $\begin{array}{l}\text { Reillexf HPQ, } \\
+200 \mathrm{uL} \mathrm{MeOH}\end{array}$ & 8 & 0 & 2.87 & 7.36 & 1.24 & 40 \\
\hline$\# 173$ & $\begin{array}{l}\text { Reillexf HPQ, } \\
+100 \mathrm{uL} \mathrm{MeOH}\end{array}$ & 8 & 0 & 2.87 & 7.36 & 1.24 & 40 \\
\hline$\# 151$ & $\begin{array}{l}\text { Reillexf HPQ, } \\
+50 \mathrm{uL} \mathrm{MeOH}\end{array}$ & 8 & 0 & 2.87 & 12.02 & 1.24 & 40 \\
\hline$\# 177$ & $\begin{array}{l}\text { Reillexf HPQ, } \\
+7.39 \text { g pump oil }\end{array}$ & 0 & 0 & 3.01 & 0 & $\mathrm{n} / \mathrm{a}$ & 36 \\
\hline$\# 185$ & $\begin{array}{c}\text { Reillexf HPQ, } \\
+0.1 \mathrm{~g} \text { methylbenzoate }\end{array}$ & 8 & 0 & 2.86 & 7.35 & 1.24 & 41 \\
\hline \#198 & $\begin{array}{l}\text { Reillexf HPQ, } \\
\text { (heat-treated, dry) }\end{array}$ & 8 & 0 & 2.87 & 10.14 & 1.24 & 39 \\
\hline$\# 190$ & $\begin{array}{c}\text { Reillexf HPQ, } \\
\text { (air-dried, 1999 Lot No.) }\end{array}$ & 8 & 0 & 2.87 & 9.35 & 1.24 & \\
\hline$\# 182$ & $\begin{array}{c}\text { No resin, } \\
+2.93 \mathrm{~g} \text { styrene }\end{array}$ & 8 & 0 & 0 & 11.00 & 1.24 & 42 \\
\hline \#178 & $\begin{array}{rl} & \text { No resin, } \\
+1.00 & \mathrm{~g} \text { diethylbenzene }\end{array}$ & 8 & 0 & 0 & 11.02 & 1.24 & 43 \\
\hline$\# 172$ & $\begin{array}{rl} & \text { No resin, } \\
+1.45 & \mathrm{~g} \text { diethylbenzene }\end{array}$ & 8 & 0 & 0 & 10.04 & 1.24 & 43 \\
\hline$\# 180$ & $\begin{array}{rl} & \text { No resin, } \\
+2.92 & \mathrm{~g} \text { diethylbenzene }\end{array}$ & 8 & 0 & 0 & 10.92 & 1.24 & 43 \\
\hline$\# 174$ & $\begin{aligned} & \text { No resin, } \\
&+3.08 \mathrm{~g} \text { diethylbenzene }\end{aligned}$ & 8 & 0 & 0 & 10.03 & 1.24 & 43 \\
\hline$\# 160$ & $\begin{array}{l}\text { Reillexf HPQ, } \\
\text { (after } 30 \mathrm{~min}, 85^{\circ} \mathrm{C} \\
\text { in } 8 \mathrm{M} \mathrm{HNO}_{3} \text { ) }\end{array}$ & 8 & 0 & 2.88 & 8.58 & 1.24 & 44 \\
\hline$\# 150$ & $\begin{array}{c}\text { Reillexf HPQ, } \\
\text { (after } 50 \text { grams at } 45 \text { min, } \\
85^{\circ} \mathrm{C} 8 \mathrm{M} \mathrm{HNO}_{3} \text { ) }\end{array}$ & 8 & 0 & 2.88 & 8.08 & 1.24 & 44 \\
\hline$\# 138$ & $\begin{array}{c}\text { Reillexf HPQ, } \\
\text { (LTE, } \Delta \mathrm{P} \text { determination) }\end{array}$ & 8 & 0 & 2.87 & 7.37 & 1.24 & \\
\hline
\end{tabular}


Table 2. Low-Temperature Exotherm Characterization of the Reaction of Reillexf HPQ and $8 \mathrm{M} \mathrm{HNO}_{3}$ [Imposed Heating Rate $=0.5^{\circ} \mathrm{C} / \mathrm{min}, 410 \mathrm{psig}$ ].

\begin{tabular}{|c|c|c|c|c|c|}
\hline RSST Test & Max. T & Max. P & Time to Max. & Max. Rate: & Max. Rate: \\
\hline Number & $\left.\mathbf{(}^{\mathbf{0}} \mathbf{C}\right)$ & $\mathbf{( p s i )}$ & Rate $(\mathbf{m i n})$ & $\Delta \mathbf{T} / \Delta \mathbf{t}\left({ }^{\mathbf{0}} \mathbf{C} / \mathbf{m i n}\right)$ & $\Delta \mathbf{P} / \Delta \mathbf{t}(\mathbf{p s i} / \mathbf{m i n})$ \\
\hline$\# 115$ & 78 & 421 & 120 & 3.7 & 0.47 \\
\hline$\# 135$ & 84 & 423 & 130 & 0.7 & 0.17 \\
\hline$\# 137$ & 81 & 417 & 123 & 1.0 & 0.27 \\
\hline$\# 143$ & 84 & 416 & 126 & 1.1 & 0.22 \\
\hline$\# 191$ & 76 & 437 & 136 & 1.5 & 0.25 \\
\hline \hline Average & 80 & 423 & 127 & 2 & 0.3 \\
\hline Std. Dev. & 4 & 8 & 6 & 1 & 0.1 \\
\hline
\end{tabular}

Table 3. High-Temperature Exotherm Characterization of the Reaction of Reillexf $\mathrm{HPQ}$ and $8 \mathrm{M} \mathrm{HNO}_{3}$ [Imposed Heating Rate $=0.5^{\circ} \mathrm{C} / \mathrm{min}, 410 \mathrm{psig}$ ].

\begin{tabular}{|c|c|c|c|c|c|}
\hline RSST Test & Max. T & Max. P & Time to Max. & Max. Rate: & Max. Rate: \\
\hline Number & $\left.\mathbf{(}^{\mathbf{0}} \mathbf{C}\right)$ & $(\mathbf{p s i g})$ & Rate $(\mathbf{m i n})$ & $\Delta \mathbf{T} / \Delta \mathbf{t}\left({ }^{\mathbf{0}} \mathbf{C} / \mathbf{m i n}\right)$ & $\Delta \mathbf{P} / \Delta \mathbf{t}(\mathbf{p s i} / \mathbf{m i n})$ \\
\hline$\# 115$ & 250 & 569 & 233 & 166 & 257 \\
\hline$\# 135$ & 249 & 580 & 236 & 86 & 291 \\
\hline$\# 137$ & 247 & 568 & 248 & 105 & 250 \\
\hline$\# 143$ & 248 & 563 & 251 & 110 & 272 \\
\hline$\# 191$ & 248 & 572 & 234 & 58 & 298 \\
\hline \hline Average & 248 & 570 & 240 & 105 & 274 \\
\hline Std. Dev. & 1 & 6 & 8 & 40 & 21 \\
\hline
\end{tabular}

Table 4. Effect of Pressure on the Reillexf HPQ and Nitric Acid Reaction

\begin{tabular}{|c|c|c|c|c|c|c|}
\hline $\begin{array}{c}\text { RSST } \\
\text { Test } \\
\text { Number }\end{array}$ & $\begin{array}{c}\text { All tests } \\
\text { Were done } \\
\text { in } 8 \mathrm{M} \mathrm{HNO}_{3}\end{array}$ & $\begin{array}{c}\text { Time to } \\
\text { Max. } \\
\text { Rate } \\
(\Delta \mathrm{T} / \Delta \mathrm{t}) \\
(\mathrm{min})\end{array}$ & $\begin{array}{c}\text { Max. T } \\
\left({ }^{\circ} \mathrm{C}\right)\end{array}$ & $\begin{array}{c}\text { Max } \\
\text { Rate: } \\
\Delta \mathrm{T} / \Delta \mathrm{t}: \\
\left({ }^{\circ} \mathrm{C} / \mathrm{min}\right)\end{array}$ & $\begin{array}{c}\text { Max. P } \\
\text { (psi) }\end{array}$ & $\begin{array}{c}\text { Max } \\
\text { Rate: } \\
\Delta \mathbf{P} / \Delta t \\
\text { (psi/min) }\end{array}$ \\
\hline \multirow[t]{2}{*}{$\# 159$} & \multirow{2}{*}{$\begin{array}{c}\text { Reillexf HPQ, } \\
400 \text { psig }\end{array}$} & 125 & 87 & 3 & 425 & 0.4 \\
\hline & & 222 & 250 & 110 & 580 & 120 \\
\hline \multirow[t]{2}{*}{$\# 161$} & \multirow{2}{*}{$\begin{array}{c}\text { Reillexf HPQ, } \\
200 \text { psig }\end{array}$} & 122 & 82 & 0.2 & 212 & 0.4 \\
\hline & & 187 & 217 & 114 & 298 & 40 \\
\hline \multirow[t]{2}{*}{$\# 163$} & \multirow{2}{*}{$\begin{array}{c}\text { Reillexf HPQ, } \\
0 \text { psig }\end{array}$} & 103 & 87 & 0.2 & 0 & 0 \\
\hline & & $\begin{array}{c}\text { Not } \\
\text { observed* }\end{array}$ & --- & --- & --- & --- \\
\hline
\end{tabular}

*At 0 psig, no high-temperature exotherm was observed, the solvent had evaporated, and cell contents were dry. 
The differences in the RSST tests run under 200 and 400 psig are attributed differences in the rates of solvent loss. Solvent loss (as water evaporation) results in an increase nitric acid concentration of the reactant solution. Higher backpressure minimizes solvent stripping so that less solvent is lost under 400 psig than 200 psig as a function of time. This change in the composition of reactants, which creates a more reactive system, is an artifact of the RSST. Figure 6 shows the intensity of the exothermic reaction (selfheating rate) as a function of temperature. Note that the low-temperature exotherm is observed in all cases, and is not affected by the backpressure. However, for the hightemperature runaway reaction, as the backpressure is increased, the maximum selfheating rate occurs at a higher temperature.

Due to the observed effects of solvent stripping on the reactivity of the resin mixtures, routine RSST tests were run under nominally 410 psig to suppress solvent loss, and to maintain the original reactant composition.

\subsection{Comparison of Nitric Acid-Resins Reaction Profiles}

The RSST reaction profiles of Ionacf A-641, Reillexf HPQ, and irradiated Reillexf HPQ resins were compared in nitric acid solution in the presence and absence of cerium (IV). Tables 5-7 summarize the pressure-temperature-time characteristics.

\subsubsection{Resins in $8 \mathrm{M}$ and $12 \mathrm{M} \mathrm{HNO}_{3}$.}

The reaction profiles are shown for 8 and 12 molar nitric acid mixtures in Figures 7-10 and Figures 11-14, respectively. Thermal effects were observed in two general regions: the low-temperature Region I $\left(<100{ }^{\circ} \mathrm{C}\right)$, high-temperature Region II $\left(>100{ }^{\circ} \mathrm{C}\right)$. The exotherms in Region I can be attributed to a small amount of an easily-oxidized material, whereas the exotherms in Region II may be attributed to general oxidative degradation of aromatic-alkyl cross-linking groups of the resin. ${ }^{6}$

The time-temperature profile in Figure 7 shows the high-temperature excursion for all three resins, but only shows a low-temperature exotherm for unirradiated Reillexf HPQ. The absence of the low-temperature exotherm for irradiated Reillexf HPQ suggests that the irradiation treatment (100 MRad) eliminated the low temperature exotherm. In other words, the low-temperature exothermic reaction occurred as a result of irradiation. This implies that gas and heat will be evolved due to an irradiation-initiated exotherm. The amounts of gas and heat evolved during the irradiation were not determined.

Figure 8 shows the pressure-time profiles, with the low-temperature pressure excursion barely discernable. Figures 9 and 10 show the self-heating rate-temperature and pressure rate-temperature profiles. Below $100{ }^{\circ} \mathrm{C}$, only Reillexf HPQ showed self-heating and pressure rate increases. Just above $100{ }^{\circ} \mathrm{C}$, the self-heating rates and pressure rates are erratic as the runaway reactions initiate, followed by steady exponential increases as the runaway reactions self-accelerate. The maximum self-heating rates are comparable for all three resins, although Ionacf A-641 has an additional local maximum at $140{ }^{\circ} \mathrm{C}$. 
Table 5. Characterization of the Reaction of Ionacf A-641 and Nitric Acid Solutions [Imposed Heating Rate $=0.5^{\circ} \mathrm{C} / \mathrm{min}, 400 \mathrm{psi}$ ].

\begin{tabular}{|c|c|c|c|c|c|c|}
\hline $\begin{array}{c}\text { RSST } \\
\text { Test } \\
\text { Number }\end{array}$ & Recipe & $\begin{array}{c}\text { Time to } \\
\Delta \mathrm{P} / \Delta \mathrm{t} \\
\text { Max. Rate } \\
\text { (min) }\end{array}$ & $\begin{array}{c}\text { Max. T } \\
\left({ }^{\circ} \mathrm{C}\right)\end{array}$ & $\begin{array}{c}\text { Max } \\
\text { Rate: } \\
\Delta \mathrm{T} / \Delta \mathrm{t}: \\
\left({ }^{\circ} \mathrm{C} / \mathrm{min}\right)\end{array}$ & $\begin{array}{c}\text { Max. P } \\
\text { (psi) }\end{array}$ & $\begin{array}{c}\text { Max } \\
\text { Rate: } \\
\Delta \mathrm{P} / \Delta \mathrm{t} \\
\text { (psi/min) }\end{array}$ \\
\hline$\# 113$ & $8 \mathrm{M} \mathrm{HNO}_{3}$ & 243 & 242 & 110 & 515 & 113 \\
\hline$\# 111$ & $12 \mathrm{M} \mathrm{HNO}_{3}$ & 227 & 225 & 104 & 515 & 30 \\
\hline$\# 133$ & $\begin{array}{c}8 \mathrm{M} \mathrm{HNO}_{3}, \\
24 \mathrm{~g} / \mathrm{L} \mathrm{Ce}\end{array}$ & 243 & 236 & 132 & 522 & 120 \\
\hline \#131 & $\begin{array}{c}12 \mathrm{M} \mathrm{HNO}_{3}, \\
24 \mathrm{~g} / \mathrm{L} \mathrm{Ce}\end{array}$ & 252 & 235 & 53 & 530 & 100 \\
\hline
\end{tabular}

Table 6. Characterization of the Reaction of Reillexf HPQ and Nitric Acid Solutions [Imposed Heating Rate $=0.5{ }^{\circ} \mathrm{C} / \mathrm{min}, 400 \mathrm{psi}$ ].

\begin{tabular}{|c|c|c|c|c|c|c|}
\hline $\begin{array}{c}\text { RSST } \\
\text { Test } \\
\text { Number }\end{array}$ & Recipe & $\begin{array}{c}\text { Time to } \\
\text { Max. Rate } \\
\Delta \mathbf{P} / \Delta \mathbf{t} \\
(\mathbf{m i n})\end{array}$ & $\begin{array}{c}\text { Local } \\
\text { Or } \\
\text { Max. T } \\
\left({ }^{\circ} \mathbf{C}\right)\end{array}$ & $\begin{array}{c}\text { Max } \\
\text { Rate: } \\
\Delta \mathrm{T} / \Delta \mathrm{t}: \\
\left({ }^{\mathrm{o}} \mathrm{C} / \mathrm{min}\right)\end{array}$ & $\begin{array}{c}\text { Local } \\
\text { Or } \\
\text { Max. P } \\
\text { (psig) }\end{array}$ & $\begin{array}{c}\text { Max. } \\
\text { Rate: } \\
\Delta \mathbf{P} / \Delta t \\
\text { (psi/min) }\end{array}$ \\
\hline \multirow{2}{*}{$\begin{array}{l}\text { Avg. Table } 2 \\
\text { Avg. Table } 3\end{array}$} & \multirow[t]{2}{*}{$8 \mathrm{M} \mathrm{HNO}_{3}$} & 125 & 82 & 2 & 419 & 0.3 \\
\hline & & 242 & 248 & 117 & 570 & 268 \\
\hline \multirow[t]{2}{*}{$\# 117$} & \multirow[t]{2}{*}{$12 \mathrm{M} \mathrm{HNO}_{3}$} & 95 & 75 & 1 & 420 & 0.2 \\
\hline & & 163 & 250 & 104 & 590 & 134 \\
\hline \multirow[t]{2}{*}{$\# 123$} & \multirow{2}{*}{$\begin{array}{c}8 \mathrm{M} \mathrm{HNO}_{3} \\
24 \mathrm{~g} / \mathrm{L} \mathrm{Ce}\end{array}$} & 105 & 72 & 2 & 418 & 0.2 \\
\hline & & 172 & 250 & 103 & 573 & 110 \\
\hline \multirow[t]{2}{*}{ \#125 } & \multirow{2}{*}{$\begin{array}{c}12 \mathrm{M} \mathrm{HNO}_{3}, \\
24 \mathrm{~g} / \mathrm{L} \mathrm{Ce}^{2}\end{array}$} & 105 & 71 & 2 & 418 & 0.2 \\
\hline & & 217 & 247 & 105 & 568 & 131 \\
\hline
\end{tabular}


Table 7. Characterization of the Reaction of Irradiated Reillexf HPQ and Nitric Acid Solutions [Imposed Heating Rate $=0.5^{\circ} \mathrm{C} / \mathrm{min}, 400 \mathrm{psi}$ ].

\begin{tabular}{|c|c|c|c|c|c|c|}
\hline $\begin{array}{c}\text { RSST } \\
\text { Test } \\
\text { Number }\end{array}$ & Recipe & $\begin{array}{c}\text { Time to } \\
\text { Max. Rate } \\
\Delta \mathbf{P} / \Delta t \\
\text { (min) }\end{array}$ & $\begin{array}{c}\text { Local } \\
\text { Or } \\
\text { Max. T } \\
\left({ }^{\circ} \mathrm{C}\right)\end{array}$ & $\begin{array}{c}\text { Max } \\
\text { Rate: } \\
\Delta \mathrm{T} / \Delta \mathrm{t}: \\
\left({ }^{0} \mathrm{C} / \mathrm{min}\right)\end{array}$ & $\begin{array}{c}\text { Local } \\
\text { or } \\
\text { Max. P } \\
\text { (psig) }\end{array}$ & $\begin{array}{c}\text { Max. } \\
\text { Rate: } \\
\Delta \mathbf{P} / \Delta t \\
\text { (psi/min) }\end{array}$ \\
\hline \multirow[t]{2}{*}{ \#119 } & \multirow[t]{2}{*}{$8 \mathrm{M} \mathrm{HNO}_{3}$} & \multicolumn{5}{|c|}{ Low-temperature exotherm was not observed } \\
\hline & & 256 & 246 & 105 & 548 & 131 \\
\hline \multirow[t]{2}{*}{$\# 121$} & $12 \mathrm{M} \mathrm{HNO}_{3}$ & \multicolumn{5}{|c|}{ Low-temperature exotherm was not observed } \\
\hline & & 179 & 247 & 84 & 565 & 124 \\
\hline \multirow[t]{2}{*}{ \#127 } & $8 \mathrm{M} \mathrm{HNO}_{3}$, & \multicolumn{5}{|c|}{ Low-temperature exotherm was not observed } \\
\hline & & 268 & 245 & 120 & 545 & 110 \\
\hline \multirow[t]{2}{*}{$\# 129$} & $12 \mathrm{M} \mathrm{HNO}_{3}$, & \multicolumn{5}{|c|}{ Low-temperature exotherm was not observed } \\
\hline & $24 \mathrm{~g} / \mathrm{L} \mathrm{Ce}$ & 273 & 240 & 102 & 545 & 103 \\
\hline
\end{tabular}

Above $100{ }^{\circ} \mathrm{C}$, these results indicate that Reillexf HPQ is comparable to Ionacf A-641 with respect to chemical reactivity. The irradiated form has a more erratic self-heating rate than the unirradiated form. However, the runaway behaviors are comparable in intensity and the temperature at which they occur. Below $100{ }^{\circ} \mathrm{C}$, a low-intensity exotherm is observed only for Reillexf HPQ. A small amount of easily-oxidized material may be reacting at approximately $80{ }^{\circ} \mathrm{C}$. Additional testing of the lowtemperature exothermic reaction was required to identify its origin and to evaluate its significance with respect to pressure generation.

The easily-oxidized material was may be a residual additive used in processing (methanol, acetone, or methyl benzoate), unreacted cross-linking agent (styrene), a phase change or swelling, or an easily-oxidized resin component. These possibilities are discussed in SECTION 5.4.

The low temperature exotherm was not unique to this batch of Reillexf HPQ resin, but was also observed in RSST tests with Reillexf HPQ from a 1999 production run, and with polyvinylpyridine (25\% cross-linked) sold by Aldrich Chemical Company but also produced by Reilly Industries.

\subsubsection{Resins in Cerium(IV)-Nitric Acid Solutions.}

5.3.2.1. The Effect of Cerium(IV) on Each Resin. The effect of 0.174 molar cerium (IV) on each resin/nitric acid reaction was evaluated for each resin. The RSST profiles are presented in Figures 15-32. The cerium-laden mixture might increase the reactivity of the resins by increasing the local concentration of nitrate or by catalytic pathways.

For Ionacf A-641 resin, Figure 15 shows that cerium had no effect on the time to maximum rates. Figures 16 and 17 show self-heating and pressure generation initiating 
after $100{ }^{\circ} \mathrm{C}$ for both mixtures. From 100 to $160{ }^{\circ} \mathrm{C}$, the cerium-resin mixture has lower self-heating and pressure rates. At higher temperatures, these self-heating and pressure rates are similar. The same comparisons in 12 molar nitric acid mixtures are given in Figures 18-20. The cerium test had a longer TMR (Figure 18). However, this finding may not be significant. The time difference may be attributed to differences in heat capacities of the mixtures that result in different imposed heating rates. Figures 19 and 20 show comparable self-heating and pressure rates, although above $150{ }^{\circ} \mathrm{C}$, these rates are higher with the cerium-laden mixture.

For Reillexf HPQ resin, Figure 21 shows that the presence of cerium(IV) in 8 molar nitric acid results in a difference in the TMR. In this case, the cerium-laden mixture reached maximum rate in a shorter time than the cerium-free mixture, but this difference may again be attributed to differences in heat capacities. An important finding, which is shown in Figures 22 and 23, is that the presence of cerium(IV) in 8 molar nitric acid results in a continuous increase in pressure and self-heating rates from the lowtemperature exotherm to the high-temperature exotherm. In contrast, in the absence of cerium(IV), the self-heating and pressure rates return to baseline values after the lowtemperature exotherm, and initiate runaway behavior at $105^{\circ} \mathrm{C}$. In 12 molar nitric acid solution, the effect of cerium(IV) is less noticeable. Figures 24 show differences in the TMR, however the reactivity characterization in Figures 25 and 26 show comparable behavior; for both tests a continuous increase in pressure and self-heating rates from the low-temperature exotherm to the high-temperature exotherm is observed.

For irradiated Reillexf HPQ resin, for which no low-temperature exothermic reaction was observed (Section 5.4.1), the RSST tests in 8 and 12 molar nitric acid in the presence and absence of cerium(IV) are almost identical (Figures 27-32). The pressure and selfheating rates do not increase until a temperature of $100{ }^{\circ} \mathrm{C}$ is exceeded.

This latter result for irradiated Reillexf HPQ highlights the influence of the lowtemperature exothermic reaction on the reactivity of the unirradiated resin. For unirradiated Reillexf HPQ resin in 8 molar nitric acid (with cerium) or in 12 molar nitric acid (with or without cerium), the low and high-temperature exothermic reactions occur simultaneously between about 90 and $100{ }^{\circ} \mathrm{C}$. This "peak overlap" observed in the RSST reaction profiles suggests that the low-temperature exothermic reaction may have the capacity to supply energy to initiate the high-temperature reaction. To address this issue, the reactivities of Reillexf HPQ and Ionacf A-641 in 8 molar nitric acid solutions were compared (Figure 33) at $101{ }^{\circ} \mathrm{C}( \pm 2)$ over 8 hours in the RSST. For Ionacf A-641, no reaction was observed even after the sample went dry. For Reillexf HPQ, the lowtemperature reaction was observed (onset at $73{ }^{\circ} \mathrm{C}$ ) but the high-temperature reaction was not observed until 8.7 hours (held at temperature). The observance of the hightemperature exothermic reaction is an artifact due to the solvent stripping that occurs during the RSST test. At 8.7 hours, most of the nitric acid solvent had been stripped from the test cell, resulting in more concentrated nitric acid solution, and thus, a more reactive system. This test showed that the low temperature exothermic reaction of Reillexf HPQ did not initiate the high-temperature exothermic reaction, and that the high-temperature reaction only occurred after cell contents went dry. 
In summary, for Ionacf A-641 and for irradiated Reillexf HPQ, no increase in reactivity was observed in the presence of cerium(IV) in 8 and 12 molar nitric acid. For Reillexf HPQ, both cerium(IV)-laden and 12 molar nitric acid solutions produced low intensity pressure rates and self-heating rates that were continuous between the low- and high-temperature exothermic reactions. Finally, in 8 molar nitric acid, the energy released from the low-temperature exothermic reaction was not sufficient to activate the high-temperature exothermic reaction.

5.3.2.2. Comparison of the Effect of Cerium(IV) for Each Resin. The self-heating rate profiles of the different resins in the presence of cerium(IV) in 8 and 12 molar nitric acid are compared in Figures 34 and 35, respectively. An interesting feature is scatter in the Reillexf HPQ plots (in which the low-temperature exotherm is observed) that is noticeably absent in the other tests (in which the low-temperature exotherm is absent). For all three resins in cerium(IV)- nitric acid solution, the self-heating rates show two distinct high-temperature exotherms at 150 and $215{ }^{\circ} \mathrm{C}$.

\subsection{Low-temperature Exothermic Reaction of Reillexf HPQ}

The origin of the low-temperature exotherm of Reillexf HPQ was investigated. Clearly, a reactive material is generating small amounts of heat and gas. Some of the possible reactive materials that were considered are a residual additive used in processing (methanol, acetone, or methyl benzoate), unreacted cross-linking agent (styrene), a phase change or swelling, and an easily-oxidized resin component.

\subsubsection{Evaluation of Resin Alone.}

First, the possibility the low-temperature exotherm was due to the resin alone was investigated. Reillexf HPQ (nitrate form) was heated using typical vacuum pump oil as the solvent. No nitric acid was present. Figure 36 shows that no low-temperature exothermic reaction in the inert reaction medium, pump oil. This result is evidence that the low-temperature exothermic reaction for Reillexf HPQ involves nitric acid, and eliminates the possibilities of phase change, swelling, and heat induced reaction of crosslinking agent.

\subsubsection{Pre-Treatments to Remove Residual Chemicals.}

Next, the presence of residual chemicals from the resin production was evaluated. First, experiments were performed to determine if a reactive material could be removed from the resin by washing it with water (hot), methanol, or acetone. Figure 37 shows that the low-temperature exotherm is still present after all three washes. A subsequent treatment, which involved boiling Reillexf HPQ in 12 molar nitric acid, did remove the exotherm (Figure 38), however, visual inspection showed that this latter treatment transformed the spherical resin beads into a large distribution of small fragments. Judging from the change in particle size, it is likely that this treated resin will result in undesirably large pressure changes ("pressure drop") for flow across a column bed. 
Also, a dry-resin heat treatment was also used to try to eliminate the low-temperature exotherm. The resin turned from white to brown upon heating at $105{ }^{\circ} \mathrm{C}$ for 16 hours. However, the low-temperature exotherm in 8 molar nitric acid was still observed as shown in Figure 39.

\subsubsection{Nitric Acid Reactions of Methanol and Methyl Benzoate.}

Another possibility is that residual materials are entrained within the Reillexf HPQ resin beads. Reilly Industries Inc. has indicated that methanol and an aromatic methyl ester were during the production of Reillexf HPQ. Therefore, the reaction profiles of methanol and methyl benzoate (an aromatic methyl ester) in 8 molar nitric acid in the RSST were determined and compared to the low-temperature exotherm. Figure 40 shows a series of spikes with various quantities of methanol in 8 molar nitric acid (with no resin present). The methanol-nitric acid exothermic reaction has peak self-heating rates between 105 and $117^{\circ} \mathrm{C}$. Methyl benzoate was spiked into a Reillexf HPQ-8 molar nitric acid mixture to see if the intensity of the low-temperature exotherm increased (Figure 41). A peak self-heating rate at about $104{ }^{\circ} \mathrm{C}$ is consistent with the nitric acid reaction of methanol, generated in situ by the acid catalyzed hydrolysis of methyl benzoate. These RSST reaction profiles eliminate the possibility that methanol or methyl benzoate is entrained in the resin beads. This conclusion is supported by GC-MS analysis of organic extracts of Reillexf HPQ that showed only trace quantities of volatile organic compounds.

\subsubsection{Evaluation of the Reactivity of Reillexf HPQ Resin Components.}

The general Reillexf HPQ resin structure $\mathbf{2}$ identifies the repeating polymeric subunits. The reactivity of repeating subunits was evaluated using model compounds. The pyridine ring was expected to be especially chemically inert. First, the N-methyl functional group on the pyridine repeating unit was oxidizing using the bis- $\mathrm{N}$ methylpyridine 7 . No reaction was observed in 8 molar nitric acid at $90 \mathrm{oC}$, evidence the

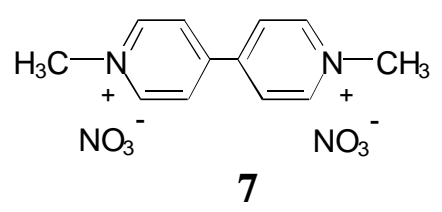

$\mathrm{N}$-methylpyridine groups in Reillexf HPQ are not responsible for the low-temperature exotherm. In addition, the pyridine groups were shown to be unreactive with nitric acid, as expected.

To evaluate the reactivity of the unreacted cross-linking agent, divinylbenzene, the styrene reaction with 8 molar nitric acid was studied in the RSST (Figure 42). A peak self-heating rates occurred at about $107{ }^{\circ} \mathrm{C}$ for the reaction with styrene, significantly higher that the low-temperature exotherm.

The reactivity of the ethylbenzene pendant group (a polymeric subunit) was evaluated. These ethylbenzene functional groups were introduced into the resin structure as an impurity during production. According to Reilly Industries Inc., the cross-linking agent, 
divinylbenzene, used in Reillexf HPQ production actually contains about 20-25\% ethylvinylbenzene. Only one end of the ethylvinylbenzene molecule polymerizes during the cross-linking process, creating the ethylbenzene pendant groups in Reillexf HPQ. Diethylbenzene was used as a model compound for the ethylbenzene pendant group. RSST tests with biphasic mixtures (liquid-liquid) of diethylbenzene and 8 molar nitric acid are shown in Figure 43. A low-temperature exothermic reaction is observed that varies as a function of concentration. If ethylbenzene pendant groups are responsible for the low-temperature exotherm, we would expect the reaction to occur at higher temperatures for a solid-liquid (resin-nitric acid) reaction than the liquid-liquid reaction (diethylbenzene-nitric acid). In the solid state, the reactive ethyl groups have less surface area exposed to the solvent, leading to fewer molecular collisions. For the solid-liquid reaction, a higher temperature is required to achieve comparable reaction rate to an analogous liquid-liquid reaction. At higher temperatures, the frequency of molecular collisions increases, leading to a greater probability of achieving the energy of activation.

To evaluate whether ethylbenzene pendant groups are responsible for the lowtemperature exotherm, the off-gas reaction products and the solid resin residue were analyzed. GC-MS analysis of the off-gas showed nitric oxide (NO) gas and carbon dioxide $\left(\mathrm{CO}_{2}\right)$ were the predominant products. Due to a limitation of the analytical method, nitrogen dioxide $\left(\mathrm{NO}_{2}\right)$ could not be detected, but was visibly observed as a brown gas. The FTIR of the solid resin residue showed a carbonyl stretching frequency at $1700 \mathrm{~cm}^{-1}$, which was absent in the unreacted resin. This finding is consistent with literature precedents that report the oxidation of ethylbenzene to benzoic acid with variety of oxidizing agents. $8,9,10,11,12,13,14$ However, the oxidative degradation of the polymeric backbone of the resin would also result in similar reaction products.

\subsubsection{Estimation of the Volume of Gas Generated and Average Gas Generation Rate in a 20-Liter Column of Reillexf HPQ Resin and 8 Molar Nitric Acid.}

The balanced chemical equations for two plausible nitric acid reactions are given in equations (1) and (2) below. Both reactions are exothermic and produce gaseous products. In the calculation of the volume of gas generated, we assume all reaction is due to reaction 1 or reaction 2 .

\footnotetext{
${ }^{8}$ S. Yamazaki, “Nickel-catalyzed benzylic oxidation of NaOCl”, Synthetic Communications (1999), 29(13), 2211-2216.

${ }^{9}$ R.L. Holliday, B. Jong, Y.M. Brenton, J.W. Kolis, “Organic Synthesis in subcritical water. Oxidation of alkyl aromatics, Journal of Supercritical Fluids (1998), 12(3), 255-260.

${ }^{10}$ E. Ganin, I. Amer, "Cerium-catalyzed selective oxidation of alkylbenzenes with bromate salts", Synthetic Communications (1995) 25(20), 3149-54.

${ }^{11}$ P. Guiton, S. Menager, O. Lafont, "Permanganic oxidation of ethylbenzene in the presence of quaternary ammonium", Fr. Ann. Pharm. Fr. (1986) Volume Date 1985 43(4), 373-7.

${ }^{12}$ Y.C. Sun, J.M. Winterbottom (Dow Chemical Company), “Oxidation of ethylbenzenes”, US Patent (1973) 72-268824 19720703.

${ }^{13}$ H. Chafwtz, W.D. Blackley, K.L. Kreuz (Texaco Inc.), “Hydrocarbon oxidation with nitric oxide and oxygen”, US Patent (1972) 69-818837 19690423.

14 J.P. Harris (Marathon Oil Corp), “Acetophenone and benzoic acid from ethylbenzene”, US Patent (1966) 19640702.
} 


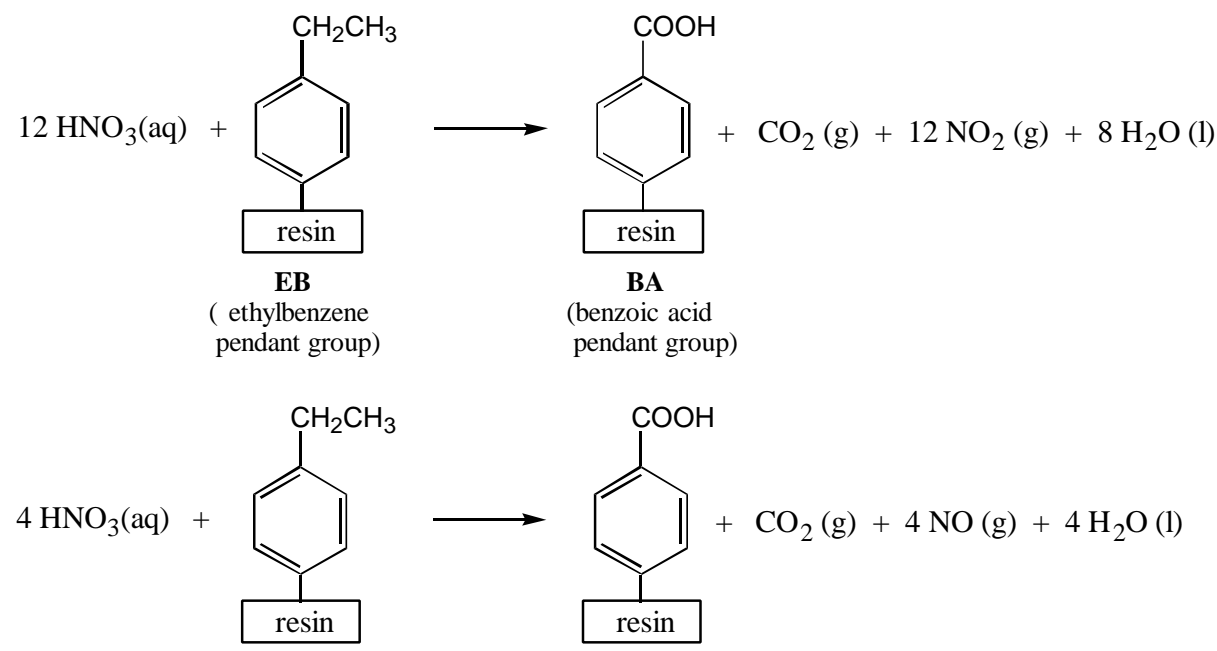

A rough calculation was made to predict the theoretical volume of gas evolved and volumetric gas rates assuming a $20-\mathrm{L}$ volume of resin in nitric acid were heated to initiate the low-temperature exotherm (see equations (3) and (4) in Table 11). This calculation is based on the thermal inertia $(\Phi)$, the enthalpy of reaction $\left(\Delta \mathrm{H}_{\mathrm{rxn}}\right)$, the weighted-average heat capacity of the resin/nitric acid mixture $\left(\mathrm{C}_{\mathrm{v}}\right.$,mix $)$, and the adiabatic temperature rise (ATR) during the RSST test.

First, the thermal inertia was calculated for Reillexf HPQ in 8 molar nitric acid mixtures used in the RSST. The parameters, equations, and result, $\Phi=1.03$, are shown in Table 8 . Second, the $\Delta \mathrm{H}_{\mathrm{rxn}}$ values for the ethylbenzene oxidation reactions (1) and (2) were calculated from enthalpies of formation and are shown in Tables 9 and 10, respectively. This calculation indicates that equation 2 (with the NO product) is 4 times more exothermic than equation 1 (with the $\mathrm{NO}_{2}$ product). Third, the mass of ethylbenzene reacted $\left(\mathrm{m}_{\mathrm{EB}}\right)$ in 20 liters of Reillexf $\mathrm{HPQ}$ as a result of the low-temperature exothermic reaction was calculated as described in Table 11, and the results are presented in Tables 12 and 13. Finally, the mass of ethylbenzene undergoing reaction was converted into volume of gaseous products $(298 \mathrm{~K}, 1 \mathrm{~atm})$, and the volumetric gas generation rate was calculated.

This ATR-based calculation of gas volumes and gas generation rates results in extremely large values. For equation $1\left(\mathrm{NO}_{2}\right.$ product $)$, the calculated maximum volume of gases is about $600 \mathrm{~L} \pm 200$ and the average gas generation rate of $26 \mathrm{~L} / \mathrm{min} \pm 14$. Assuming the more exothermic reaction 2 (NO product) is the only reaction occurring, the calculated maximum volume of gases is about $53 \mathrm{~L} \pm 14$ and the average gas generation rate of 2 $\mathrm{L} / \mathrm{min} \pm 1$. If another more exothermic chemical reaction were occurring, the calculated values for the gas volume and rate would be corresponding smaller.

In contrast, an attempt was made to determine the gas volumes from the experimental pressure change by heating Reillexf HPQ resin in 8 molar nitric acid in the RSST (\#138). The low-temperature exotherm was observed. However, after the sealed Parr bomb returned to room temperature, no net increase in pressure was observed. This $\Delta \mathrm{P}-$ based calculation predicts no net gas volume generated. One explanation for the absence 
of a net pressure change is that the gaseous products generated $\left(\mathrm{NO}, \mathrm{NO}_{2}, \mathrm{CO}_{2}\right.$, and $\left.\mathrm{H}_{2} \mathrm{O}\right)$ recondensed, even under a low backpressure of $11 \mathrm{psig}$. Another explanation is that the $\mathrm{NO}$ generated reacts with nominal $\mathrm{O}_{2}$ in the air present in the RSST, balancing gas generation with gas consumption. Although this experiment to determine a pressure change failed to demonstrate a net pressure increase, off-gas was visually observed during a 60-gram-scale pre-treatment experiment (see Section 5.4.6).

\subsubsection{Pre-treatment of Reillexf HPQ to Eliminate the Low-temperature Exothermic Reaction.}

When 50 grams of Reillexf HPQ resin and 200 grams of 8 molar nitric acid (b.p. about $120{ }^{\circ} \mathrm{C}$ ) were heated to $85{ }^{\circ} \mathrm{C}$ for 30 minutes at ambient pressure in a vacuum oven with a Plexiglas ${ }^{\mathrm{TM}}$ viewing window, the reaction mixture bubbled steadily, and orange $\mathrm{NO}_{\mathrm{x}}$ gases were evolved. The resin changed from the original white to a pale orange-yellow color. After the 30-minute heating period, determined to be sufficient to eliminate the low-temperature exotherm based on small-scale tests, the resin/acid mixture was diluted with water, filtered, washed with water until the eluent possessed a neutral $\mathrm{pH}$, and airdried for 3 days. An additional sample of Reillexf HPQ resin was pretreated for a 45minute heating period following the sample procedure. A sample of both pretreated resins was tested in the RSST, and the low-temperature exotherm was absent (Figure 44). Most importantly, Figure 45 shows that there was no significant pressure increase below $100{ }^{\circ} \mathrm{C}$.

Microscopic analysis showed the pretreated resin beads retained their size and shape, although the color changed from white to pale-yellow. The retention of bead size after the pretreatment was confirmed by comparing the particle size distribution for the untreated and treated Reillexf HPQ as shown in Figure 46. . The performance testing of the treated resin showed that plutonium loading results are comparable to untreated resin, and are described in an another report.

\section{Conclusions}

Resin/nitric acid mixtures were heated in the RSST and the temperature-pressure responses were determined as a function of resin type, nitric acid concentration, cerium(IV) loading, and damage caused by previous irradiation of the resin. Above $100{ }^{\circ} \mathrm{C}$, Reillexf HPQ, irradiated Reillexf HPQ, and Ionacf A-641 showed similar reaction profiles as a function of temperature. Reillexf HPQ showed no obvious inertness to chemical degradation relative to Ionacf A-641. In the irradiated form of Reillexf HPQ, the self-heating rate is a little more erratic than the unirradiated form; however, the runaway behaviors are comparable in intensity and the temperature at which they occur. Below $100{ }^{\circ} \mathrm{C}$, a low intensity, low-temperature exotherm $\left(80{ }^{\circ} \mathrm{C}, 2{ }^{\circ} \mathrm{C} / \mathrm{min}\right)$ was observed only for Reillexf HPQ, suggesting the presence of a small amount of easily-oxidized material.

The effect of cerium(IV) on the resin/nitric acid reactions was evaluated. For Ionacf A 641 and for irradiated Reillexf HPQ, no increase in reactivity was observed in the 
presence of cerium(IV) in 8 and 12 molar nitric acid solutions. For Reillexf HPQ, both cerium(IV)/8 molar nitric acid and 12 molar nitric acid solution produced low intensity pressure rates and self-heating rates that were continuous between the low and hightemperature exothermic reactions, however, the energy released from the lowtemperature exothermic reaction is not sufficient to activate the low-temperature reaction.

Additional testing focused on identifying the origin of the low-temperature exothermic reaction and evaluating its significance with respect to pressure generation. The off-gas products were identified as $\mathrm{NO}, \mathrm{CO}_{2}$, and $\mathrm{NO}_{2}$. An FTIR analysis of the resin residue identified a carbonyl stretching frequency at $1700 \mathrm{~cm}^{-1}$, evidence for the presence of a carboxylic acid. To evaluate the possibility that the ethylbenzene pendant groups of the Reillexf HPQ resin are associated with the exotherm, diethylbenzene, used as a model compound, was heated with nitric acid in the RSST. Indeed, the diethylbenzene- 8 molar nitric acid reaction showed a low-temperature exotherm, and generated $\mathrm{NO}, \mathrm{CO}_{2}, \mathrm{NO}_{2}$, and a mixture of mono- and dicarboxylic acids as reaction products. Furthermore, literature precedents have reported the oxidation of ethylbenzene with various oxidizing agents.

An estimate of the maximum gas volume and gas generation rate was made assuming the low-temperature exotherm occurred on a 20-liter process-scale. While these calculated gas volumes and gas generation rates are extremely large, the experiment showed that after the sealed reaction vessel returned to room temperature, no increase in pressure was observed. However, in a separate experiment, off-gassing of $\mathrm{NO}_{\mathrm{x}}$ was observe during the heating. The large estimates for the gas volumes generated and the experimental observation of $\mathrm{NO}_{\mathrm{x}}$ off-gassing suggest large quantities of gas may be liberated if the ion exchange column temperature approaches 70 to $80{ }^{\circ} \mathrm{C}$.

Finally, a pre-treatment was developed to remove the low-temperature exotherm. The method involves digesting the resin for 45 minutes at $85{ }^{\circ} \mathrm{C}$ at ambient pressure. The low-temperature exotherm was eliminated without changing the size or shape of the resin beads. The performance testing of the treated resin showed that plutonium loading results are comparable to untreated resin, and are described in an another report. 
Table 8. Calculation of the thermal inertia, $\Phi$, for Reillexf HPQ and 8 molar nitric acid mixtures

\begin{tabular}{|c|l|}
\hline $\begin{array}{c}\text { Test } \\
\text { Parameter }\end{array}$ & Definitions \\
\hline $\mathrm{m}_{\mathrm{r}}$ & Mass of resin in an RSST test \\
\hline $\mathrm{m}_{\mathrm{a}}$ & Mass of 8 molar nitric acid solution in an RSST test \\
\hline $\mathrm{m}_{\text {mix }}$ & Mass of resin/8 molar nitric acid mixture in RSST test \\
\hline $\mathrm{m}_{\mathrm{s}}$ & Mass of borosilicate glass RSST test cell \\
\hline$m_{\mathrm{HNO} 3}$ & Molality of nitric acid solution \\
\hline $\mathrm{C}^{\mathrm{o}}$ & Specific heat of the pure solvent (water) \\
\hline $\mathrm{C}_{\mathrm{a}}$ & Specific heat for 8 molar nitric acid \\
\hline $\mathrm{C}_{\mathrm{r}}$ & Specific heat for resin (assumed) \\
\hline $\mathrm{C}_{\mathrm{v}, \text { mix }}$ & Weighted average heat capacity of resin/nitric acid mixture \\
\hline $\mathrm{C}_{\mathrm{s}}$ & Specific heat of borosilicate glass test cell \\
\hline$\Phi_{\mathrm{c}, \mathrm{HNO} 3}$ & Apparent molal heat capacity of the $\mathrm{HNO}_{3}$ in water \\
\hline$\Phi$ & Thermal inertia for RSST test \\
\hline
\end{tabular}

\begin{tabular}{|c|l|}
\hline $\begin{array}{c}\text { Test } \\
\text { Parameter }\end{array}$ & Equations \\
\hline $\mathrm{C}_{\mathrm{v}, \text { mix }}$ & {$\left[\mathrm{m}_{\mathrm{a}} /\left(\mathrm{m}_{\mathrm{a}}+\mathrm{m}_{\mathrm{r}}\right)\right] * \mathrm{C}_{\mathrm{a}}+\left[\mathrm{m}_{\mathrm{r}} /\left(\mathrm{m}_{\mathrm{a}}+\mathrm{m}_{\mathrm{r}}\right) \mathrm{C}_{\mathrm{r}}\right.$} \\
\hline$\Phi$ & $\left(\mathrm{m}_{\mathrm{s}}{ }^{*} \mathrm{C}_{\mathrm{s}}+\mathrm{m}_{\mathrm{b}} * \mathrm{C}_{\mathrm{b}}\right) /\left(\mathrm{m}_{\mathrm{s}}{ }^{*} \mathrm{C}_{\mathrm{s}}\right)$ \\
\hline
\end{tabular}

\begin{tabular}{|c|c|c|c|}
\hline $\begin{array}{c}\text { Test } \\
\text { Parameter }\end{array}$ & Values & Units & Reference \\
\hline $\mathrm{m}_{\mathrm{r}}$ & 2.87 & Grams & \\
\hline $\mathrm{m}_{\mathrm{a}}$ & 7.35 & Grams & \\
\hline$\left[\mathrm{HNO}_{3}\right]$ & 8 & Molar & \\
\hline$m_{\mathrm{HNO} 3}$ & 6.5 & Moles $/ \mathrm{kg}$ & \\
\hline$\Phi_{\mathrm{c}, \mathrm{HNO} 3}$ & 11.40 & $\mathrm{cal} /\left(\mathrm{g}^{\circ} \mathrm{C}\right)$ & 15 \\
\hline $\mathrm{C}^{\mathrm{0}}$ & 1.00 & $\mathrm{cal} /\left(\mathrm{g}^{\circ} \mathrm{C}\right)$ & \\
\hline $\mathrm{MW}_{\mathrm{HNO} 3}$ & 63 & $\mathrm{~g} / \mathrm{mole}$ & \\
\hline $\mathrm{C}_{\mathrm{a}}$ & 1.00 & $\mathrm{cal} /\left(\mathrm{g}^{\circ} \mathrm{C}\right)$ & \\
\hline $\mathrm{C}_{\mathrm{r}}$ & 0.50 & $\mathrm{cal} /\left(\mathrm{g}^{\circ} \mathrm{C}\right)$ & \\
\hline $\mathrm{C}_{\mathrm{v}, \text { mix }}$ & 0.86 & $\mathrm{cal} /\left(\mathrm{g}^{\circ} \mathrm{C}\right)$ & \\
\hline $\mathrm{m}_{\operatorname{mix}}$ & 10.22 & $\mathrm{Grams}$ & \\
\hline $\mathrm{m}_{\mathrm{s}}$ & 1.40 & $\mathrm{Grams}$ & \\
\hline $\mathrm{C}_{\mathrm{s}}$ & 0.19 & $\mathrm{cal} /\left(\mathrm{g}^{\circ} \mathrm{C}\right)$ & 16 \\
\hline$\Phi$ & 1.03 & & \\
\hline
\end{tabular}

${ }^{15}$ Handbook of Chemistry and Physics, $65^{\text {th }}$ Edition, 1984-85, R.C. West, ed., Chemical Rubber Company Press Inc, Boca Raton, Florida, D-123.

${ }^{16}$ Perry's Chemical Engineers' Handbook, $6^{\text {th }}$ Edition, 1984, R.H. Perry and D.W. Green, McGraw-Hill Company, Section 23, page 52. 
Table 9. Calculation of the enthalpy of reaction $\left(\Delta \mathrm{H}_{\mathrm{rxn}, 1}\right)$ for equation $1\left(\mathrm{NO}_{2}\right.$ as product)

\begin{tabular}{|r|c|c|c|}
\hline & $\begin{array}{c}\text { Stoich. } \\
\text { Coeff. }\end{array}$ & $\begin{array}{c}\Delta \mathbf{H}_{\mathbf{f}}{ }^{*} \\
\mathrm{kcal} / \mathrm{mol}\end{array}$ & $\begin{array}{c}\text { Calc'd } \\
\Delta \mathbf{H}_{\mathbf{f}} \\
\mathrm{KJ} / \mathrm{mol}\end{array}$ \\
\hline Reactants: & & & \\
\hline Ethylbenzene (l) & 1 & -3.0 & -12.5 \\
\hline $\mathrm{HNO}_{3}$ (dil. aq) & 12 & -49.6 & -207.4 \\
\hline$\Sigma \Delta \mathrm{H}_{\mathrm{f}}$ (reactants ) & & $\mathbf{- 5 9 8}$ & $\mathbf{- 2 5 0 1}$ \\
Products: & & & \\
\hline Benzoic $\mathrm{Acid}^{(\mathrm{cr})}$ & 1 & -92.0 & -385.1 \\
\hline $\mathrm{CO}_{2}(\mathrm{~g})$ & 1 & -94.1 & -393.5 \\
\hline $\mathrm{NO}_{2}(\mathrm{~g})$ & 12 & 7.9 & 33.2 \\
\hline $\mathrm{H}_{2} \mathrm{O}(\mathrm{l})$ & 8 & -68.3 & -285.8 \\
\hline$\Sigma \Delta \mathrm{H}_{\mathrm{f}}($ products $)$ & & $\mathbf{- 6 3 7}$ & $\mathbf{- 2 6 6 7}$ \\
\hline$\Delta \mathbf{H}_{\text {rxn }}=$ & & $\mathbf{- 4 0}$ & $\mathbf{- 1 6 6}$ \\
\hline
\end{tabular}

Table 10. Calculation of the enthalpy of reaction $\left(\Delta \mathrm{H}_{\mathrm{rxn}, 2}\right)$ for equation 2 (NO as product)

\begin{tabular}{|r|c|c|c|}
\hline & $\begin{array}{c}\text { Stoich. } \\
\text { Coeff. }\end{array}$ & $\begin{array}{c}\Delta \mathbf{H}_{\mathrm{f}}^{*} \\
\mathrm{kcal} / \mathrm{mol}\end{array}$ & $\begin{array}{c}\text { Calc'd } \\
\Delta \mathbf{H}_{\mathrm{f}} \\
\mathrm{KJ} / \mathrm{mol}\end{array}$ \\
\hline Reactants: & & & \\
\hline Ethylbenzene (l) & 1 & -3.0 & -12.5 \\
\hline $\mathrm{HNO}_{3}$ (dil. aq) & 4 & -49.6 & -207.4 \\
\hline$\Sigma \Delta \mathrm{H}_{\mathrm{f}}$ (reactants ) & & $\mathbf{- 2 0 1}$ & $\mathbf{- 8 4 2}$ \\
& & & \\
Products: & & & \\
\hline Benzoic $\mathrm{Acid}_{(\mathrm{cr})}$ & 1 & -92.0 & -385.1 \\
\hline $\mathrm{CO}_{2}(\mathrm{~g})$ & 1 & -94.1 & -393.5 \\
\hline $\mathrm{NO}(\mathrm{g})$ & 4 & 21.6 & 90.2 \\
\hline $\mathrm{H}_{2} \mathrm{O}(\mathrm{l})$ & 4 & -68.3 & -285.8 \\
\hline$\Sigma \Delta \mathrm{H}_{\mathrm{f}}($ products $)$ & & $\mathbf{- 3 7 3}$ & $\mathbf{- 1 5 6 1}$ \\
\hline$\Delta \mathbf{H}_{\mathrm{rxn}}=$ & & $\mathbf{- 1 7 2}$ & $\mathbf{- 7 1 9}$ \\
\hline
\end{tabular}


Table 11. Calculation of the mass of ethylbenzene reacted $\left(m_{E B}\right)$ in 20 liters of Reillexf HPQ as a result of the low-temperature exothermic reaction.

$$
\begin{gathered}
\Delta \mathbf{H}_{\mathrm{rxn}}=-\Phi \mathrm{C}_{\mathrm{v}}(\mathrm{ATR})\left(\mathrm{MW}_{\mathrm{EB}}\right) /\left(\mathrm{m}_{\mathrm{EB}} / \mathrm{m}_{\mathrm{p}}\right) \\
\text { or } \\
\left(\mathbf{m}_{\mathrm{EB}} / \mathbf{m}_{\mathrm{p}}\right)=-\Phi \mathbf{C}_{\mathrm{v}}(\mathrm{ATR})\left(\mathrm{MW}_{\mathrm{EB}}\right) / \Delta \mathbf{H}_{\mathrm{rxn}}
\end{gathered}
$$

\begin{tabular}{|c|c|c|c|c|}
\hline Parameter & Value & Units & Description & Equation/Comment \\
\hline$\Phi$ & 1.02 & Unitless & Thermal inertia & $\left(\mathrm{m}_{\mathrm{s}} * \mathrm{C}_{\mathrm{s}}+\mathrm{m}_{\mathrm{b}} * \mathrm{C}_{\mathrm{b}}\right) /\left(\mathrm{m}_{\mathrm{s}} * \mathrm{C}_{\mathrm{s}}\right)$ \\
\hline $\mathbf{C}_{\mathbf{v}}$ & 0.86 & $\mathrm{Cal} /\left(\mathrm{g} /{ }^{\circ} \mathrm{C}\right)$ & Wt-avg Heat capacity of sample mixture & {$\left[m_{a} /\left(m_{a}+m_{r}\right)\right]^{*} C_{a}+\left[m_{r} /\left(m_{a}+m_{r}\right)\right] * C_{r}$} \\
\hline$\Delta \mathbf{H}_{\mathrm{rxn}, \mathbf{1}}$ & -40 & Kcal/mole & Enthalpy of reaction per mole of $E B$ for (1) & $\Sigma\left(\Delta \mathrm{H}_{\mathrm{f}, \text { products }}-\Delta \mathrm{H}_{\mathrm{f}, \text { reactants }}\right)$ \\
\hline$\Delta \mathbf{H}_{\mathrm{rxn}, 2}$ & -172 & Kcal/mole & Enthalpy of reaction per mole of $E B$ for (2) & $\Sigma\left(\Delta \mathrm{H}_{\mathrm{f}, \text { products }}-\Delta \mathrm{H}_{\mathrm{f}, \text { reactants }}\right)$ \\
\hline $\mathbf{M W}_{\mathbf{E B}}$ & 105 & G/mole & MW for ethylbenzene pendant group & Calculated for $\mathrm{C}_{8} \mathrm{H}_{9}$ \\
\hline ATR & cal'd & ${ }^{\circ} \mathrm{C}$ & Adiabatic temperature rise & $\Delta \mathrm{T}-(\mathrm{IHR}) *(\Delta \mathrm{t})$ \\
\hline$\overline{\mathrm{C}_{\mathrm{r}}}$ & 0.50 & $\mathrm{Cal} /\left(\mathrm{g}^{\circ} \mathrm{C}\right)$ & Heat capacity of Reillexf HPQ resin & Assumed \\
\hline $\mathrm{C}_{\mathrm{a}}$ & 0.9997 & $\mathrm{Cal} /\left(\mathrm{g}^{\circ} \mathrm{C}\right)$ & Heat capacity of 8M nitric acid solution & Literature value \\
\hline $\mathrm{m}_{\mathrm{r}}$ & 2.87 & $\mathrm{~g}$ & Mass of resin in RSST test cell & Experimental \\
\hline $\mathrm{m}_{\mathrm{a}}$ & 7.35 & g & Mass of $8 \mathrm{M} \mathrm{HNO}_{3}$ in RSST test cell & Experimental \\
\hline $\mathrm{m}_{\mathrm{p}}$ & 22.3 & $\mathrm{~kg}$ & Mass of reactants for process-scale & $\mathrm{V}_{\mathrm{p} *} \rho_{\text {resin }}$ \\
\hline IHR & 0.5 & ${ }^{\circ} \mathrm{C} / \mathrm{min}$ & Imposed heating rate & Experimental \\
\hline LTE & & & Low-temperature exotherm & Definition \\
\hline $\mathrm{T}_{\max }$ & Exp'tal & ${ }^{\circ} \mathrm{C}$ & Maximum temperature of LTE & Experimental \\
\hline $\mathrm{T}_{\text {baseline }}$ & Exp'tal & ${ }^{\circ} \mathrm{C}$ & Temperature at which LTE initiates & Experimental \\
\hline$\Delta \mathrm{T}$ & Exp'tal & ${ }^{\circ} \mathrm{C}$ & Experimental temperature change & Local $\mathrm{T}_{\max }-$ Local $\mathrm{T}_{\text {baseline }}$ \\
\hline $\mathrm{t}$ & Exp'tal & $\min$ & Time & Experimental \\
\hline$\Delta \mathrm{t}$ & Exp'tal & $\min$ & Experimental time change & Time $_{\text {local T,max }}-$ Time $_{\text {local } T, \text { baseline }}$ \\
\hline $\mathrm{V}_{\mathrm{p}}$ & 20 & $\mathrm{~L}$ & Volume of reactants for process-scale & Assumed \\
\hline$\rho_{\text {resin }}$ & 1.1151 & $\mathrm{~g} / \mathrm{mL}$ & Density of resin/nitric acid mixture & Experimental - E. Kyser \\
\hline$\left(\mathbf{m}_{\mathrm{EB}} / \mathbf{m}_{\mathrm{p}}\right)$ & cal'd & Unitless & Ratio of "EB reacted" to process mass & $-\Phi \mathbf{C}_{\mathrm{v}}(\mathbf{A T R})\left(\mathbf{M W}_{\mathrm{EB}}\right) / \Delta \mathbf{H}_{\mathrm{rxn}}$ \\
\hline $\mathbf{m}_{\mathrm{EB}}$ & cal'd & $\mathrm{g}$ & Mass of resin/nitric acid mixture that reacts & $\left(m_{E B} / m_{p}\right) *\left(m_{p}\right)$ \\
\hline
\end{tabular}


Table 12. Results of the calculation of the mass of ethylbenzene reacted $\left(\mathrm{m}_{\mathrm{EB}}\right)$ according to equation $1\left(\mathrm{NO}_{2}\right.$ as product)

\begin{tabular}{|c|c|c|c|c|c|c|c|c|}
\hline $\begin{array}{c}\text { Record } \\
\text { Reference } \\
\text { Page No. }\end{array}$ & $\begin{array}{c}\mathbf{T}_{\max } \\
{ }^{\circ} \mathbf{C}\end{array}$ & $\begin{array}{c}a t \\
\mathbf{T} \\
\text { min. }\end{array}$ & $\mathbf{T}_{\text {baseline }}{ }^{\mathbf{0}} \mathbf{C}$ & $\begin{array}{c}a t \\
\mathrm{t} \\
\mathrm{min} .\end{array}$ & ${ }_{{ }^{\Delta}}^{\Delta \mathbf{T}_{\text {exp }}}$ & $\begin{array}{l}\Delta \mathbf{t}_{\text {exp }} \\
\text { min. }\end{array}$ & $\begin{array}{r}\text { Ratio: } \\
\mathbf{m}_{\mathbf{E B}}\end{array}$ & $\begin{array}{c}\mathbf{m}_{\mathrm{EB}} \\
\text { grams }\end{array}$ \\
\hline & & & & & & & $\mathbf{m}_{\mathbf{p}}$ & \\
\hline$\# 115$ & 77.6 & 119.9 & 68.6 & 111.5 & 9.0 & 8.4 & $1.1 \%$ & 244 \\
\hline$\# 135$ & 77.0 & 121.4 & 68.9 & 110.8 & 8.1 & 10.6 & $0.6 \%$ & 145 \\
\hline$\# 137$ & 78.9 & 122.8 & 68.8 & 109.5 & 10.1 & 13.3 & $0.8 \%$ & 178 \\
\hline$\# 143$ & 82.9 & 124.5 & 70.8 & 110.3 & 12.1 & 14.3 & $1.2 \%$ & 257 \\
\hline$\# 191$ & 76.9 & 136.7 & 67.2 & 123.1 & 9.8 & 13.6 & $0.7 \%$ & 153 \\
\hline Average & 79 & 125 & 69 & 113 & 10 & 12 & $0.9 \%$ & 195 \\
\hline Std. Dev . & 3 & 7 & 1 & 6 & 2 & 2 & $0.2 \%$ & 52 \\
\hline Relative Error & $3 \%$ & $5 \%$ & $2 \%$ & $5 \%$ & $15 \%$ & $20 \%$ & $27 \%$ & -- \\
\hline
\end{tabular}

Table 13. Results of the calculation of the mass of ethylbenzene reacted $\left(m_{E B}\right)$ according to equation 2 (NO as product)

\begin{tabular}{|c|c|c|c|c|c|c|c|c|}
\hline $\begin{array}{l}\text { Record } \\
\text { Reference } \\
\text { Page No. }\end{array}$ & $\underset{{ }^{{ }^{\prime}} \mathbf{C a x}}{\operatorname{Ton}}$ & $\begin{array}{c}a t \\
\mathrm{t} \\
\mathrm{min} .\end{array}$ & $\stackrel{\mathbf{T}_{\text {baseline }}}{{ }^{\mathbf{o}} \mathbf{C}}$ & $\begin{array}{c}a t \\
\mathrm{t} \\
\text { min. }\end{array}$ & $\underset{{ }^{0} \mathbf{C}}{\Delta \mathbf{T}_{\exp }}$ & $\begin{array}{l}\Delta \mathbf{t}_{\text {exp }} \\
\text { min. }\end{array}$ & \begin{tabular}{|r|} 
Ratio: \\
$\mathbf{m}_{\mathrm{EB}}$ \\
\end{tabular} & $\underset{\text { grams }}{\mathbf{m}_{\mathrm{EB}}}$ \\
\hline & & & & & & & $\mathbf{m}_{\mathrm{p}}$ & \\
\hline$\# 115$ & 77.6 & 119.9 & 68.6 & 111.5 & 9.0 & 8.4 & $0.3 \%$ & 57 \\
\hline$\# 135$ & 77.0 & 121.4 & 68.9 & 110.8 & 8.1 & 10.6 & $0.2 \%$ & 34 \\
\hline$\# 137$ & 78.9 & 122.8 & 68.8 & 109.5 & 10.1 & 13.3 & $0.2 \%$ & 41 \\
\hline$\# 143$ & 82.9 & 124.5 & 70.8 & 110.3 & 12.1 & 14.3 & $0.3 \%$ & 60 \\
\hline \#191 & 76.9 & 136.7 & 67.2 & 123.1 & 9.8 & 13.6 & $0.2 \%$ & 36 \\
\hline Average $=$ & 79 & 125 & 69 & 113 & 10 & 12 & $0.2 \%$ & 45 \\
\hline Std. Dev $=$ & 3 & 7 & 1 & 6 & 2 & 2 & $0.1 \%$ & 12 \\
\hline Rel. Err. $=$ & $3 \%$ & $5 \%$ & $2 \%$ & $5 \%$ & $15 \%$ & $20 \%$ & $27 \%$ & --- \\
\hline
\end{tabular}


Table 14. Estimation of the volume of gas generated and average gas generation rate in a 20-liter column of Reillexf HPQ and 8 molar nitric acid.

$$
\begin{aligned}
1 \mathrm{~EB}(\mathrm{~s})+12 \mathrm{HNO}_{3}(\mathrm{aq}) & =1 \mathrm{BA}(\mathrm{s})+1 \mathrm{CO}_{2}(\mathrm{~g})+12 \mathrm{NO}_{2}(\mathrm{~g})+8 \mathrm{H}_{2} \mathrm{O}(\mathrm{l}) \\
1 \mathrm{~EB}(\mathrm{~s})+4 \mathrm{HNO}_{3}(\mathrm{aq}) & =1 \mathrm{BA}(\mathrm{s})+1 \mathrm{CO}_{2}(\mathrm{~g})+4 \mathrm{NO}(\mathrm{g})+4 \mathrm{H}_{2} \mathrm{O}(\mathrm{l})
\end{aligned}
$$

\begin{tabular}{|c|c|c|c|c|}
\hline Parameter & Value & Units & Description & Equation or comment \\
\hline $\mathrm{MW}_{\mathrm{EB}}$ & 105 & G/mole & MW for ethylbenzene pendant group & Calculated for $\mathrm{C}_{8} \mathrm{H}_{9}$ \\
\hline $\mathrm{N}_{\mathrm{gas}, 1}$ & 13 & Unitless & $\begin{array}{l}\text { Moles gas produced per mole EB reacted } \\
{\left[1 \text { mole } \mathrm{CO}_{2} \text { plus } 12 \text { moles } \mathrm{NO}_{2}\right]}\end{array}$ & From balanced chemical equation 1 . \\
\hline $\mathrm{N}_{\mathrm{gas}, 2}$ & 5 & Unitless & $\begin{array}{l}\text { Moles gas produced per mole EB reacted } \\
{\left[1 \text { mole } \mathrm{CO}_{2} \text { plus } 4 \text { moles } \mathrm{NO}_{2}\right]}\end{array}$ & From balanced chemical equation 2 . \\
\hline$\overline{\mathrm{R}}$ & 0.0821 & L'atm/(K’mol) & Universal gas constant & \\
\hline $\mathrm{T}$ & 298 & $\mathrm{~K}$ & Temperature for gas volume calculation & \\
\hline$P$ & 1 & Atm & Pressure for gas volume calculation & \\
\hline $\mathrm{m}_{\mathrm{EB}}$ & cal'd & $\mathrm{g}$ & Mass of ethylbenzene reacting & \\
\hline $\mathrm{n}_{\mathrm{EB}}$ & cal'd & Moles & Moles of ethylbenzene present in resin & $\mathrm{m}_{\mathrm{EB}} /\left(\mathrm{MW}_{\mathrm{EB}}\right)$ \\
\hline $\mathrm{n}_{\mathrm{gas}}$ & cal'd & Moles & Maximum moles of $\mathrm{NO}_{2}$ generated & $\mathrm{n}_{\mathrm{EB}} * \mathrm{~N}_{\mathrm{gas}, \mathrm{x}}$, where $\mathrm{x}=1$ or 2 \\
\hline$\overline{V_{\text {gas }}}$ & cal'd & $\mathrm{L}$ & $\begin{array}{l}\text { Maximum volume of gas generated } \\
\text { Under ambient conditions: } 298 \mathrm{~K}, 1 \mathrm{~atm}\end{array}$ & $\mathrm{n}_{\mathrm{gas}} \mathrm{R} \cdot \mathrm{T} / \mathrm{P}$ \\
\hline
\end{tabular}

Calculation according to equation 1.

\begin{tabular}{|c|c|c|c|c|c|c|}
\hline $\begin{array}{c}\text { Record } \\
\text { Reference } \\
\text { Page No. }\end{array}$ & $\begin{array}{c}\mathbf{m}_{\mathrm{EB}} \\
\mathbf{g}\end{array}$ & $\begin{array}{c}\mathbf{n}_{\mathrm{EB}} \\
\mathbf{m o l}\end{array}$ & $\begin{array}{c}\mathbf{m}_{\text {gas }} \\
\mathbf{m o l}\end{array}$ & $\begin{array}{c}\text { Process-scale } \\
\mathbf{V}_{\text {gas }} \\
\mathbf{L}\end{array}$ & $\begin{array}{c}\text { Rxn } \\
\text { Period, } \\
\Delta \mathbf{t}(\mathbf{m i n})\end{array}$ & $\begin{array}{c}\text { Avg. } \\
\Delta \mathbf{V} / \Delta \mathbf{T} \\
\mathbf{L} / \mathbf{m i n}\end{array}$ \\
\hline$\# 115$ & 244 & 2.3 & 30 & 740 & 15 & 49 \\
\hline$\# 135$ & 145 & 1.4 & 18 & 438 & 27 & 16 \\
\hline$\# 137$ & 178 & 1.7 & 22 & 538 & 25 & 21 \\
\hline$\# 143$ & 257 & 2.4 & 32 & 777 & 30 & 26 \\
\hline$\# 191$ & 153 & 1.5 & 19 & 462 & 30 & 15 \\
\hline Avg. & 195 & 1.9 & 24 & $\mathbf{5 9 1}$ & 25 & $\mathbf{2 6}$ \\
\hline Std. Dev. & 52 & 0.5 & 6 & $\mathbf{1 5 8}$ & 6 & $\mathbf{1 4}$ \\
\hline
\end{tabular}

Calculation according to equation 2.

\begin{tabular}{|c|c|c|c|c|c|c|}
\hline $\begin{array}{c}\text { Record } \\
\text { Reference } \\
\text { Page No. }\end{array}$ & $\begin{array}{c}\mathbf{m}_{\text {EB }} \\
\mathbf{g}\end{array}$ & $\begin{array}{c}\mathbf{n}_{\text {EB }} \\
\mathbf{m o l}\end{array}$ & $\begin{array}{c}\mathbf{m}_{\text {gas }} \\
\mathbf{m o l}\end{array}$ & $\begin{array}{c}\text { Process-scale } \\
\mathbf{V}_{\text {gas }} \\
\mathbf{L}\end{array}$ & $\begin{array}{c}\text { Rxn } \\
\text { Period, } \\
\Delta \mathbf{t}(\mathbf{m i n})\end{array}$ & $\begin{array}{c}\text { Avg. } \\
\Delta \mathbf{V} / \Delta \mathbf{T} \\
\mathbf{L} / \mathbf{m i n}\end{array}$ \\
\hline$\# 115$ & 57 & 0.5 & 2.7 & 66 & 15 & 4.4 \\
\hline$\# 135$ & 34 & 0.3 & 1.6 & 39 & 27 & 1.5 \\
\hline$\# 137$ & 41 & 0.4 & 2.0 & 48 & 25 & 1.9 \\
\hline$\# 143$ & 60 & 0.6 & 2.8 & 69 & 30 & 2.4 \\
\hline$\# 191$ & 36 & 0.3 & 1.7 & 41 & 30 & 1.4 \\
\hline Avg. & 45 & 0.4 & 2.2 & $\mathbf{5 3}$ & 25 & $\mathbf{2 . 3}$ \\
\hline Std. Dev. & 12 & 0.1 & 0.6 & $\mathbf{1 4}$ & 6 & $\mathbf{1 . 2}$ \\
\hline
\end{tabular}




\section{Figures}




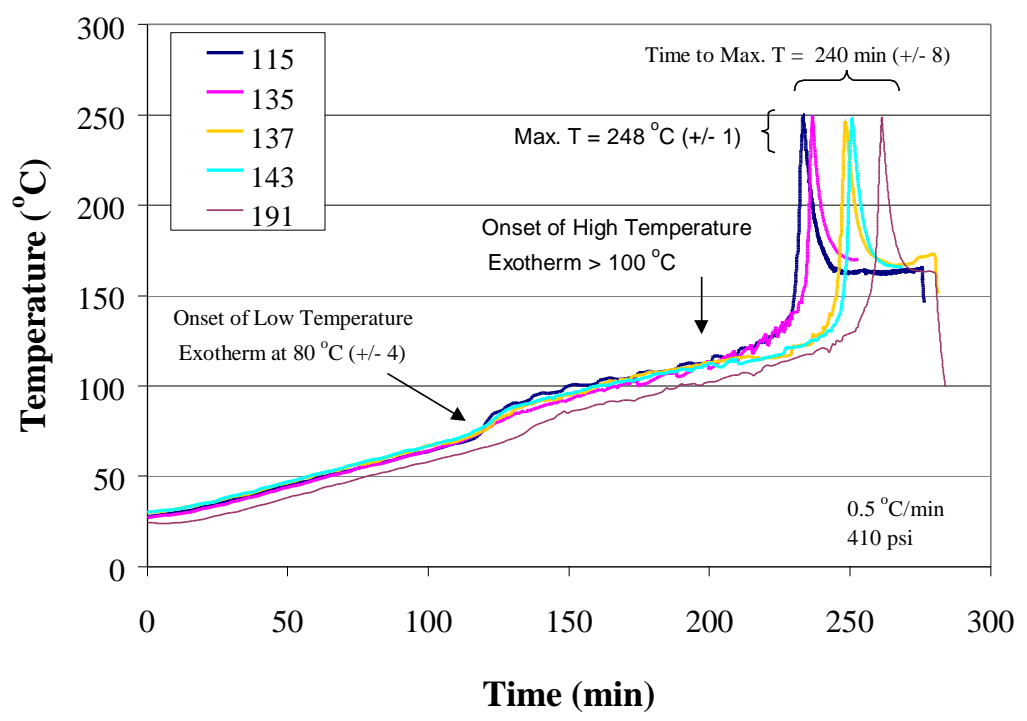

Figure 1. RSST Reproducibility Tests of Reillexf $\mathrm{HPQ}$ in $8 \mathrm{M} \mathrm{HNO}_{3}$ : Temperature $\left({ }^{\circ} \mathrm{C}\right)$ vs. Time (min)

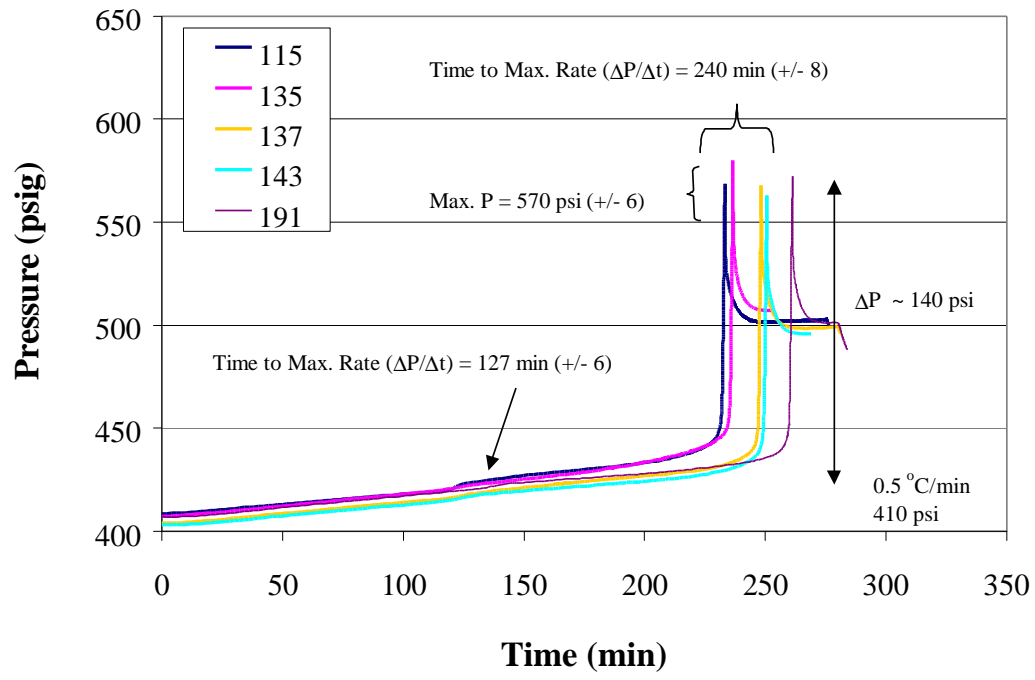

Figure 2. RSST Reproducibility Tests of Reillexf $\mathrm{HPQ}$ in $8 \mathrm{M} \mathrm{HNO}_{3}$ : Pressure (psig) vs. Time (min) 


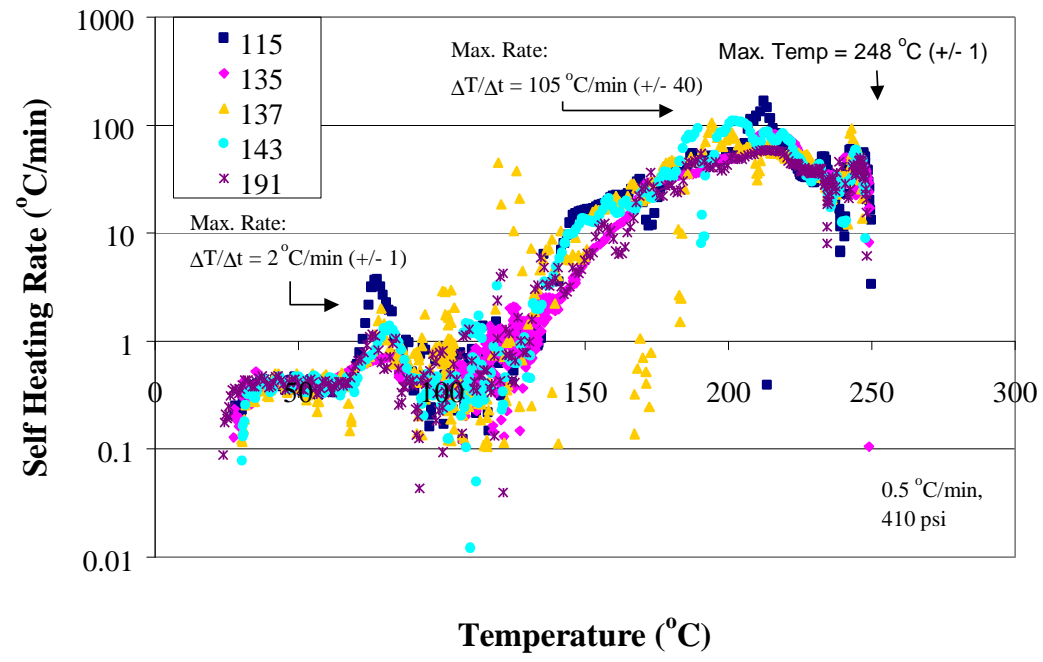

Figure 3. RSST Reproducibility Tests of Reillexf $\mathrm{HPQ}$ in $8 \mathrm{M} \mathrm{HNO}_{3}$ : Self-Heating Rate $\left({ }^{\circ} \mathrm{C} / \mathrm{min}\right)$ vs Temperature $\left({ }^{\circ} \mathrm{C}\right)$

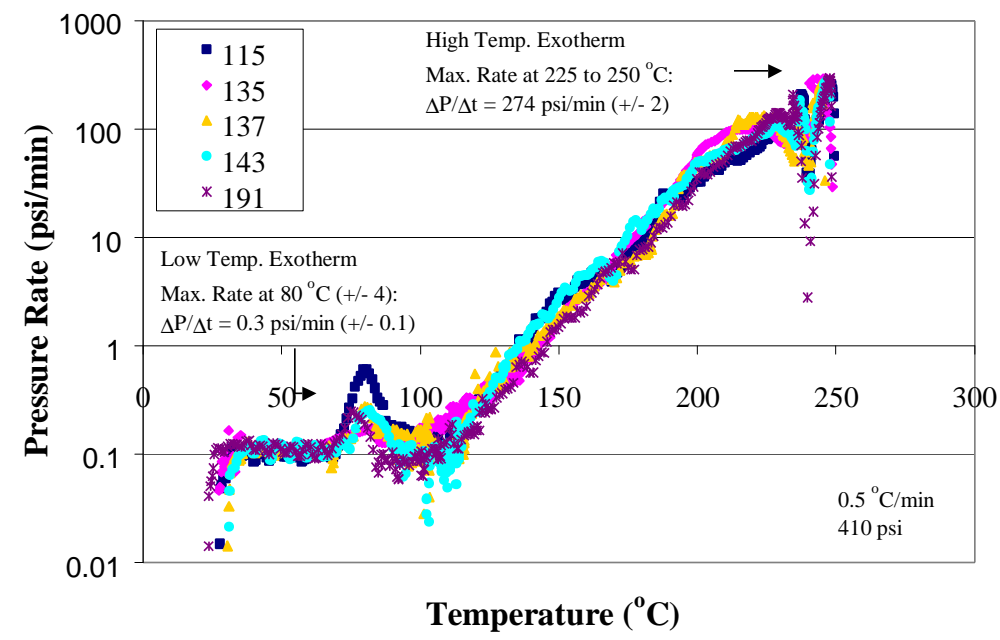

Figure 4. RSST Reproducibility Tests of Reillexf $\mathrm{HPQ}$ in $8 \mathrm{M} \mathrm{HNO}_{3}$ : Pressure Rate (psig/min) vs. Temperature $\left({ }^{\circ} \mathrm{C}\right)$ 


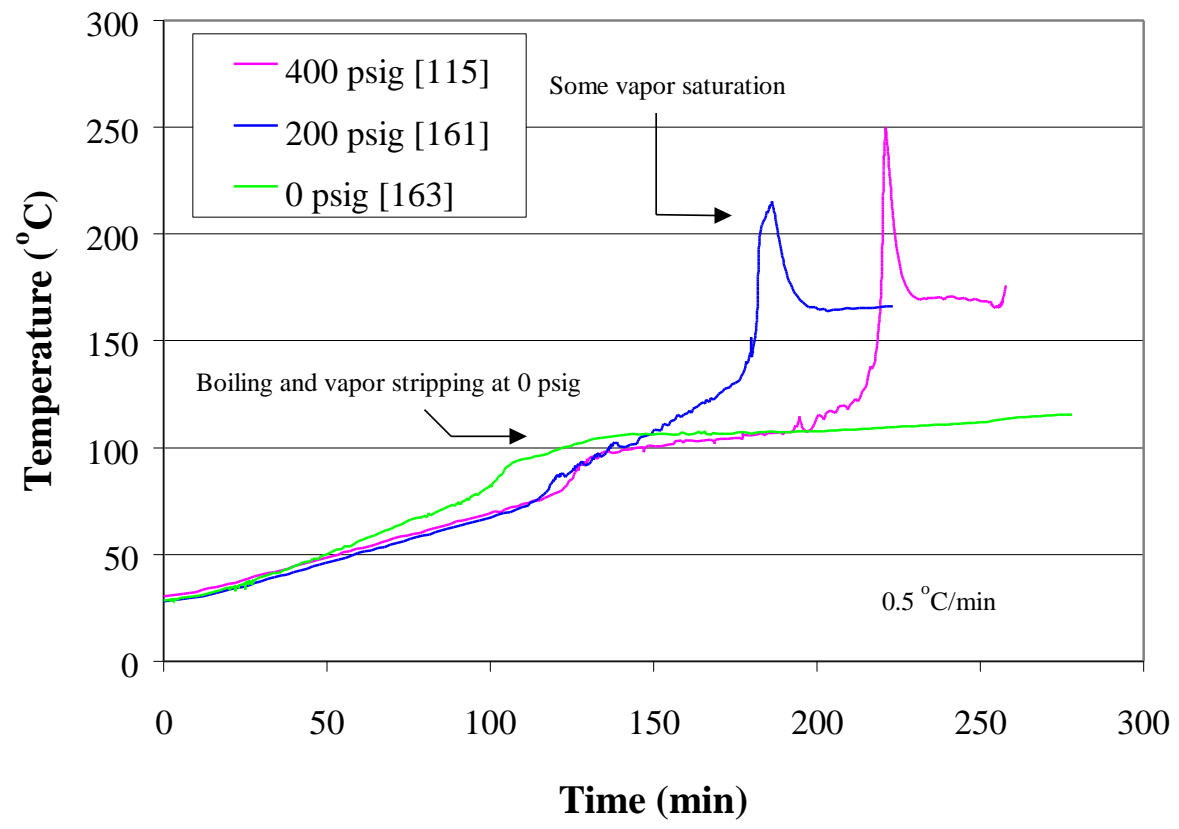

Figure 5. RSST Backpressure Variation Test of Reillexf Resin in $8 \mathrm{M} \mathrm{HNO}_{3}$ : Temperature $\left({ }^{\circ} \mathrm{C}\right)$ vs. Time (min)

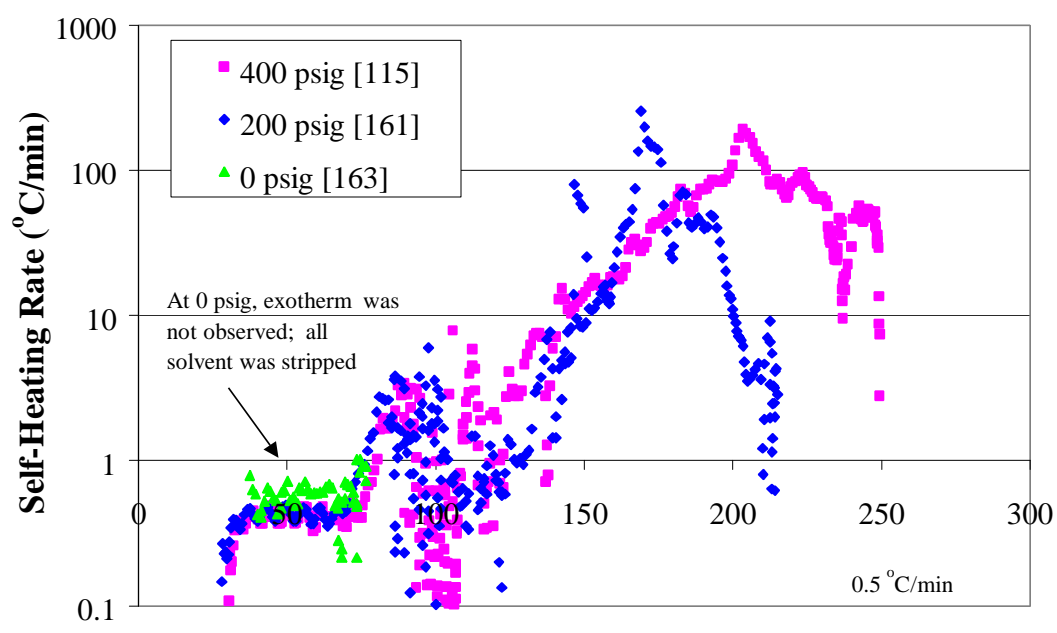

Temperature $\left({ }^{\circ} \mathrm{C}\right)$

Figure 6. RSST Backpressure Variation Test of Reillexf Resin in $8 \mathrm{M} \mathrm{HNO}_{3}$ : Self-Heating Rate $\left({ }^{\circ} \mathrm{C} / \mathrm{min}\right)$ vs. Temperature $\left({ }^{\circ} \mathrm{C}\right)$ 


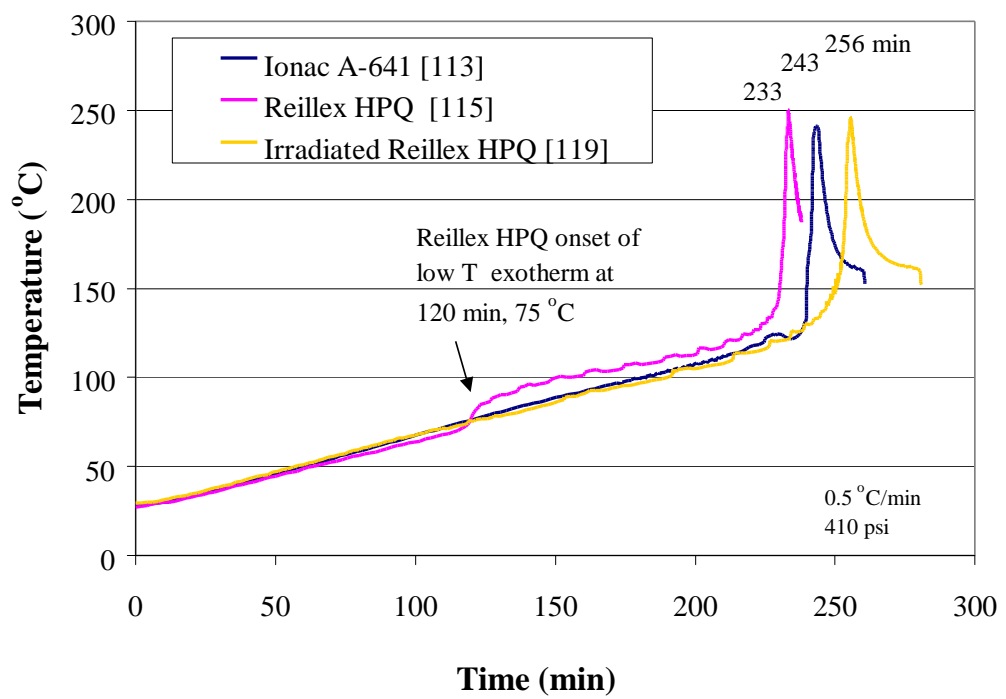

Figure 7. RSST Resin Comparison Tests in $8 \mathrm{M} \mathrm{HNO}_{3}$ : Temperature $\left({ }^{\circ} \mathrm{C}\right)$ vs. Time $(\mathrm{min})$

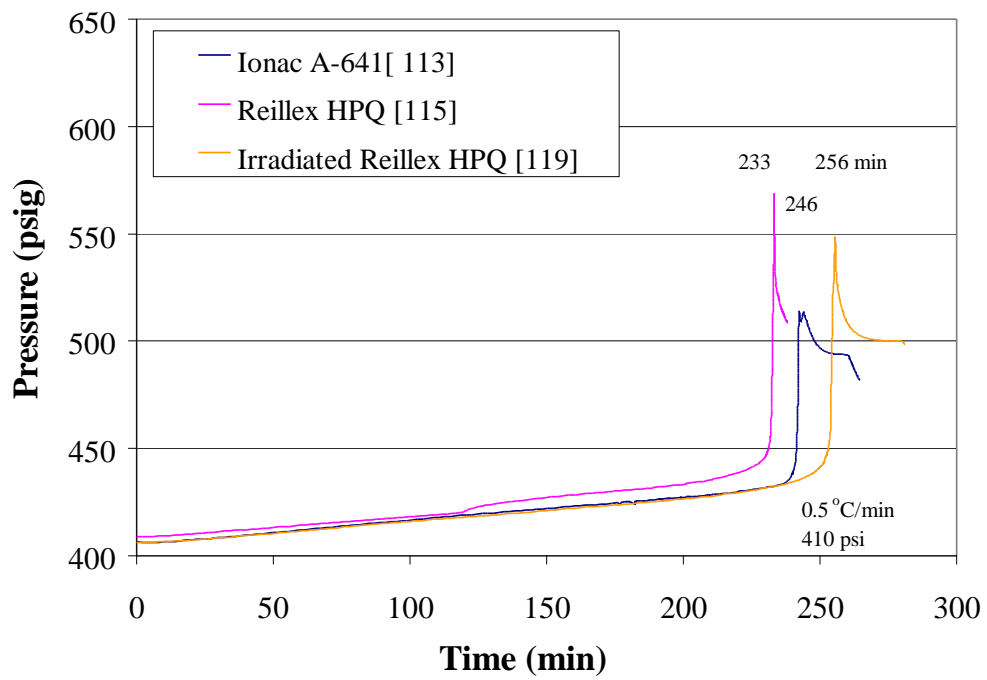

Figure 8. RSST Resin Comparison Tests in $8 \mathrm{M} \mathrm{HNO}_{3}$ : Pressure (psig) vs. Time (min) 


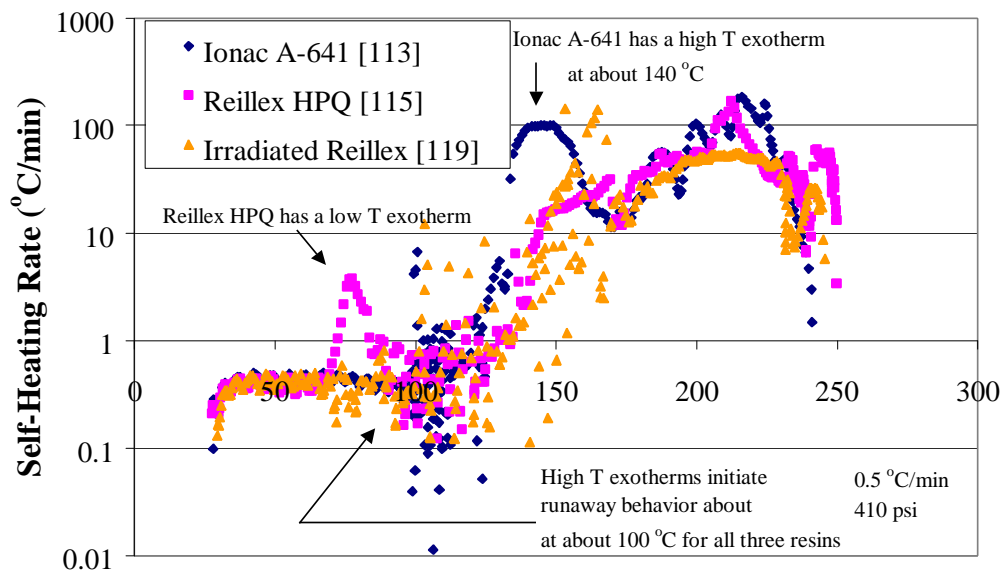

Temperature $\left({ }^{\circ} \mathrm{C}\right)$

Figure 9. RSST Resin Comparison Tests in $8 \mathrm{M} \mathrm{HNO}_{3}$ : Self-heating rate $\left({ }^{\circ} \mathrm{C} / \mathrm{min}\right)$ vs. Temperature $\left({ }^{\circ} \mathrm{C}\right)$

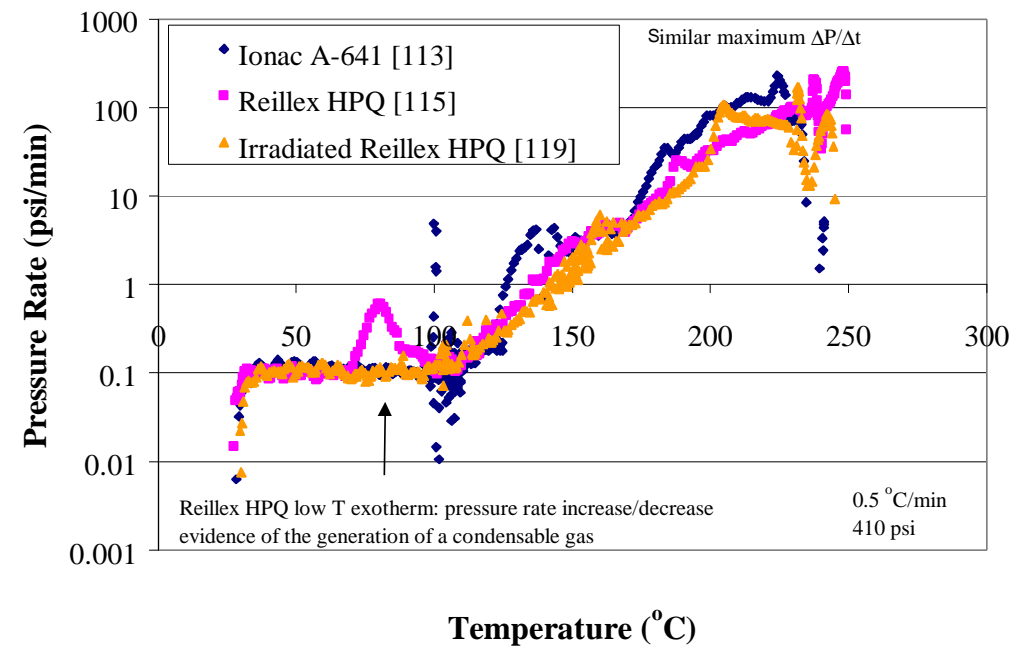

Figure 10. RSST Resin Comparison Tests in $8 \mathrm{M} \mathrm{HNO}_{3}$ : Pressure Rate (psi/min) vs. Temperature $\left({ }^{\circ} \mathrm{C}\right)$ 


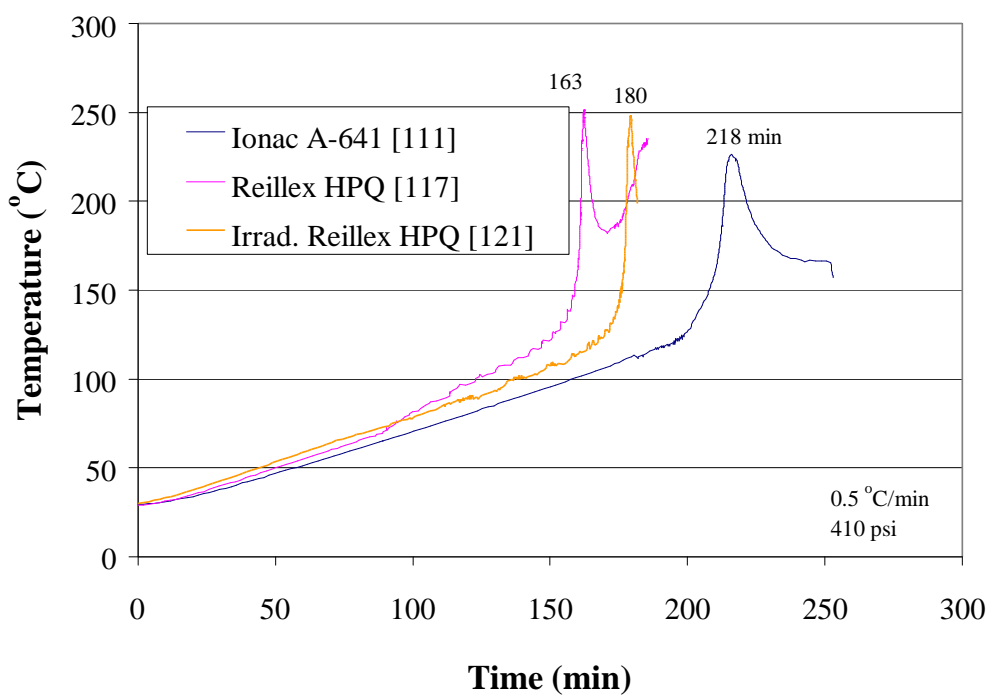

Figure 11. RSST Resin Comparison Tests in $12 \mathrm{M} \mathrm{HNO}_{3}$ : Temperature $\left({ }^{\circ} \mathrm{C}\right)$ vs. Time (min)

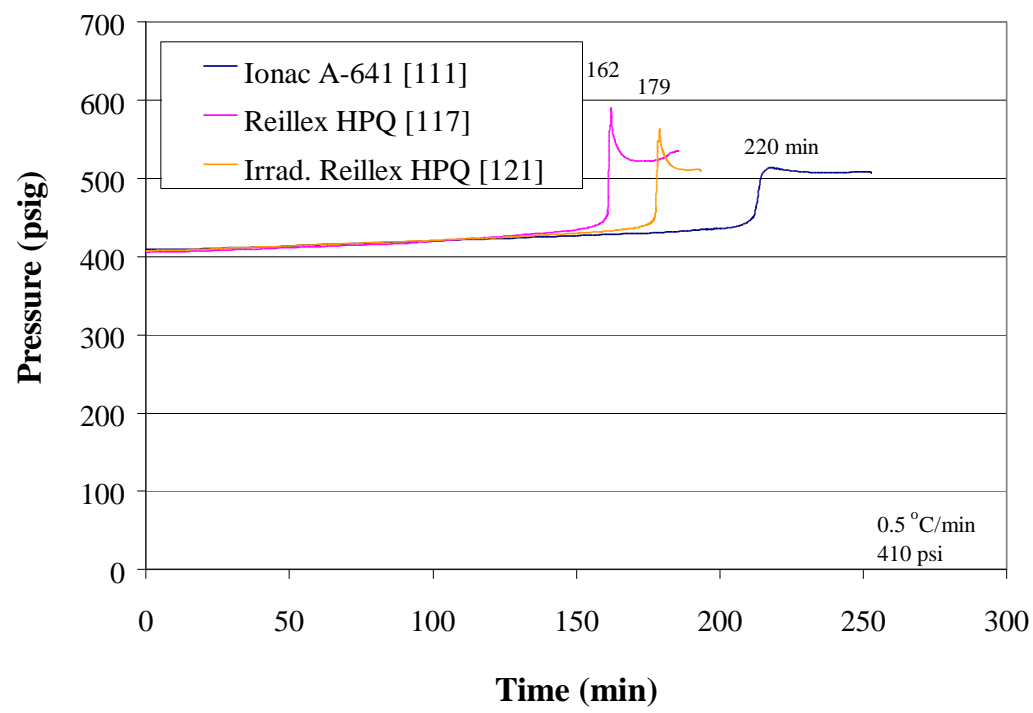

Figure 12. RSST Resin Comparison Tests in $12 \mathrm{M} \mathrm{HNO}_{3}$ : Pressure (psig) vs. Time (min) 


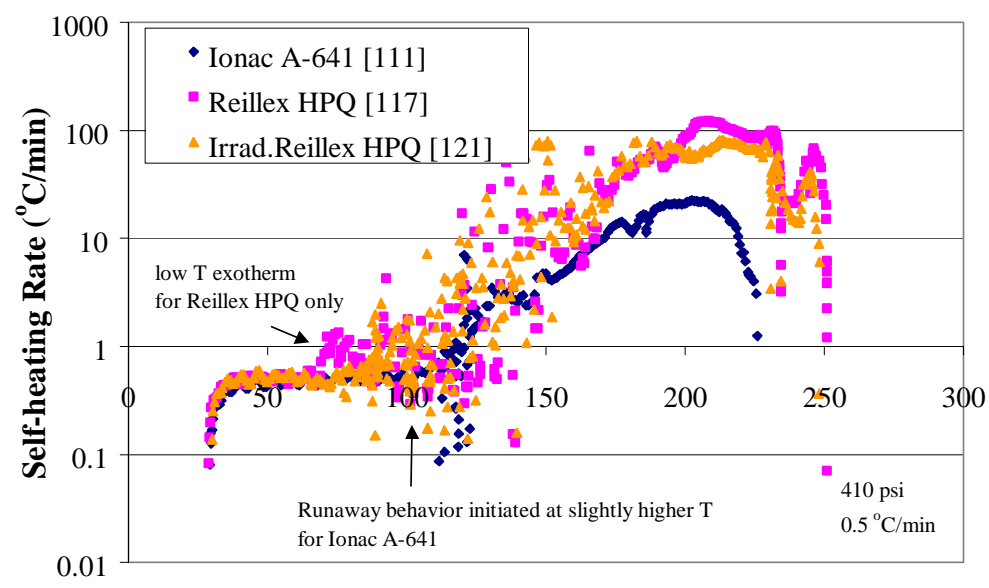

Temperature $\left({ }^{\circ} \mathrm{C}\right)$

Figure 13. RSST Resin Comparison Tests in $12 \mathrm{M} \mathrm{HNO}_{3}$ : Self-heating rate $\left({ }^{\circ} \mathrm{C} / \mathrm{min}\right)$ vs. Temperature $\left({ }^{\circ} \mathrm{C}\right)$

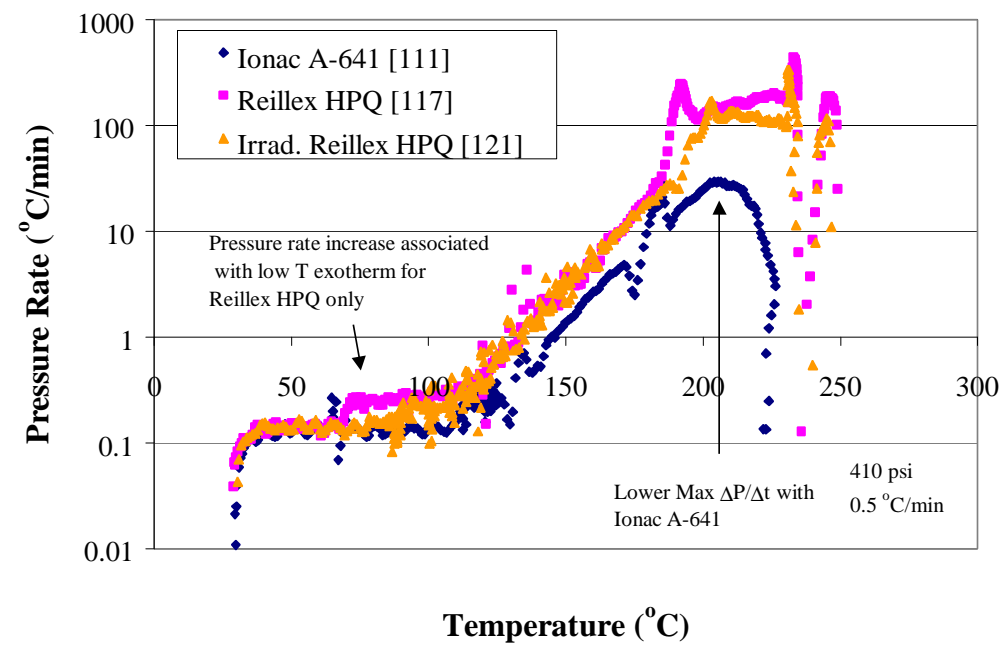

Figure 14. RSST Resin Comparison Tests in $12 \mathrm{M} \mathrm{HNO}_{3}$ : Pressure Rate (psi/min) vs. Temperature $\left({ }^{\circ} \mathrm{C}\right)$ 


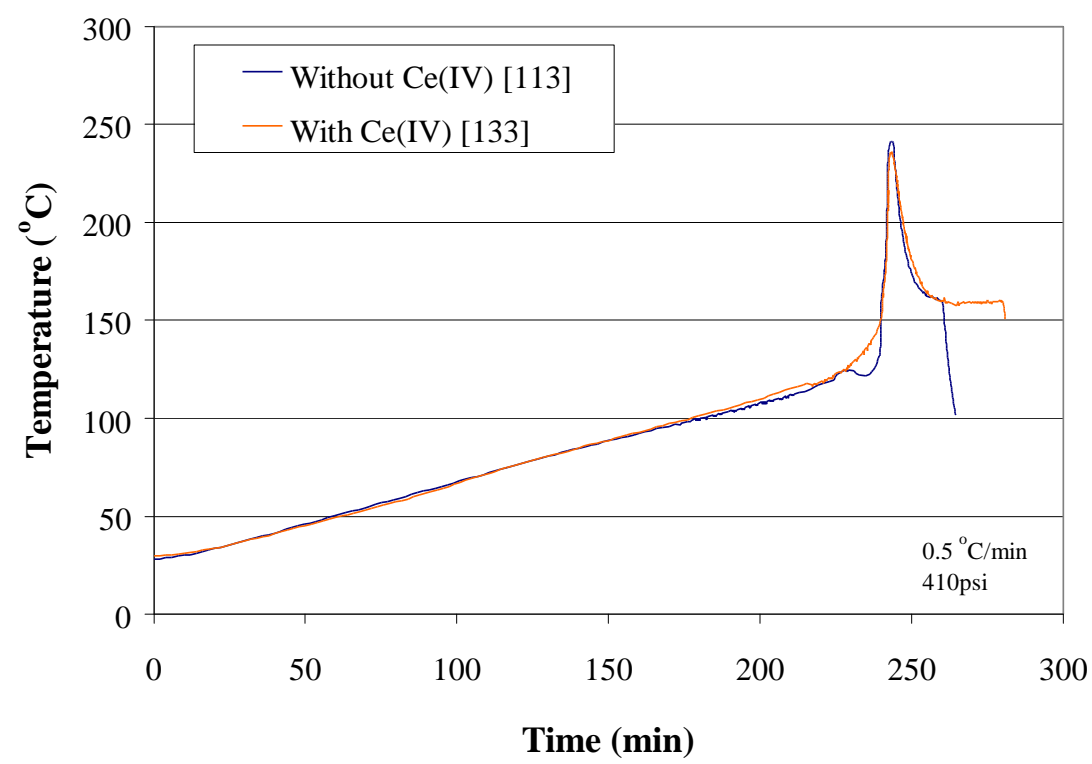

Figure 15. RSST Test of the Effect of $\mathrm{Ce}(\mathrm{IV})$ on Ionacf A-641 in $8 \mathrm{M} \mathrm{HNO}_{3}$ : Temperature $\left({ }^{\circ} \mathrm{C}\right)$ vs. Time (min)

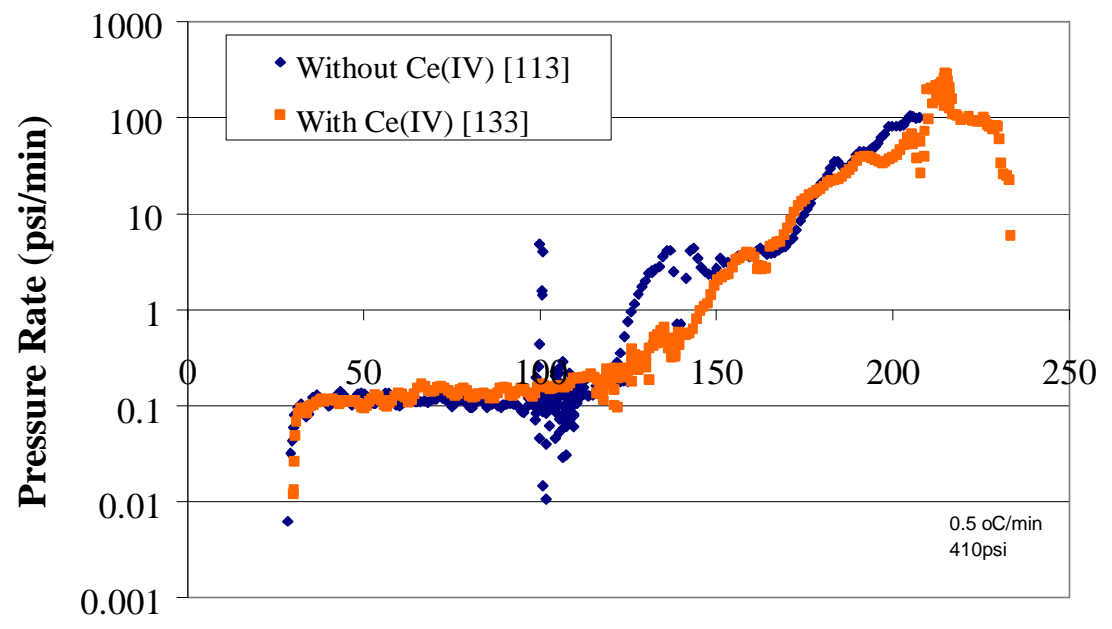

Temperature $\left({ }^{\circ} \mathrm{C}\right)$

Figure 16. RSST Test of the Effect of $\mathrm{Ce}(\mathrm{IV})$ on Ionacf A-641 in $8 \mathrm{M} \mathrm{HNO}_{3}$ : Pressure Rate $\left({ }^{\circ} \mathrm{C} / \mathrm{min}\right)$ vs. Temperature $\left({ }^{\circ} \mathrm{C}\right)$ 


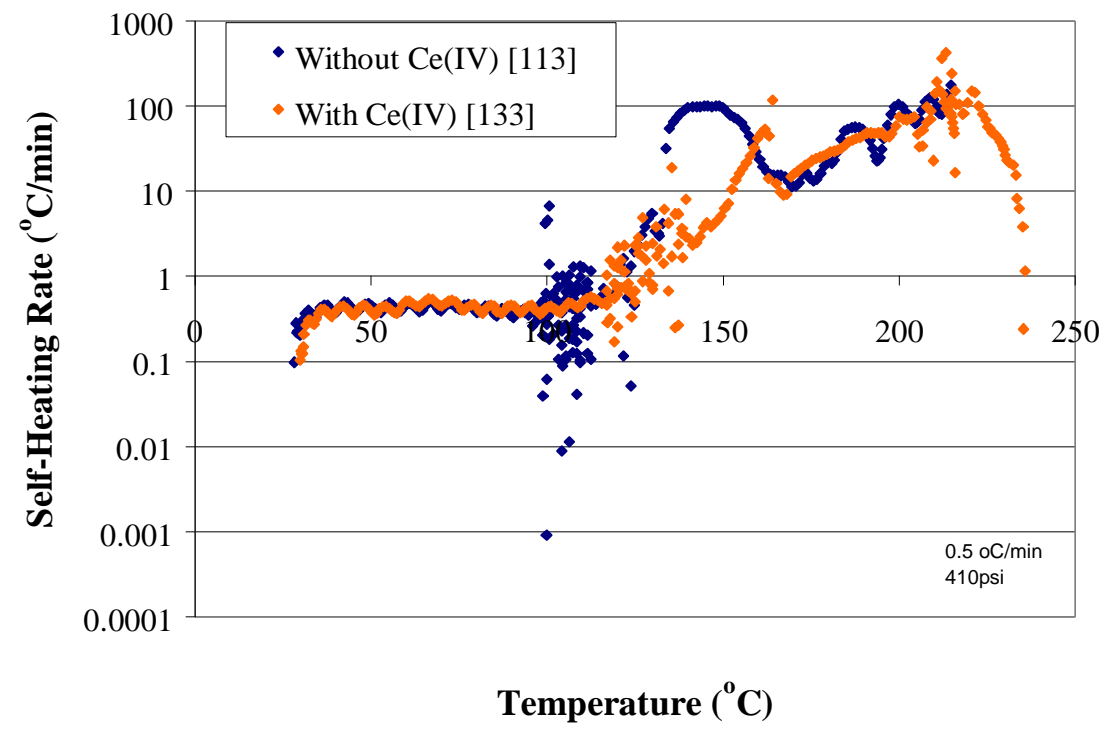

Figure 17. RSST Test of the Effect of Ce(IV) on Ionacf A-641 in $8 \mathrm{M} \mathrm{HNO}_{3}$ : Self-heating Rate $\left({ }^{\circ} \mathrm{C} / \mathrm{min}\right)$ vs. Temperature $\left({ }^{\circ} \mathrm{C}\right)$

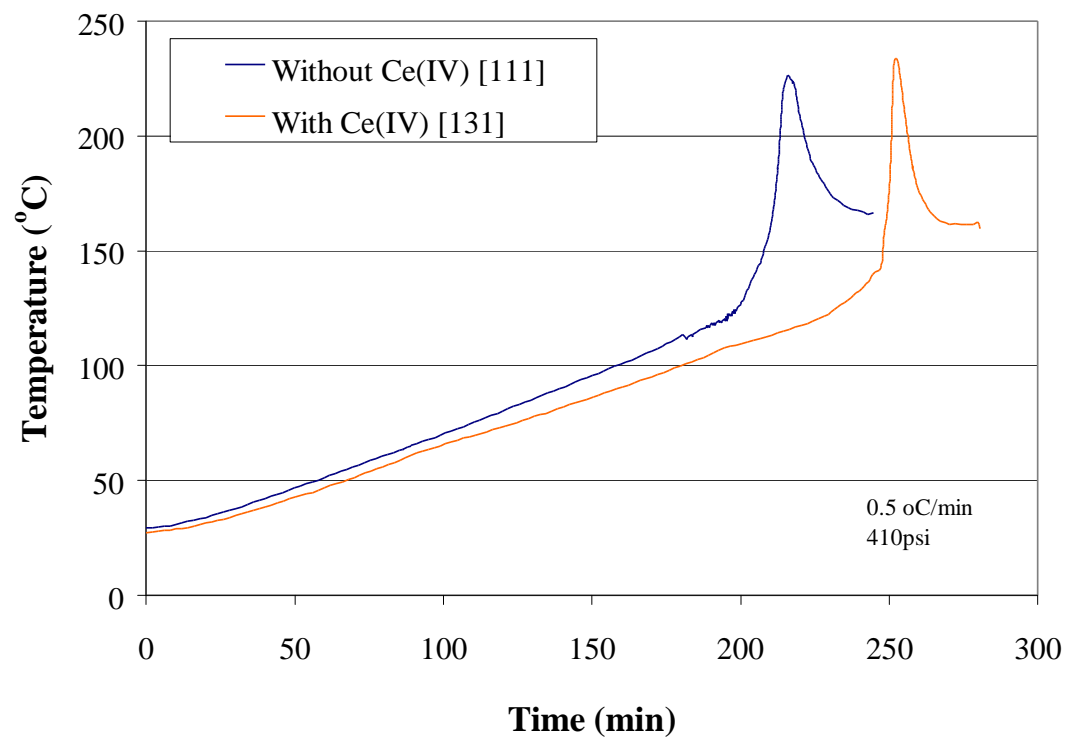

Figure 18. RSST Test of the Effect of $\mathrm{Ce}(\mathrm{IV})$ Test on Ionacf A-641 in $12 \mathrm{M} \mathrm{HNO}_{3}$ : Temperature $\left({ }^{\circ} \mathrm{C}\right)$ vs. Time (min) 


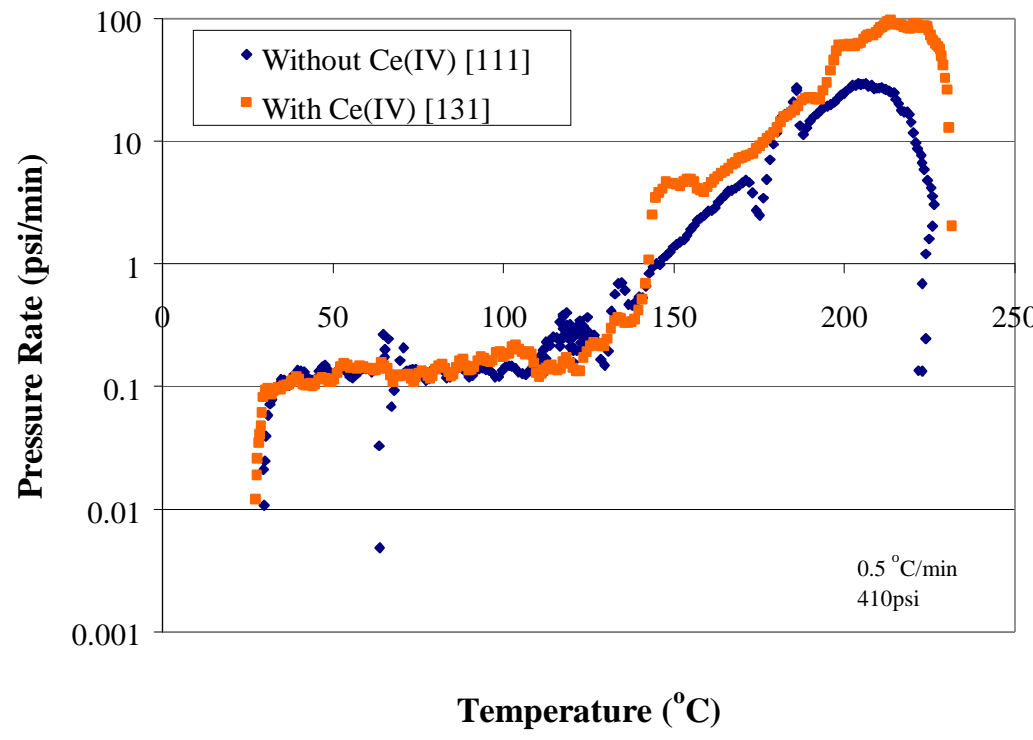

Figure 19. RSST Test of the Effect of $\mathrm{Ce}(\mathrm{IV})$ on Ionacf $\mathrm{A}-641$ in $12 \mathrm{M} \mathrm{HNO}_{3}$ : Pressure Rate (psi/min) vs. Temperature $\left({ }^{\circ} \mathrm{C}\right)$

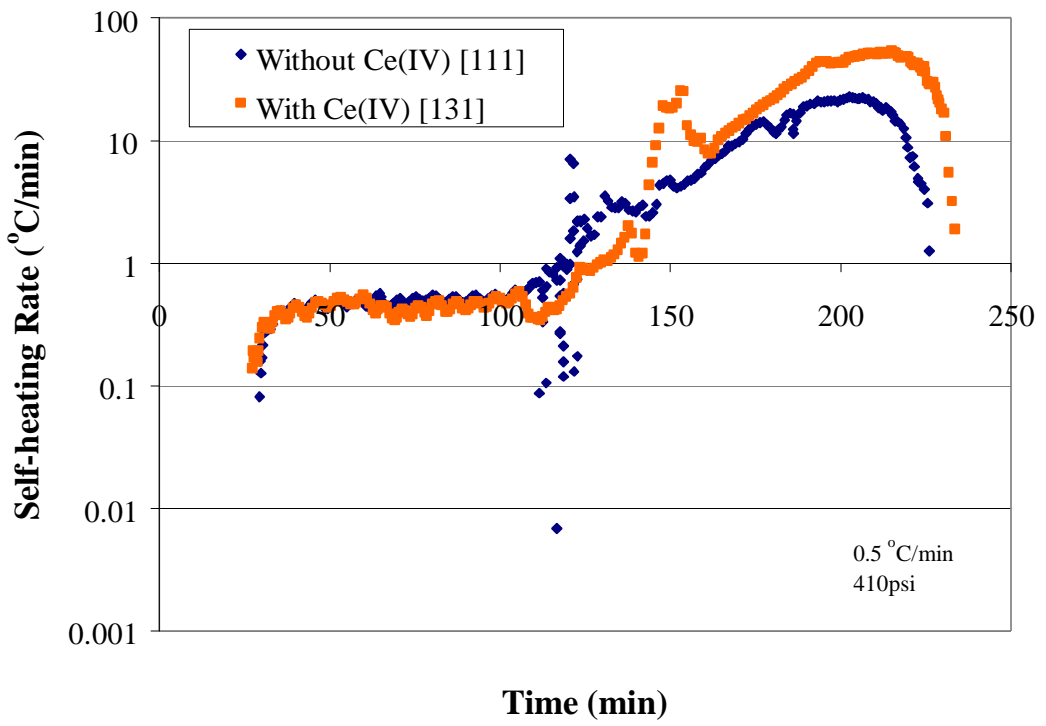

Figure 20. RSST Test of the Effect of $\mathrm{Ce}(\mathrm{IV})$ on Ionacf $\mathrm{A}-641$ in $12 \mathrm{M} \mathrm{HNO}_{3}$ : Self-heating Rate $\left({ }^{\circ} \mathrm{C} / \mathrm{min}\right)$ vs. Temp $\left({ }^{\circ} \mathrm{C}\right)$ 


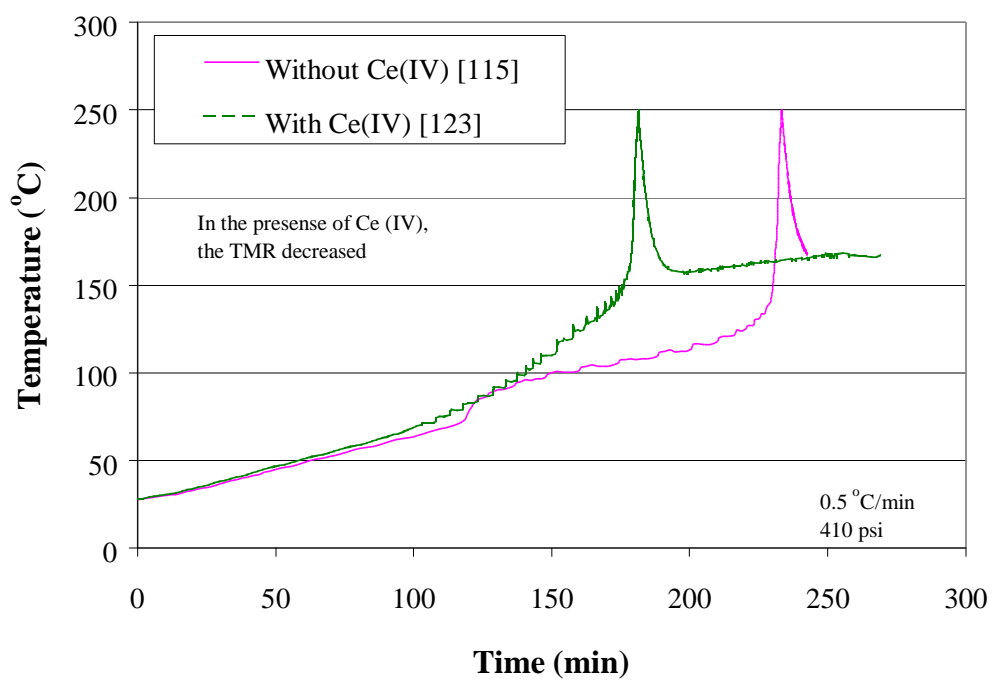

Figure 21. RSST Test of the Effect of $\mathrm{Ce}(\mathrm{IV})$ on Reillexf $\mathrm{HPQ}$ in $8 \mathrm{M} \mathrm{HNO}_{3}$ : Temperature $\left({ }^{\circ} \mathrm{C}\right)$ vs. Time (min)

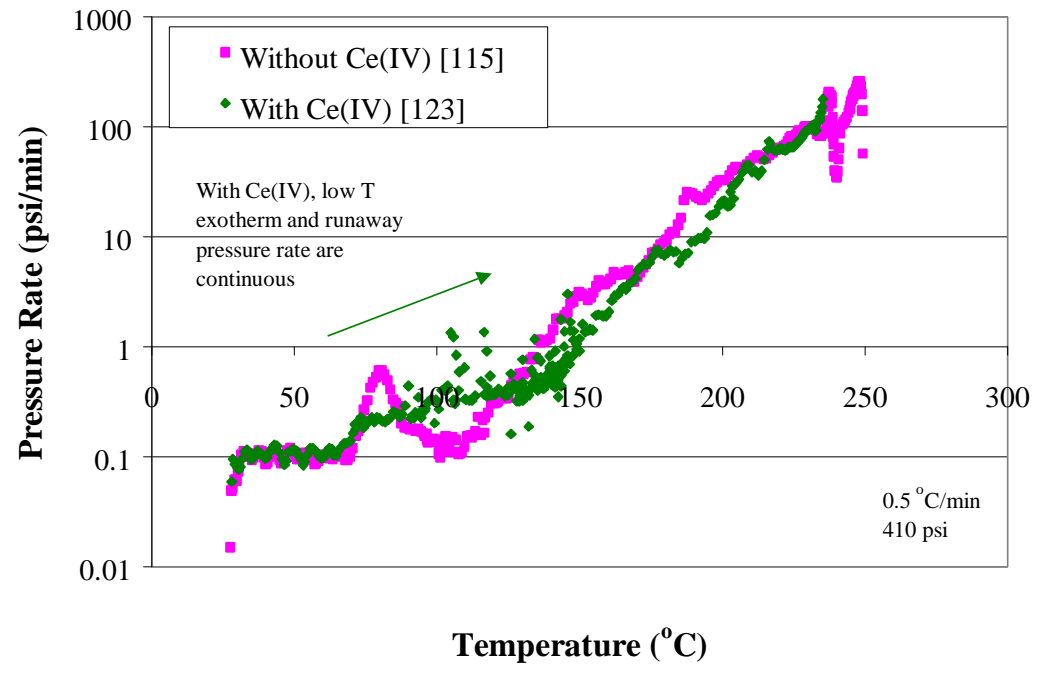

Figure 22. RSST Test of the Effect of $\mathrm{Ce}(\mathrm{IV})$ on Reillexf Resin in $8 \mathrm{M} \mathrm{HNO}_{3}$ : Pressure Rate (psi/min) vs. Temperature $\left({ }^{\circ} \mathrm{C}\right)$ 


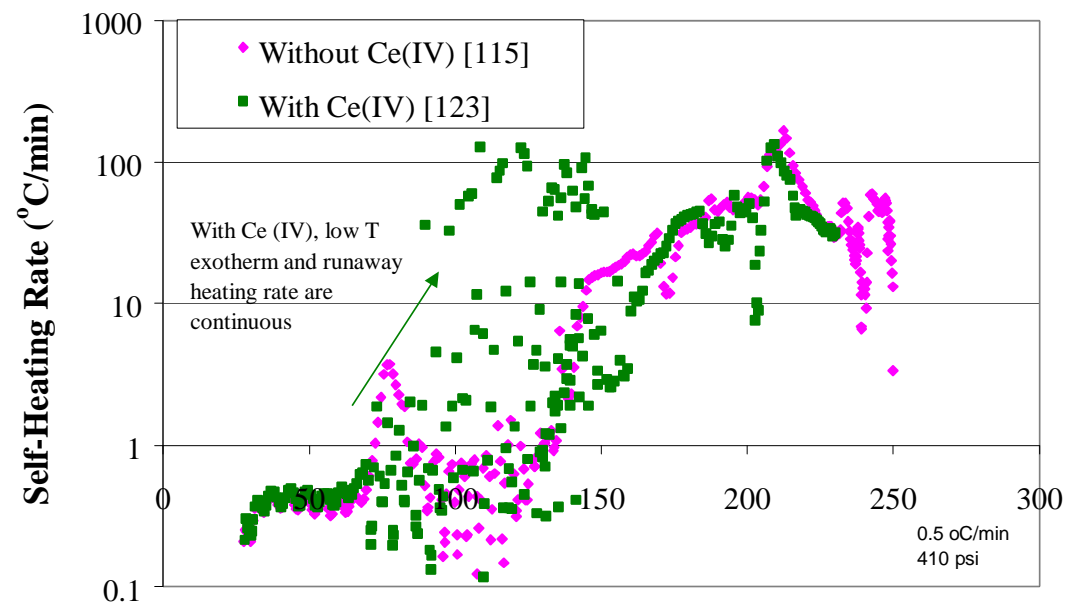

Temperature $\left({ }^{\circ} \mathrm{C}\right)$

Figure 23. RSST Test of the Effect of $\mathrm{Ce}(\mathrm{IV})$ on Reillexf $\mathrm{HPQ}$ in $8 \mathrm{M} \mathrm{HNO}_{3}$ : Self-heating rate $\left({ }^{\circ} \mathrm{C} / \mathrm{min}\right)$ vs. Temperature $\left({ }^{\circ} \mathrm{C}\right)$

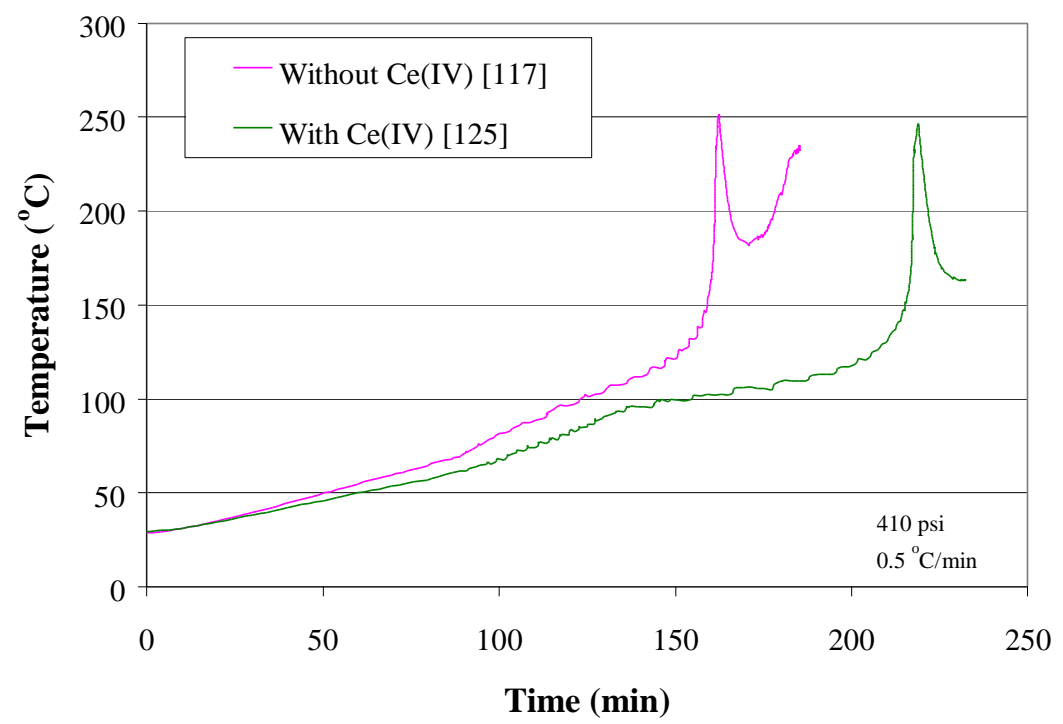

Figure 24. RSST Test of the Effect of $\mathrm{Ce}(\mathrm{IV})$ on Reillexf $\mathrm{HPQ}$ in $12 \mathrm{M} \mathrm{HNO}_{3}$ : Temperature $\left({ }^{\circ} \mathrm{C}\right)$ vs. Time (min) 


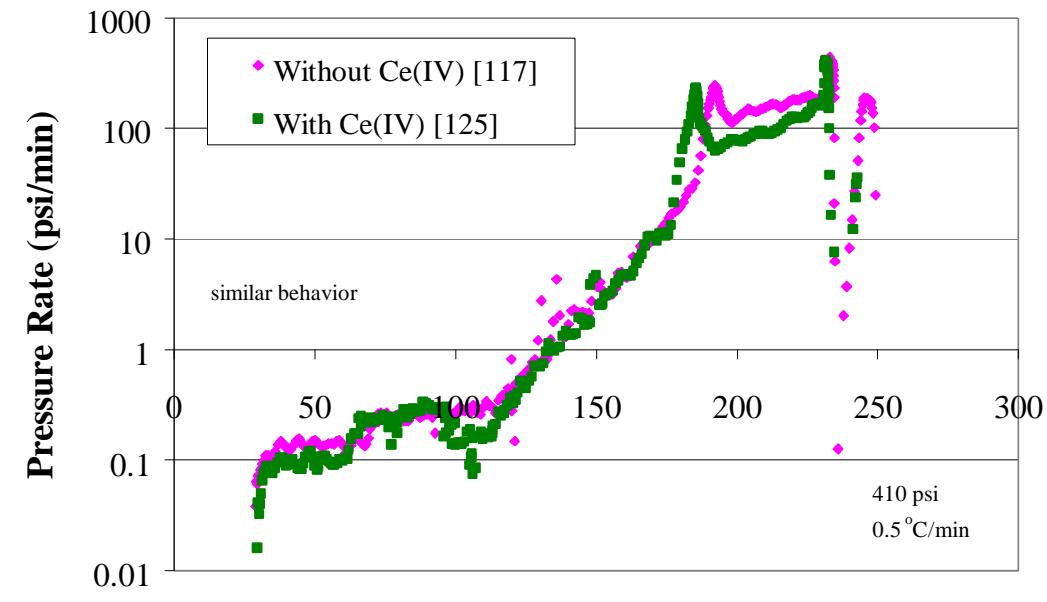

Temperature $\left({ }^{\circ} \mathrm{C}\right)$

Figure 25. RSST Tests of the Effect of Ce(IV) on Reillexf $\mathrm{HPQ}$ in $12 \mathrm{M} \mathrm{HNO}_{3}$ : Pressure Rate (psi/min) vs. Temperature $\left({ }^{\circ} \mathrm{C}\right)$

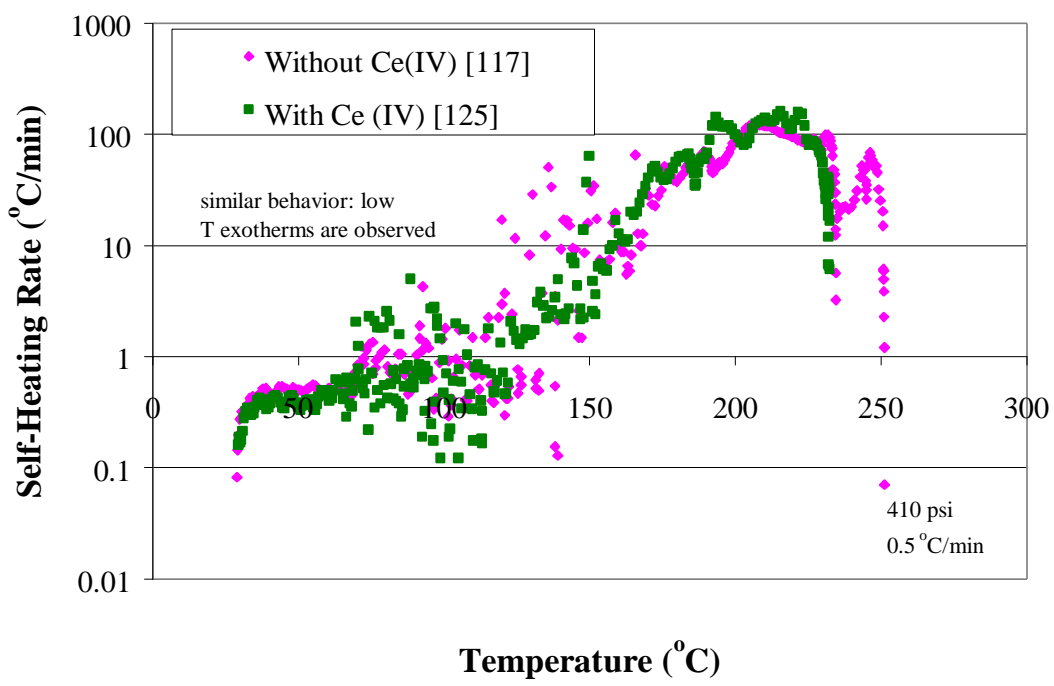

Figure 26. RSST Testsof the Effect of Ce(IV) on Reillexf $\mathrm{HPQ}$ in $12 \mathrm{M} \mathrm{HNO}_{3}$ : Self-heating Rate $\left({ }^{\circ} \mathrm{C} / \mathrm{min}\right)$ vs. Temperature $\left({ }^{\circ} \mathrm{C}\right)$ 


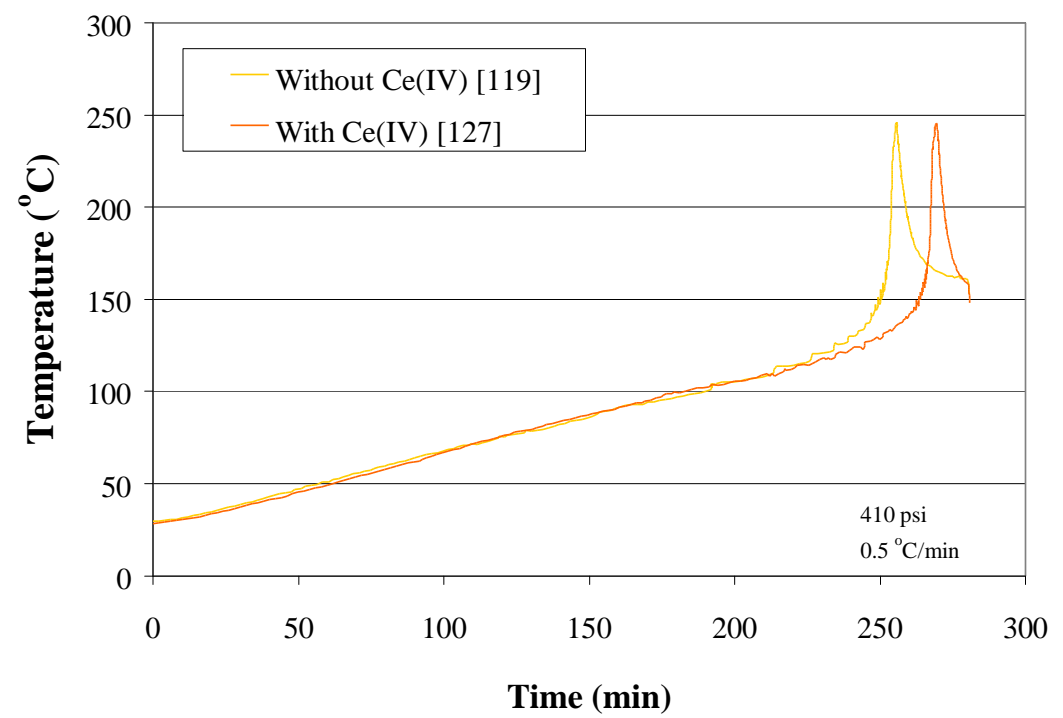

Figure 27. RSST Test of the Effect of Ce(IV) on Irradiated Reillexf $\mathrm{HPQ}$ in $8 \mathrm{M} \mathrm{HNO}_{3}$ : Temperature $\left({ }^{\circ} \mathrm{C}\right)$ vs. Time (min)

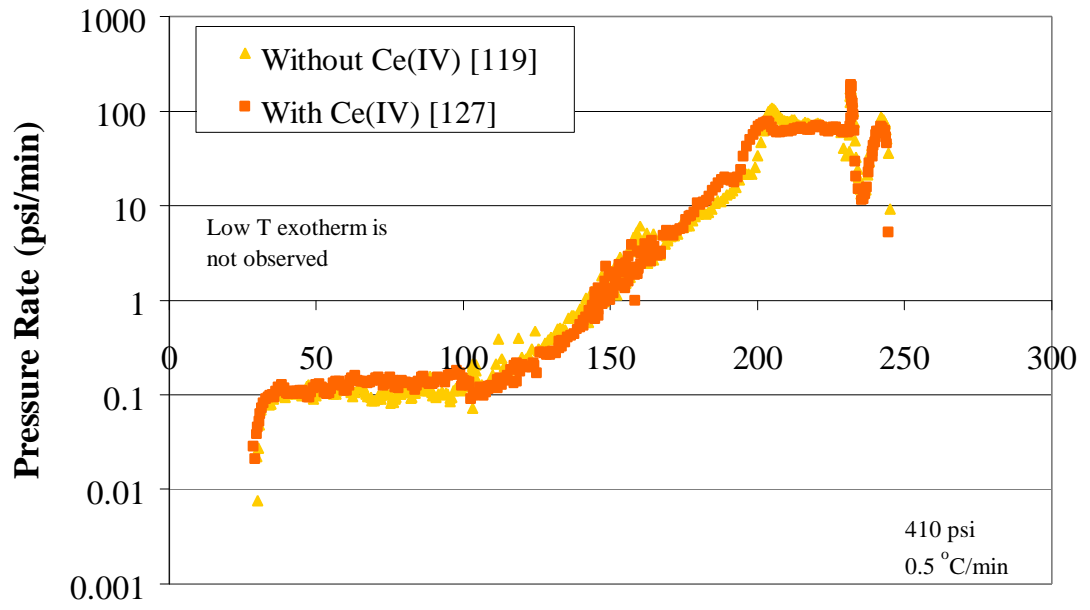

Temperature $\left({ }^{\mathbf{0}} \mathrm{C}\right)$

Figure 28. RSST Test of the Effect of Ce(IV) on Irradiated Reillexf $\mathrm{HPQ}$ in $8 \mathrm{M} \mathrm{HNO}_{3}$ : Pressure Rate (psi/min) vs. Temperature $\left({ }^{\circ} \mathrm{C}\right)$ 


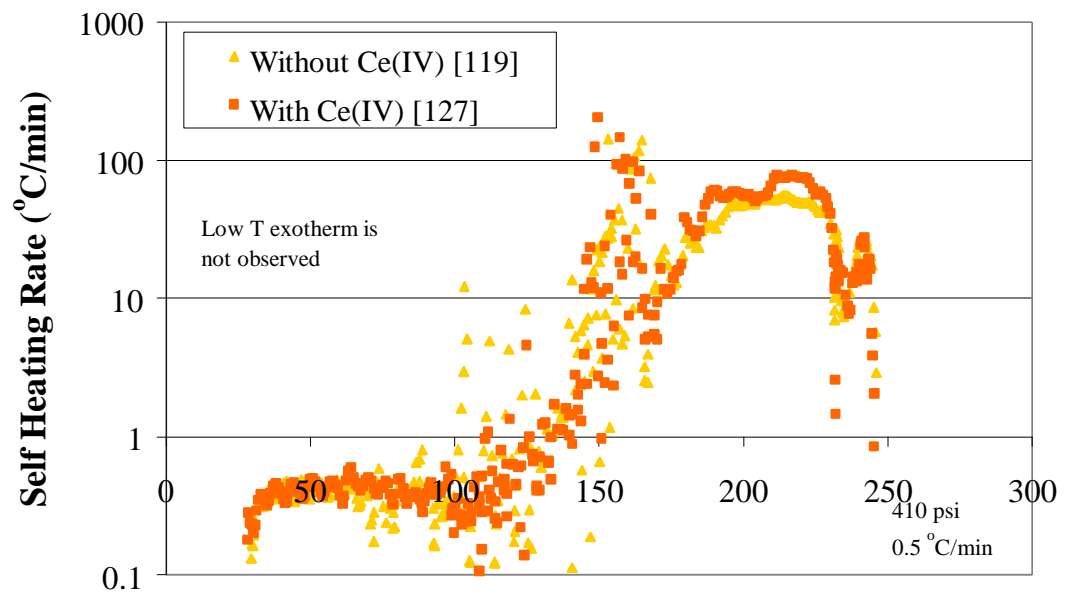

Time (min)

Figure 29. RSST Test of the Effect of $\mathrm{Ce}(\mathrm{IV})$ on Irradiated Reillexf $\mathrm{HPQ}$ in $8 \mathrm{M} \mathrm{HNO}_{3}$ : Self Heating Rate $\left({ }^{\circ} \mathrm{C} / \mathrm{min}\right)$ vs. Temperature $\left({ }^{\circ} \mathrm{C}\right)$

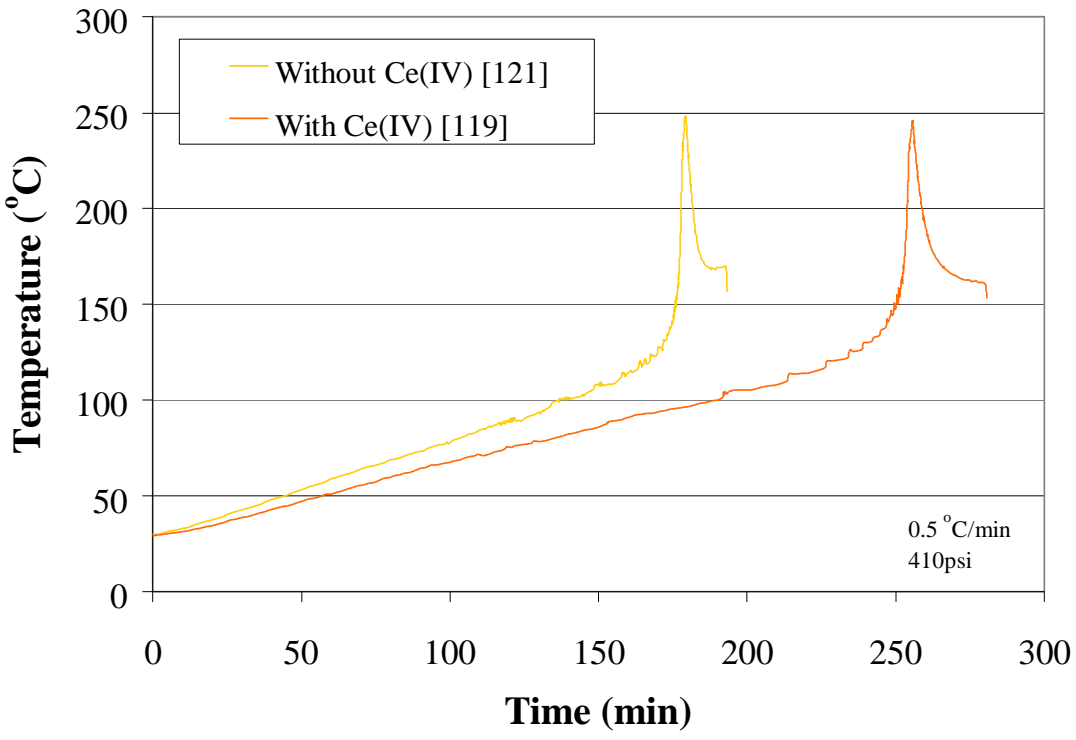

Figure 30. RSST Test of the Effect of Ce(IV) on Irradidated Reillexf $\mathrm{HPQ}$ in $12 \mathrm{M} \mathrm{HNO}_{3}$ : Temperature $\left({ }^{\circ} \mathrm{C}\right)$ vs. Time (min) 


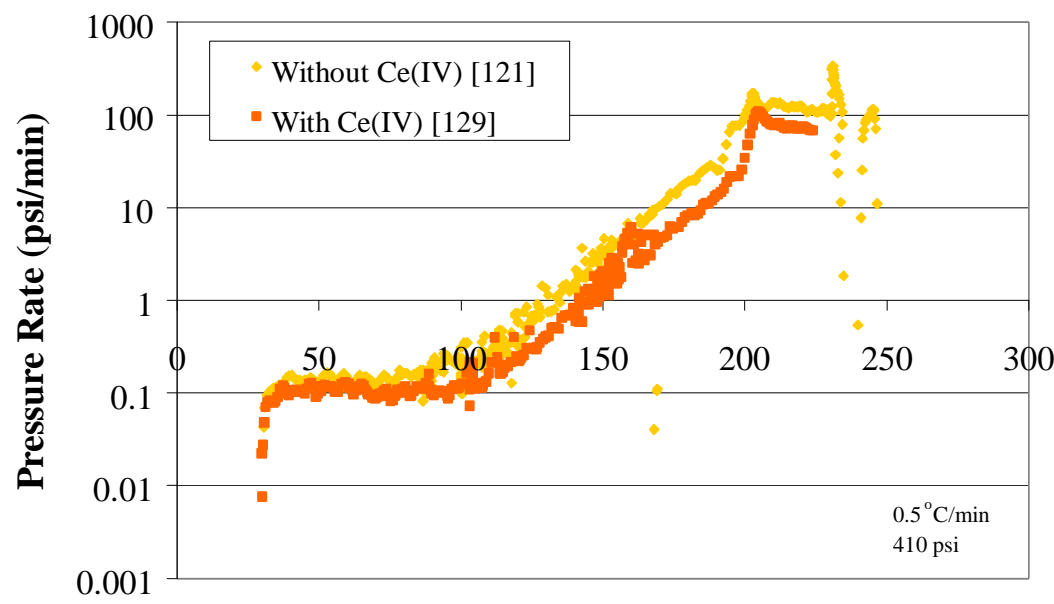

Temperature $\left({ }^{\circ} \mathrm{C}\right)$

Figure 31. RSST Test of the Effect of $\mathrm{Ce}(\mathrm{IV})$ on Irradiated Reillexf in $12 \mathrm{M} \mathrm{HNO}_{3}$ : Presure Rate $\left({ }^{\circ} \mathrm{C} / \mathrm{min}\right)$ vs. Temperature $\left({ }^{\circ} \mathrm{C}\right)$

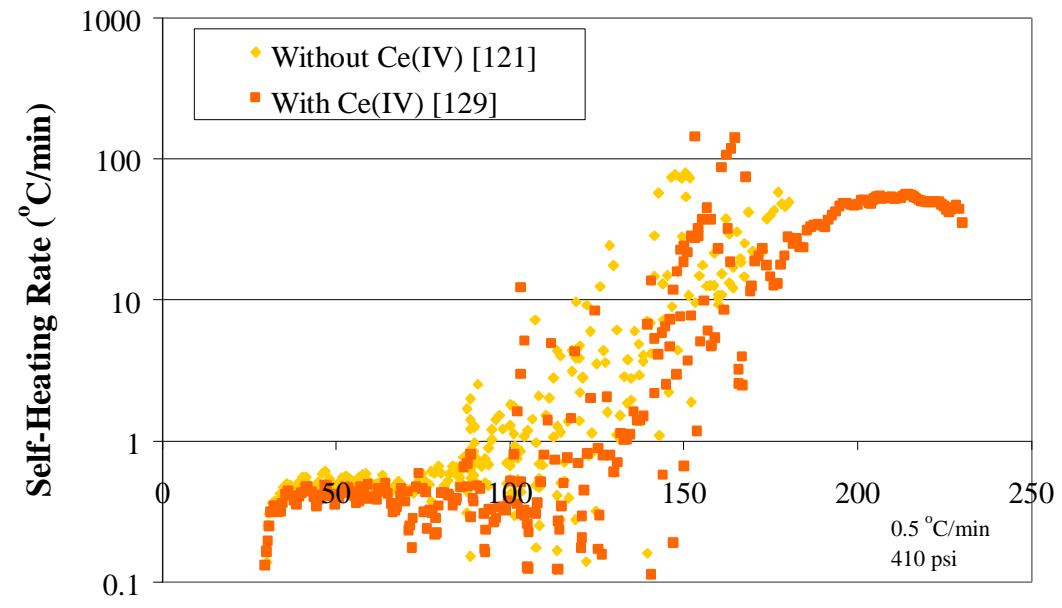

Temperature $\left({ }^{\circ} \mathrm{C}\right)$

Figure 32. RSST Test of the Effect of $\mathrm{Ce}(\mathrm{IV})$ on Irradiated Reillexf in $12 \mathrm{M} \mathrm{HNO}_{3}$ : Self-heating Rate $\left({ }^{\circ} \mathrm{C} / \mathrm{min}\right)$ vs. Temperature $\left({ }^{\circ} \mathrm{C}\right)$ 


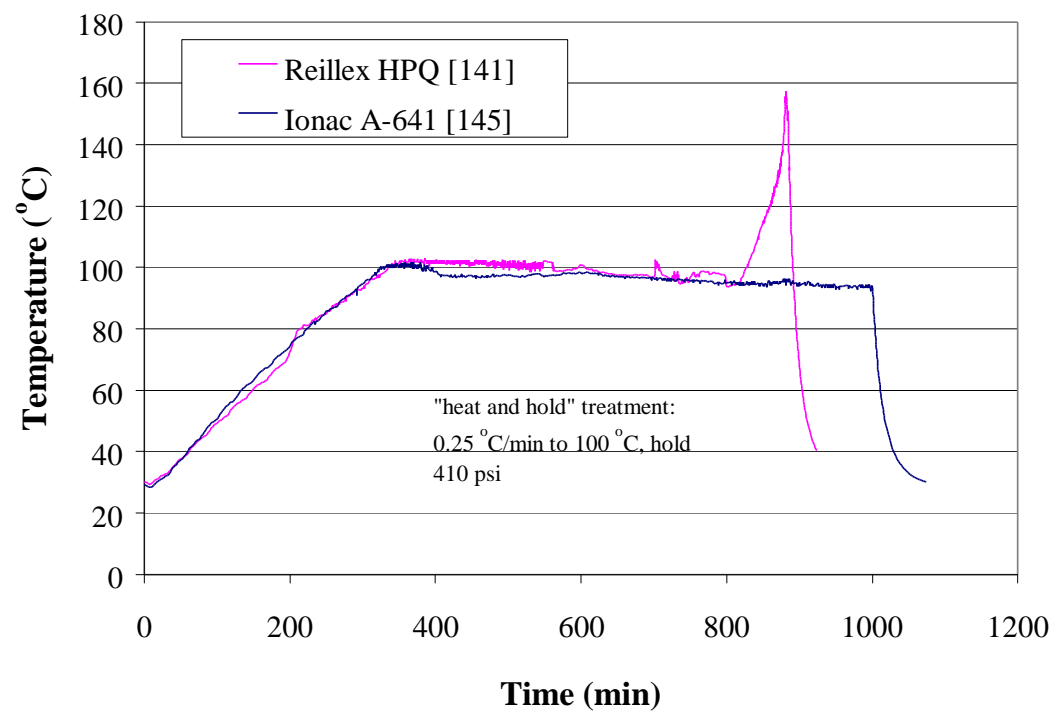

Figure 33. RSST Comparison Test of Resins in $8 \mathrm{M} \mathrm{HNO}_{3}$ at $100{ }^{\circ} \mathrm{C}$ : Temperature $\left({ }^{\circ} \mathrm{C}\right)$ vs Time (min)

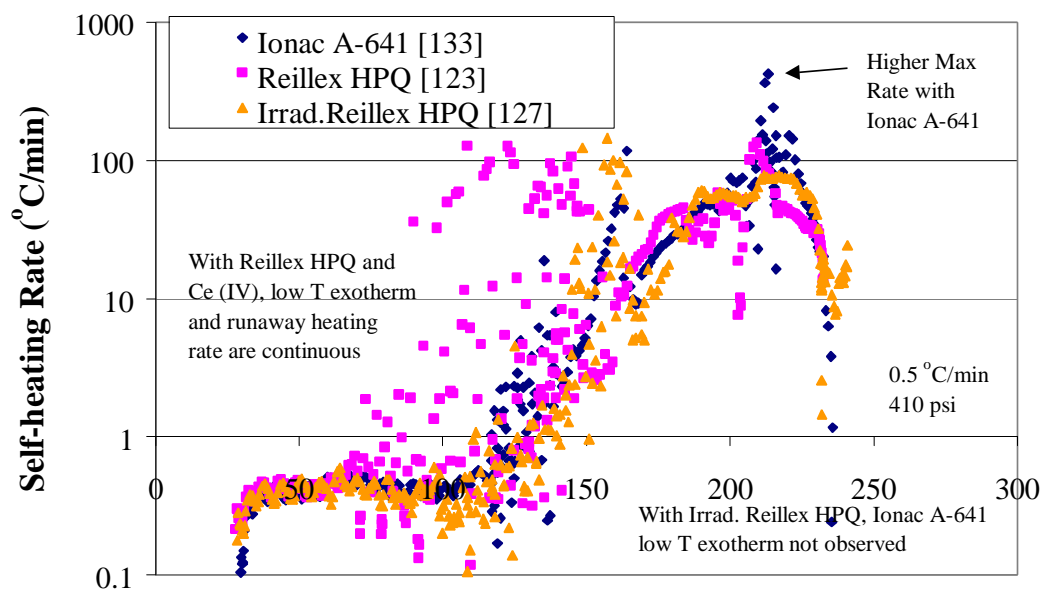

\section{Temperature $\left({ }^{\circ} \mathrm{C}\right)$}

Figure 34. RSST Resin Comparison Test in $8 \mathrm{M} \mathrm{HNO}_{3}$ with $24 \mathrm{~g} / \mathrm{L} \mathrm{Ce}$ (IV): Self-heating Rate $\left({ }^{\circ} \mathrm{C} / \mathrm{min}\right)$ vs. Temperature $\left({ }^{\circ} \mathrm{C}\right)$ 


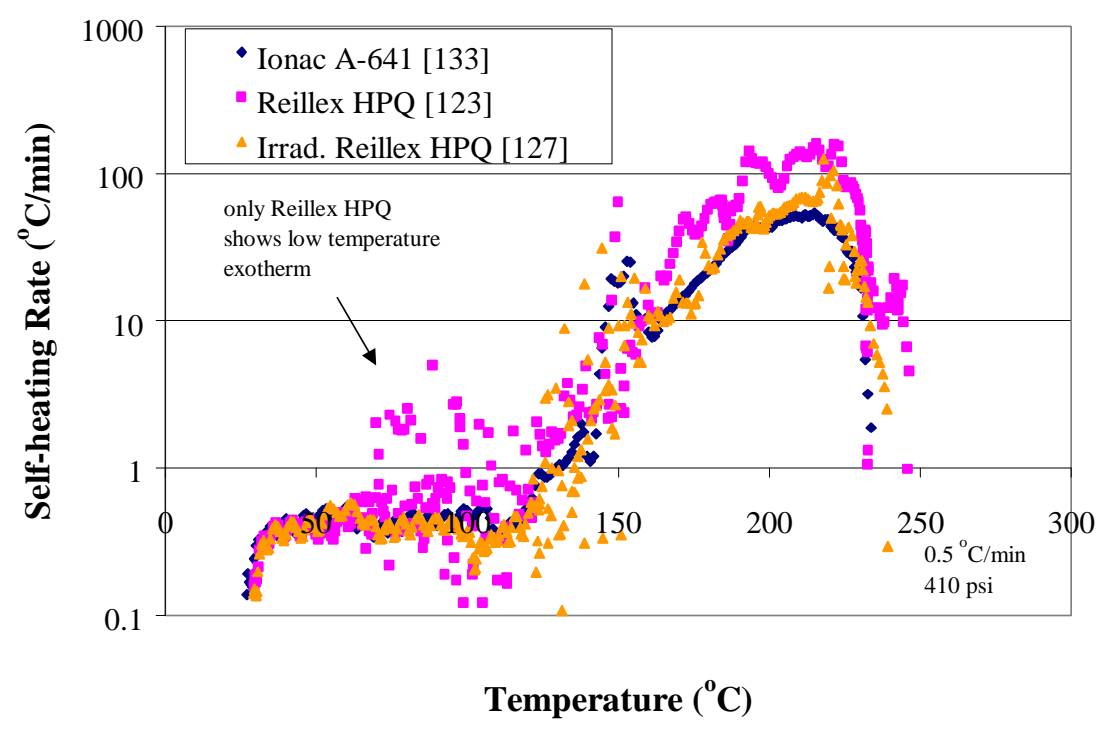

Figure 35. RSST Resin Comparison Test in $12 \mathrm{M} \mathrm{HNO}_{3}, 24 \mathrm{~g} / \mathrm{L}$ Ce (IV): Self-heating Rate $\left({ }^{\circ} \mathrm{C} / \mathrm{min}\right)$ vs. Temperature $\left({ }^{\circ} \mathrm{C}\right)$

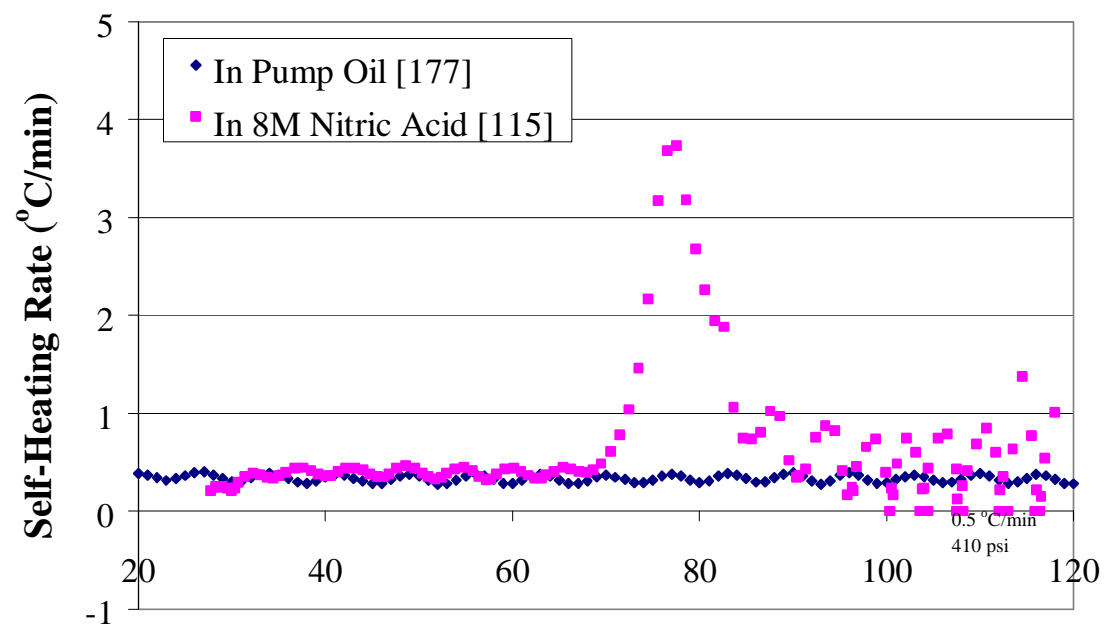

Temperature $\left({ }^{\circ} \mathrm{C}\right)$

Figure 36. RSST Comparison Tests of Reillexf $\mathrm{HPQ}$ Resin in $8 \mathrm{M} \mathrm{HNO}_{3}$ and in Pump Oil: SelfHeating Rate $\left({ }^{\circ} \mathrm{C} / \mathrm{min}\right)$ vs. Temperature $\left({ }^{\circ} \mathrm{C}\right)$ 


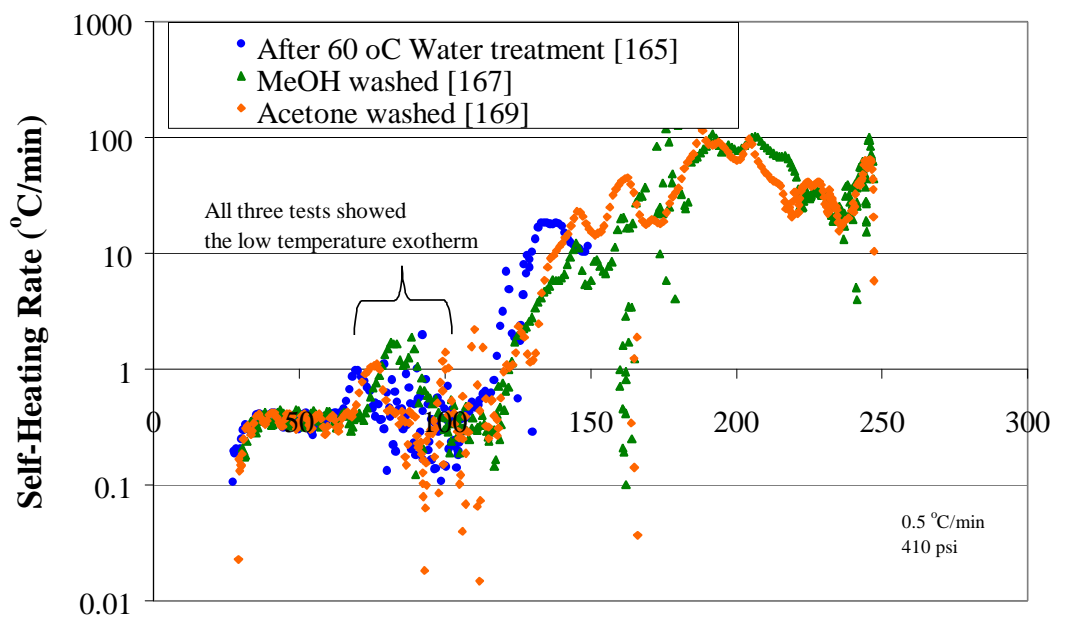

Temperature ( ${ }^{\circ} \mathrm{C}$ )

Figure 37. RSST Tests of Wash-Treated Reillexf $\mathrm{HPQ}$ in $8 \mathrm{M} \mathrm{HNO}_{3}$ : Self-Heating Rate $\left({ }^{\circ} \mathrm{C} / \mathrm{min}\right)$ vs. Temperature $\left({ }^{\circ} \mathrm{C}\right)$

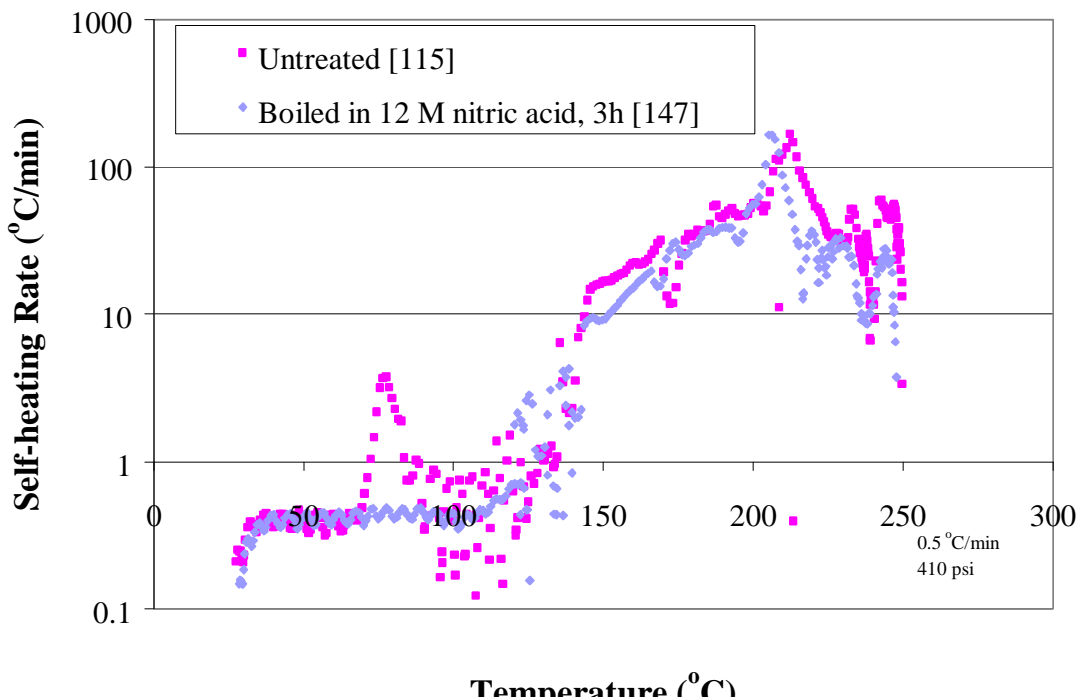

Figure 38. RSST Tests of $12 \mathrm{M} \mathrm{HNO}_{3}$-Treated Reillexf $\mathrm{HPQ}$ in $8 \mathrm{M} \mathrm{HNO}_{3}$ : Self-heating Rate $\left({ }^{\circ} \mathrm{C} / \mathrm{min}\right)$ vs. Temperature $\left({ }^{\circ} \mathrm{C}\right)$ 


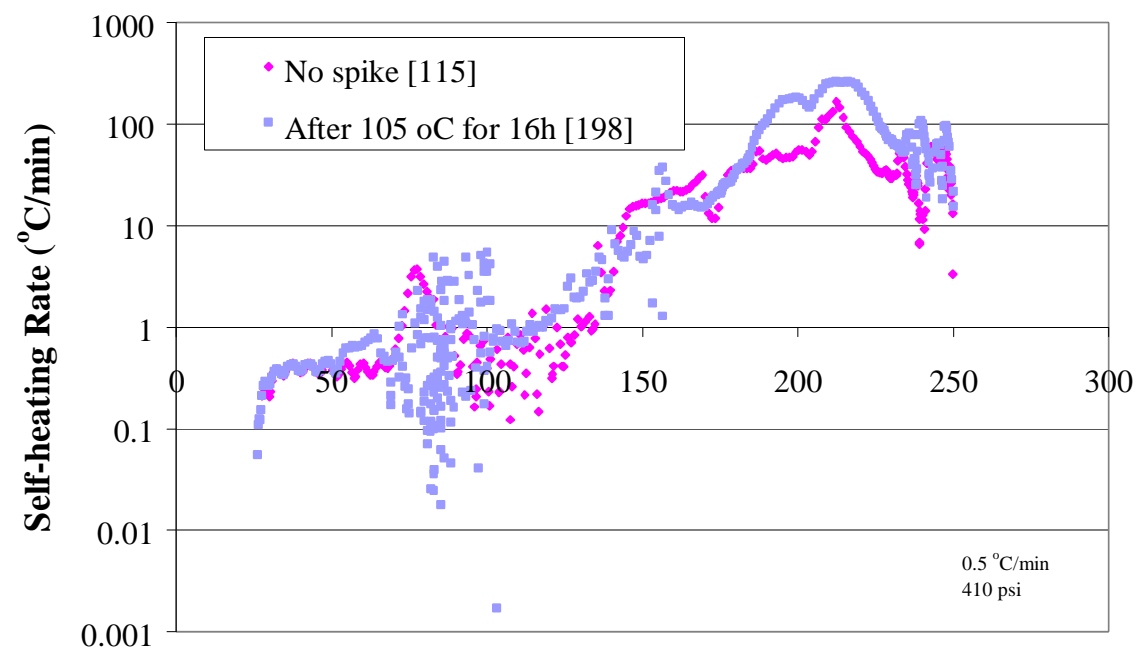

Temperature ( ${ }^{\circ} \mathrm{C}$ )

Figure 39. RSST Test of $12 \mathrm{M} \mathrm{HNO}_{3}$-Treated Reillexf $\mathrm{HPQ}$ in $8 \mathrm{M} \mathrm{HNO}_{3}$ : Self-heating Rate $\left({ }^{\circ} \mathrm{C} / \mathrm{min}\right)$ vs. Temperature $\left({ }^{\circ} \mathrm{C}\right)$

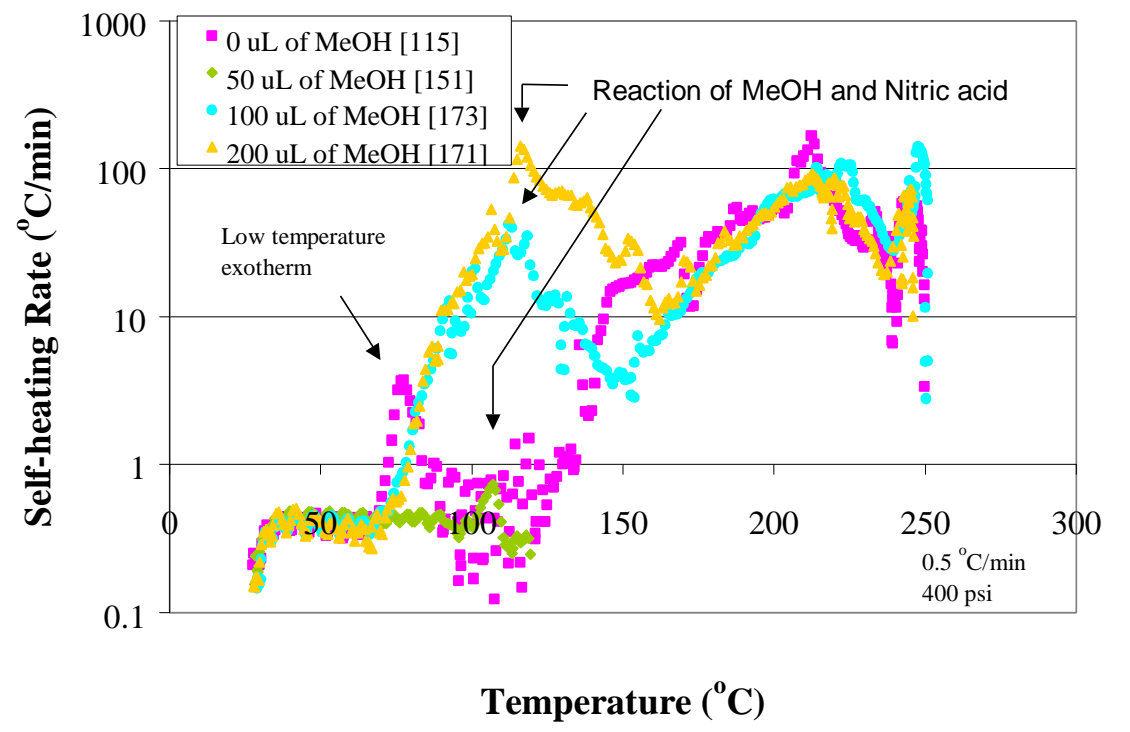

Figure 40. RSST Tests of Reillexf $\mathrm{HPQ}$ in $8 \mathrm{M} \mathrm{HNO}_{3}$ Spiked with MeOH: Self-Heating Rate $\left({ }^{\circ} \mathrm{C} / \mathrm{min}\right)$ vs. Temperature $\left({ }^{\circ} \mathrm{C}\right)$ 


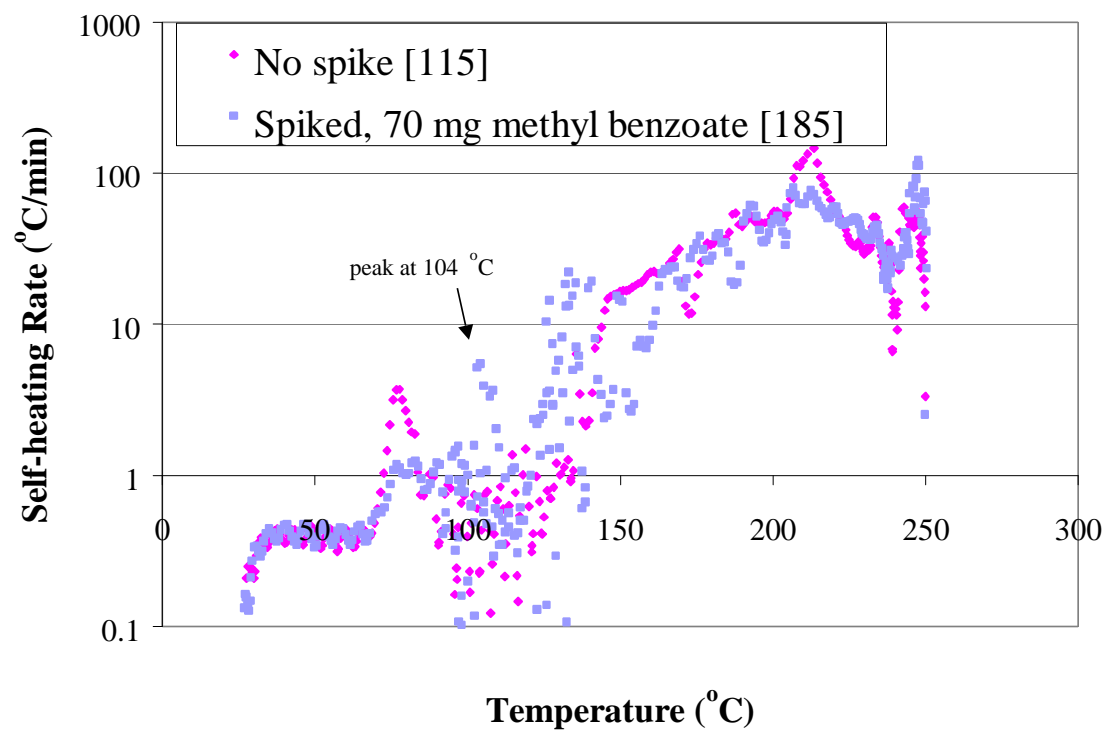

Figure 41. RSST Test of Reillexf $\mathrm{HPQ}$ in $8 \mathrm{M} \mathrm{HNO}_{3}$ Spiked with Methyl Benzoate: Self-heating Rate $\left({ }^{\circ} \mathrm{C} / \mathrm{min}\right)$ vs. Temperature $\left({ }^{\circ} \mathrm{C}\right)$

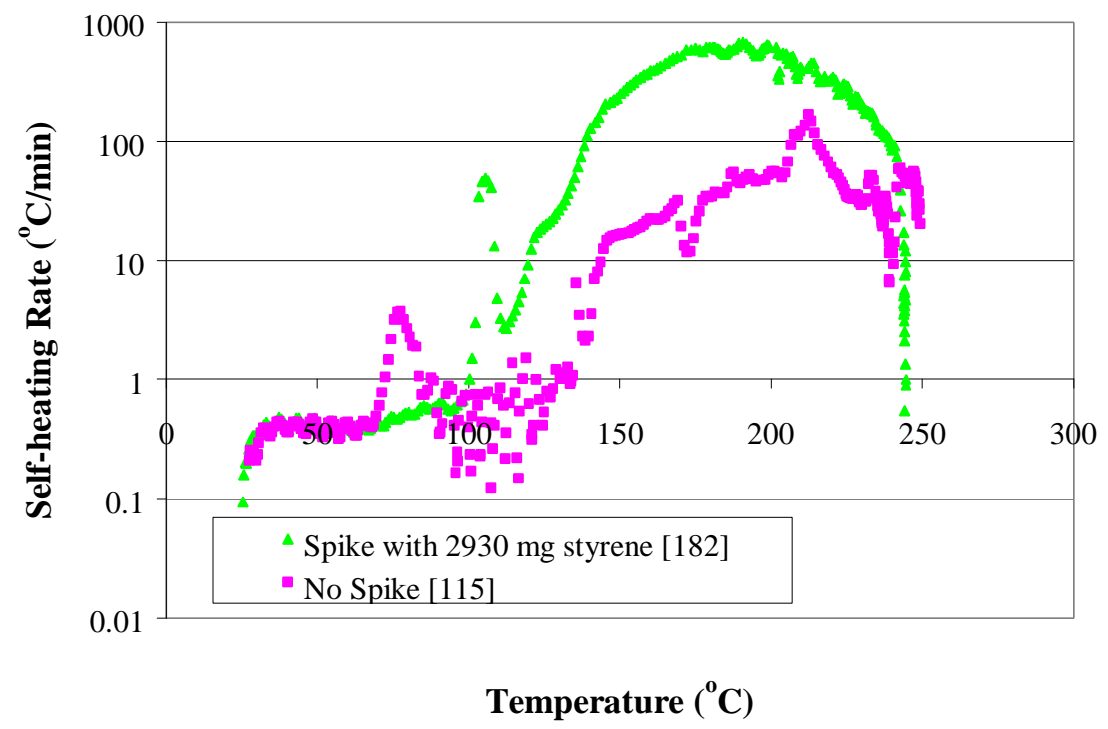

Figure 42. RSST Test of $8 \mathrm{M} \mathrm{HNO}_{3}$ Spiked with Styrene (no resin): Self-heating Rate $\left({ }^{\circ} \mathrm{C} / \mathrm{min}\right)$ vs. Temperature $\left({ }^{\circ} \mathrm{C}\right)$ 


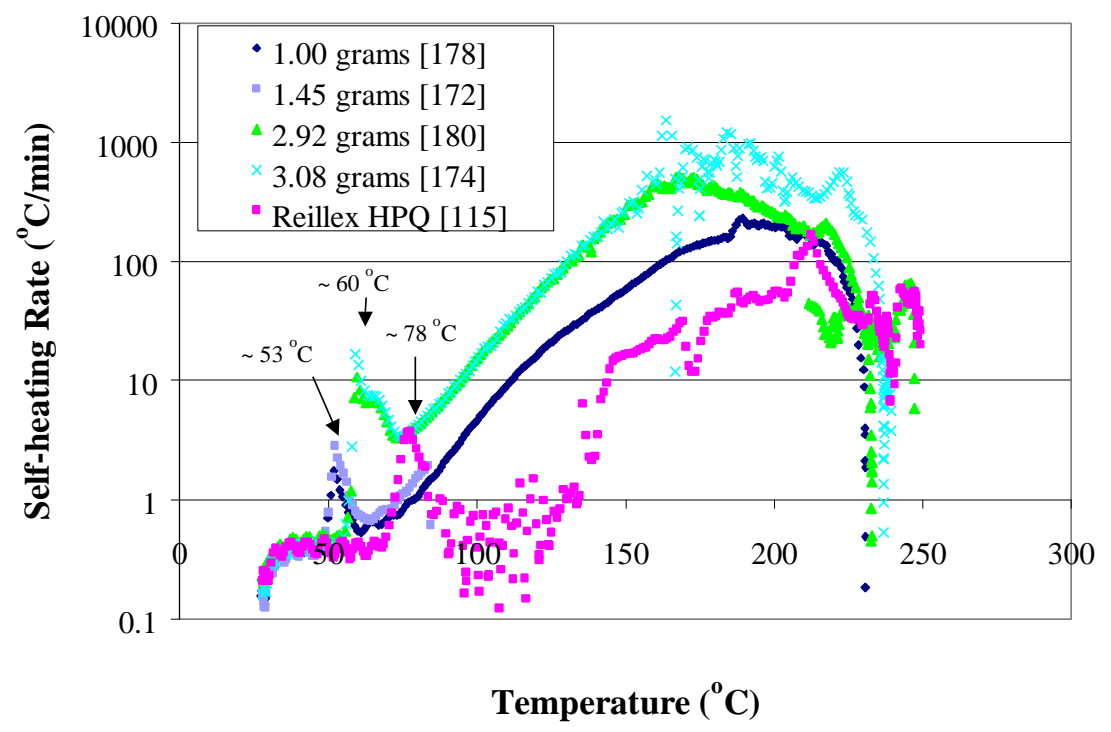

Figure 43. RSST Test of $8 \mathrm{M} \mathrm{HNO}_{3}$ Spiked with Diethylbenzene (no resin): Self-heating Rate $\left({ }^{\circ} \mathrm{C} / \mathrm{min}\right)$ vs. Temperature $\left({ }^{\circ} \mathrm{C}\right)$

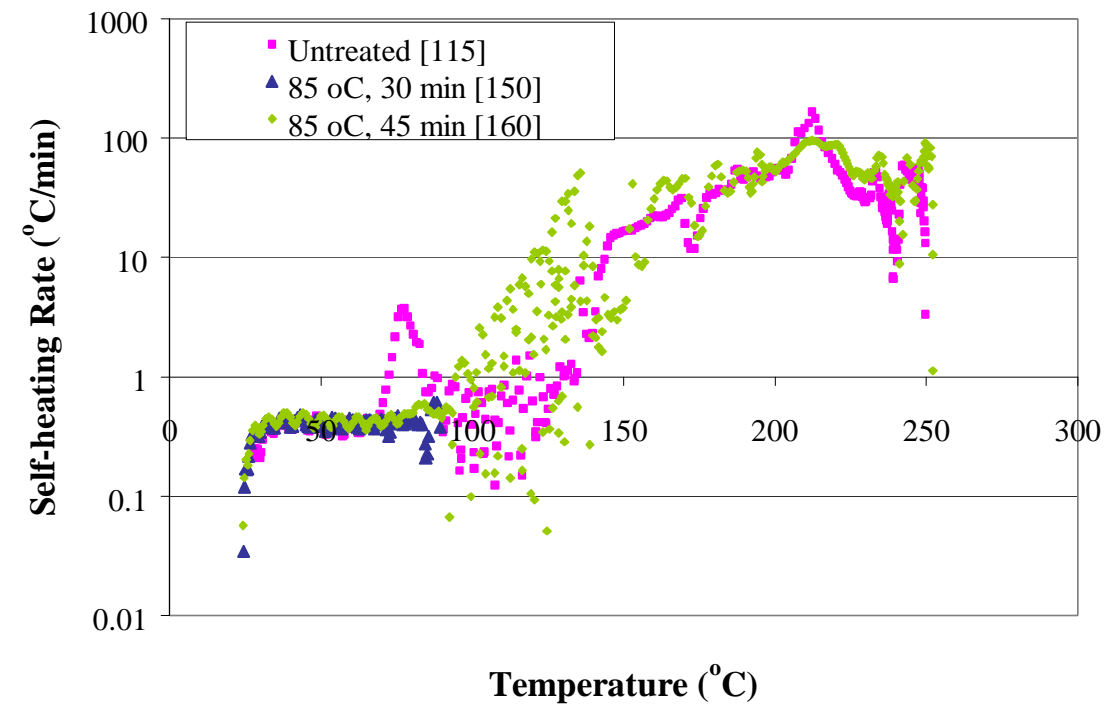

Figure 44. RSST Tests of $8 \mathrm{M} \mathrm{HNO}_{3}$-Treated Reillexf $\mathrm{HPQ}$ in $8 \mathrm{M} \mathrm{HNO}_{3}$ : Self-heating Rate $\left({ }^{\circ} \mathrm{C} / \mathrm{min}\right)$ vs. Temperature $\left({ }^{\circ} \mathrm{C}\right)$ 


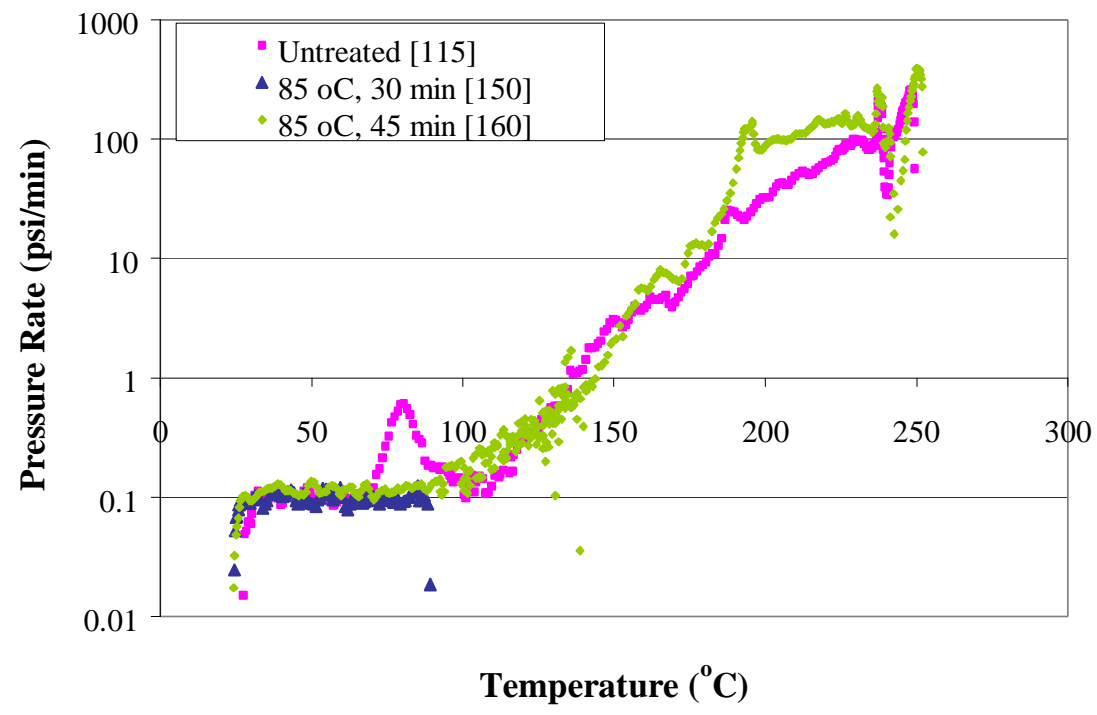

Figure 45. RSST Tests of $8 \mathrm{M} \mathrm{HNO}_{3}$-Treated Reillexf $\mathrm{HPQ}$ in $8 \mathrm{M} \mathrm{HNO}_{3}$ : Pressure Rate (psi/min) vs. Temperature $\left({ }^{\circ} \mathrm{C}\right)$

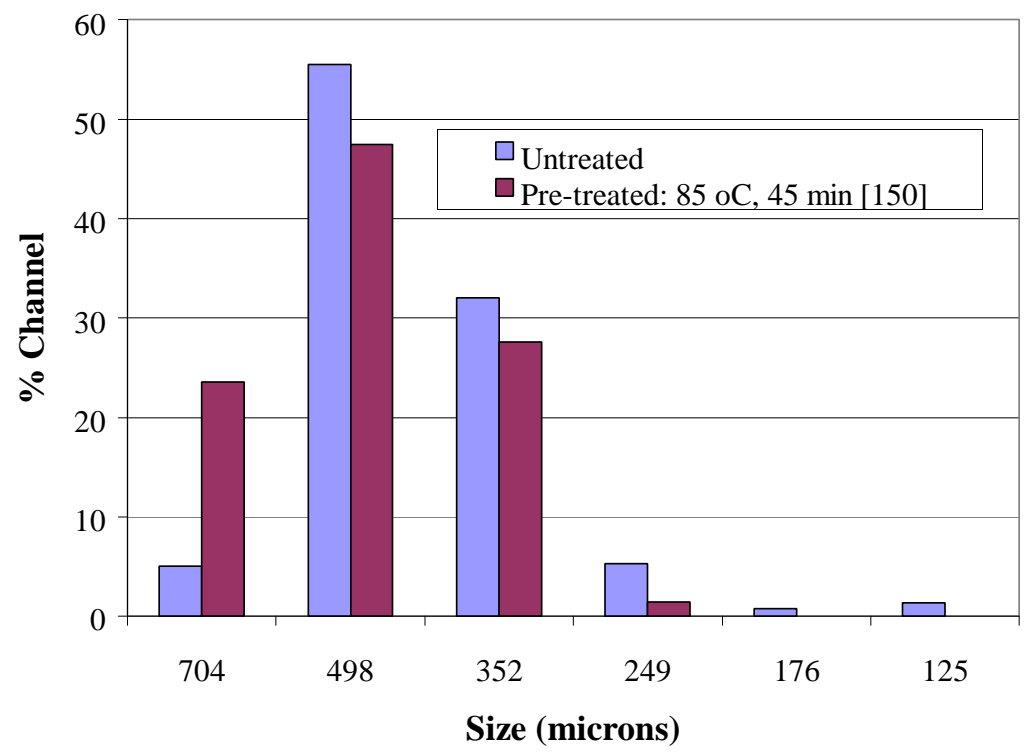

Figure 46. Particle Size Distribution of Reillexf HPQ: Untreated vs. $8 \mathrm{M} \mathrm{HNO}_{3}$-Treated (45 min) 